\title{
Site U1316
}

\author{
Expedition 307 Scientists $^{2}$
}

\section{Chapter contents}

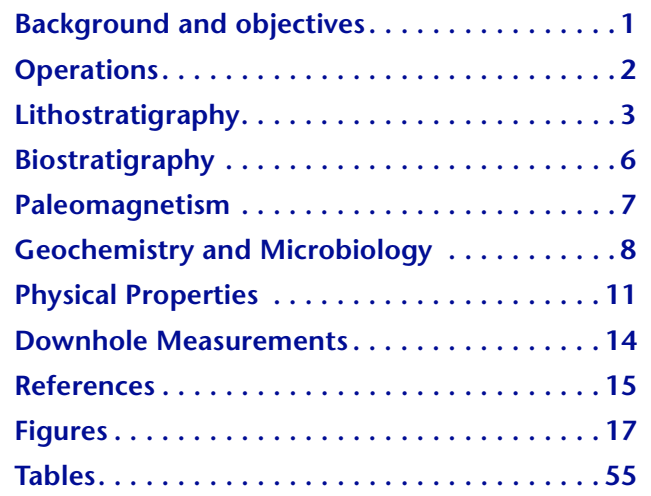

'Expedition 307 Scientists, 2006. Site U1316. In Ferdelman, T.G., Kano, A., Williams, T., Henriet, J.-P., and the Expedition 307 Scientists. Proc. IODP, 307: Washington, DC (Integrated Ocean Drilling Program Management International, Inc.). doi:10.2204/ iodp.proc.307.103.2006

2Expedition 307 Scientists' addresses.

\section{Background and objectives}

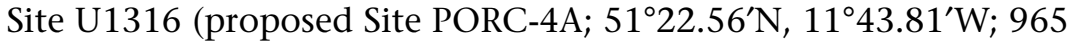
$\mathrm{m}$ water depth) is located in the downslope sediment deposits $\sim 700 \mathrm{~m}$ southwest of Challenger Mound (Fig. F1). Challenger Mound is part of the Belgica mound province of outcropping and buried carbonate mounds on the eastern slope of Porcupine Seabight on the southwest continental margin of Ireland. Surface sediments at Site U1316 consist of rippled sands littered with dropstones (Foubert et al., 2005) and attest to the northwardflowing bottom currents that have kept the western flank of Challenger Mound free of sediments (Van Rooij et al., 2003). Shallow piston coring at Site U1316 (Marion Dufresne Core MD01-2450) recovered $12 \mathrm{~m}$ of silty clay with common to abundant nannofossils. Fine to medium sandy intercalations and a few centimeterscale silty layers are present between the silty clays. Based on the seismic distribution and the sedimentological parameters, this interval is interpreted as drift sediments. The presence of a turbidite layer is evidence of a complex sedimentological environment with combined bottom and downslope sedimentological processes on the southwest flank of Challenger Mound. Glacialinterglacial variations have been identified in the sedimentological record (Foubert et al., 2005). Interglacial deposits are characterized by coarser grain fractions, indicating a more intensive current regime than in glacial periods. It is suggested that the inflow of Mediterranean Outflow Water in the basin during interglacial periods enhanced the current regime. Ice-rafted events in the glacial sediments record sediment delivery from both the Laurentide Ice Sheet and British-Irish Ice Sheet (Foubert et al., 2005).

Three main seismostratigraphic units can be identified in the Belgica mound area, separated by two regional discontinuities (Van Rooij et al., 2003) (see Fig. F3 in the "Expedition 307 summary" chapter). The lowermost Unit P1 is characterized by gentle, basinward-dipping continuous parallel strata with moderate to locally high amplitude reflectors. A clinoform pattern formed by a number of superimposed sigmoid reflectors is encountered in the upper strata of Unit P1 below and adjacent to Challenger Mound (Fig. F2). These clinoforms are frequently characterized by a highamplitude top sigmoid reflector. This seismic facies is interpreted as migrating drift bodies (Van Rooij et al., 2003; De Mol et al., 2005). The upper boundary of Unit P1 is an erosional unconformity which strongly incises the underlying strata. Unit P2 is characterized by a nearly transparent acoustic facies on top of the erosional unconformity bounding Units P1 and P2. Only a few sets 
of continuous relatively high amplitude reflectors are observed inside Unit P2. The uppermost seismic Unit P3, characterized by slightly upslope migrating wavy parallel reflectors, represents Quaternary drift deposits partly enclosing the mounds. The reflectors of Unit P3 onlap the mound, demonstrating that the mounds were already present before the deposition of the most recent drift. Scouring and moat features around the mounds suggest that the mounds had obtained a significant dimension and affected the intensity of the currents and the deposition of the enclosing sediments. Only seismic Units P1 and P3 are encountered at Site U1316 adjacent to Challenger Mound and are separated by a regional erosional unconformity interpreted as the mound base (Fig. F2).

The principal objectives at Site U1316 were as follows:

1. Gain insight into the history of drift deposits on the downslope flank of Challenger Mound and the off-mound transport of mound-related skeletal and nonskeletal grains. Because of the close proximity of the site to Challenger Mound, the Quaternary deposits at Site U1316 should yield information on development of the mound itself as well as the depositional history of the mound environment, particularly coral-shedding events. Furthermore, they will provide full information on the genesis of seismic Unit P3 and records of high-frequency ice-rafting episodes.

2. Investigate the character and age of the sigmoid units observed in the upper part of seismic Unit P1 that appears to form the substratum of Challenger Mound. These units, characterized by a high-amplitude sigmoid top reflector, may indicate a possible microreservoir of shallow gas or be the result of a past fluid expulsion event. Therefore, the sediments in these lenticular bodies might provide clues to a past geofluid migration event and past microbial activity leading to mound initiation. Alternatively, the acoustic character of the sigmoid clinoforms might be related to the presence of coarse-grained sediments expected in high-energy drift deposits or a change in lithology in combination with the geometric effect.

3. Evaluate whether the sigmoid-shaped units contain high concentrations of gas and thus represent a potential hazard for drilling in Challenger Mound. Further drilling of Challenger Mound (Site U1317) was made contingent on investigation of the sediments along its flank at Site U1316.

\section{Operations}

The 302 nmi transit from Dublin, Ireland, to Site U1316 was accomplished at an average speed of 9.7 kt in just under $32 \mathrm{~h}$. During the transit, drilling and coring equipment was prepared.

\section{Hole U1316A}

Once on site, the thrusters were lowered and the vessel was placed in dynamic positioning mode. The hydrophones were lowered and the positioning beacon was deployed at $0410 \mathrm{~h}$ on 30 April 2005, officially marking the beginning of on-site operations. The precision depth recorder provided a seafloor depth of $956.4 \mathrm{~m}$, corrected to the rig floor dual elevator stool. The drill string deployment for Hole U1316A was initiated by picking up drill collars and strapping (measuring) and drifting (verifying minimum internal bore diameter) all tubular components. A two-stand advanced piston corer (APC)/extended core barrel (XCB) bottom-hole assembly (BHA) was used for coring. After tripping the drill string to bottom, the top drive was picked up and the drill string was spaced out for spudding. Hole U1316A was spudded with the APC at $1120 \mathrm{~h}$ on 30 April, and a seafloor depth of 959.2 meters below rig floor (mbrf) was established.

Eight APC cores advanced to 66.3 meters below seafloor (mbsf) (1025.5 mbrf; recovery $=95 \%)$. APC temperature measurements were taken at 26.3 and $54.8 \mathrm{mbsf}$, and the Tensor orientation tool took measurements from 26.3 to $64.3 \mathrm{mbsf}$. Core $8 \mathrm{H}$ shortstroked and became stuck at $66.3 \mathrm{mbsf}$, and a maximum of $80 \mathrm{klb}$ overpull was not able to free it. The core barrel was released after overdrilling $1.5 \mathrm{~m}$. The coring assembly was switched to XCB, and $13 \mathrm{XCB}$ cores advanced an additional $67.7 \mathrm{~m}$ to a total depth (TD) of 134.0 mbsf (1093.2 mbrf; recovery $=80 \%)$. $\mathrm{XCB}$ coring times were long and recovery erratic. The XCB coring shoe on Core $18 \mathrm{X}$ failed in torsion but remained on the core barrel, and heat checking was evident on other coring shoes. The average penetration rate was $<3 \mathrm{~m} / \mathrm{h}$. Coring was suspended at $2015 \mathrm{~h}$ on 1 May because of the slow penetration rate.

Hole U1316A was prepared for logging. A wiper trip was run from bottom up to $30 \mathrm{mbsf}$ and back to bottom using the top drive, fill $(1 \mathrm{~m})$ was circulated out, and the hole was displaced with $45 \mathrm{bbl}$ of sepiolite mud. The bit was then pulled up to logging depth of 30 mbsf.

The Schlumberger wireline logging sheaves were rigged up, and the triple combination (triple combo) tool string was assembled and deployed. On the way into the open hole it encountered an obstruction at $45 \mathrm{mbsf}$, which left $5 \mathrm{~m}$ of the logging string still inside the drill pipe. The logging string was picked up and run back down but would not pass beyond 30 
mbsf, which was coincident with the lockable float valve. It was speculated that vessel heave and the shallow engagement of the drill pipe in the hole (30 $\mathrm{m})$ allowed the pipe to "walk around" and wallow out the top of the hole. The logging program was suspended and the tools recovered. The Schlumberger logging sheaves were rigged down and the drill string was pulled clear of the seafloor at $0640 \mathrm{~h}$ on 2 May, officially ending operations in Hole U1316A.

\section{Hole U1316B}

The drillship was offset $20 \mathrm{~m}$ north of Hole U1316A, and the drill string was spaced out for spudding. Hole U1316B was spudded with the APC at $0830 \mathrm{~h}$ on 2 May 2005, and a seafloor depth of 959.0 mbrf was established.

Eight APC cores advanced to a TD of $59.5 \mathrm{mbsf}$ $(1018.5$ mbrf; recovery $=103 \%)$. Perfluorocarbon tracer (PFT) and microsphere tracers were run on all cores, and the Tensor orientation tool took measurements from 24.5 to 59.5 mbsf. The drill string was pulled clear of the seafloor at $1500 \mathrm{~h}$ on 2 May, officially ending operations in Hole U1316B.

\section{Hole U1316C}

Note: Hole U1316C was drilled out of sequence to take advantage of the logistics of APC/XCB coring at nearby Site U1317. After completing Hole U1316B, the ship moved to Site U1317, where we cored three $\mathrm{APC} / \mathrm{XCB}$ holes and changed out the BHA from APC/ $\mathrm{XCB}$ to rotary core barrel (RCB) to core Hole U1317D.

The ship moved back to Site U1316 from Site U1317 on 7 May 2005. The location coordinates for Hole $1316 \mathrm{C}$ were $20 \mathrm{~m}$ south-southeast of Hole U1316A. The RCB BHA was made up with a mechanical bit release (MBR) and three stands of drill collars. Hole U1316C was spudded at $0800 \mathrm{~h}$ on 7 May, and seafloor was established at 959.0 mbrf. The RCB was initially run with a center bit and the hole was drilled ahead to 40.0 mbsf (999.0 mbrf). The center bit was retrieved and $11 \mathrm{RCB}$ cores advanced an additional $103.1 \mathrm{~m}$ to a TD of $143.1 \mathrm{mbsf}$ (1102.1 mbrf) at 0010 h on 8 May (recovery $=68 \%$ ). PFT and microsphere tracers were run on all cores.

Hole U1316C was prepared for logging. A wiper trip was run from bottom up to 58 mbsf and back to bottom. There was no fill. The RCB bit was released by a wireline releasing tool and dropped to the bottom. The hole was displaced with $44 \mathrm{bbl}$ of sepiolite mud, and the drill pipe was tripped to the logging depth of 59 mbsf.
The Schlumberger wireline logging sheaves were rigged up, and the triple combo tool string was assembled. The logging string was run in the hole to TD at 143 mbsf and logged uphole. After a single pass, the tools were pulled out of the hole and laid out at $0715 \mathrm{~h}$ on 8 May.

The second logging run was with the Formation MicroScanner (FMS)-sonic tool string. The FMS-sonic tool string was assembled and run to bottom. Two logging passes were made from bottom to $59 \mathrm{mbsf}$. With logging complete, the string was pulled out of the hole and laid out at $1135 \mathrm{~h}$ on 8 May. The Schlumberger wireline logging sheaves were rigged down, ending the logging operation at $1330 \mathrm{~h}$ on 8 May.

The drill pipe was tripped to the surface, the beacon was released at $1350 \mathrm{~h}$ and recovered, and the MBR cleared the rotary at $1515 \mathrm{~h}$ on 8 May, ending operations at Site U1316 (Table T1).

\section{Lithostratigraphy}

The lithology at Site U1316 can be divided into three main lithostratigraphic units based on visual descriptions of Hole U1316A (Fig. F3). Unit 1 is Pleistocene, Unit 2 is late Pliocene-Pleistocene, and Unit 3 is early-middle Miocene in age. Each unit is further divided into two subunits. Typical lithology of each subunit is shown in Figure F4. The major boundaries and lithostratigraphic units defined in Hole U1316A can also be applied to Holes U1316B and U1316C. The differentiation into units is based on sediment composition and age, as well as color reflectance and natural gamma radiation (Fig. F3). A major unconformity located between Units 2 and 3 is recognized at 55.0, 58.3, and $51.5 \mathrm{mbsf}$ in Holes U1316A, U1316B, and U1316C, respectively, and separates the upper Pliocene-Pleistocene from the underlying lower-middle Miocene sediments.

\section{Unit 1}

Intervals: Sections 307-U1316A-1H-1, $0.0 \mathrm{~cm}$, through 5H-4, $85 \mathrm{~cm}$; and 307-U1316B-1H-1, $0.0 \mathrm{~cm}$, through $6 \mathrm{H}-2,70 \mathrm{~cm}$

Depths: Hole U1316A: 0.0-44.40 mbsf and Hole U1316B: 0.0-45.20 mbsf

Age: $<0.26 \mathrm{Ma}$; Pleistocene (by first-appearance datum [FAD] of Emiliania huxleyi)

Unit 1 is divided into two subunits by a distinct erosive boundary (Fig. F5). The following core description is based on Hole U1316A unless noted otherwise. 


\section{Subunit 1A}

Intervals: Sections 307-U1316A-1H-1, $0.0 \mathrm{~cm}$, through 3H-3, $5 \mathrm{~cm}$; and 307-U1316B-1H-1, $0.0 \mathrm{~cm}$, through $4 \mathrm{H}-2,28 \mathrm{~cm}$

Depths: Hole U1316A: 0.0-25.90 mbsf and Hole U1316B: 0.0-26.30 mbsf

Age: $<0.26 \mathrm{Ma}$ (by FAD of E. huxleyi)

Subunit $1 \mathrm{~A}$ is dominated by mottled grayish brown to dark grayish green silty clay to clayey silt. The sediments are partly interbedded with centimeter-thick fine-sand layers that occasionally grade upward. Bioturbation rarely occurs in this subunit and appears as round fine-sand lenses. Dropstones occur frequently. Fossils are generally rare and quite dispersed. At 5.90 mbsf, a very thin shell debris layer occurs. The base of Subunit $1 \mathrm{~A}$ is defined by an erosive boundary overlain by a $12 \mathrm{~cm}$ thick, graded medium- to finesand layer with up to centimeter-sized lithoclasts at the base. The same sedimentary package corresponds to a soft-sediment disturbance structure overlain by a medium-sand layer grading into clayey silt in Hole U1316B at 26.30 mbsf (Sample 307-U1316B-4H-2, 28 cm) (Fig. F5).

\section{Subunit 1B}

Intervals: Sections 307-U1316A-3H-3, $5 \mathrm{~cm}$, through 5H-6, $115 \mathrm{~cm}$; and 307-U1316B-4H$2,28 \mathrm{~cm}$, through $6 \mathrm{H}-2,70 \mathrm{~cm}$

Depths: Hole U1316A: 25.90-44.40 mbsf and Hole U1316B: $26.30-45.20 \mathrm{mbsf}$

Age: $<0.26 \mathrm{Ma}$ (by FAD of E. huxleyi)

Subunit $1 \mathrm{~B}$ is characterized by laminated very dark olive-gray to dark gray silty clay interbedded with fine-sand layers (Fig. F4). Lamination thickness varies from millimeter to centimeter scale. Mottled intervals are generally rare. Dropstones occur frequently and are limited to discrete intervals. At 41.00 mbsf, a mixture of silty clay layers with a calcareous fine to medium sand forms a $20 \mathrm{~cm}$ thick soft-sediment deformation structure possibly indicating slumping (Fig. F6). The deformation feature also appears in Hole U1316B as a $10 \mathrm{~cm}$ thick bed of poorly sorted medium sand that grades upward into clayey silt (Sample 307-U1316B-5H-6, 90 cm; 42.90 mbsf). Just above this layer, a medium-sand to finegravel layer is observed consisting of a mixture of dropstones, coral fragments of Lophelia pertusa, and other bioclasts (interval 307-U1316A-5H-4, 55-63 $\mathrm{cm})$ (Fig. F6). This distinctive bed is correlated with a lithologically similar layer in interval 307-U1316B$5 \mathrm{H}-6,55-64 \mathrm{~cm}$.

The base of Subunit 1B is defined by an erosive unconformity overlain by a fining-upward sequence of graded fine to very fine sand beds about $1 \mathrm{~m}$ and 70 cm thick in Holes U1316A and U1316B, respectively (Fig. F7).

\section{Unit 2}

Intervals: Sections 307-U1316A-5H-6, $115 \mathrm{~cm}$, through 7H-1, $26 \mathrm{~cm}$; 307-U1316B-6H-2, 70 $\mathrm{cm}$, through 7H-5, $46 \mathrm{~cm}$; and 307-U1316C$1 \mathrm{R}-1,0 \mathrm{~cm}$, through $2 \mathrm{R}-2,70 \mathrm{~cm}$

Depths: Hole U1316A: 44.40-55.06 mbsf, Hole U1316B: 45.20-58.30 mbsf, and Hole U1316C: 40.00-51.50 mbsf

Age: 0.46-1.95 Ma; upper Pliocene-Pleistocene (from last-appearance datum [LAD] of Discoaster triadiatus to LAD of Pseudomiliania lacunosa)

Unit 2 is very heterogeneous and consists of coralbearing layers interbedded with sands, silty sands, silt, and silty clays (Fig. F4). It is divided in two subunits by a distinct erosional unconformity. Subunit $2 \mathrm{~A}$ is dominated by siliciclastic fine to medium sands, whereas corals predominate in Subunit 2B (Figs. F8, F9).

\section{Subunit 2A}

Intervals: Sections 307-U1316A-5H-6, $117 \mathrm{~cm}$, through $6 \mathrm{H}-4,105 \mathrm{~cm}$; and 307-U1316B-6H$2,70 \mathrm{~cm}$, to $7 \mathrm{H}-1,45 \mathrm{~cm}$

Depths: Hole U1316A: 44.40-50.90 mbsf and Hole U1316B: 45.20-53.40 mbsf

Age: $0.46-1.95 \mathrm{Ma}$ (from LAD of $D$. triadiatus to LAD of $P$. lacunosa)

Subunit $2 \mathrm{~A}$ is dominated by fine to medium sand and rarely coarse sands that grade upward into silty clay interbedded with fine-sand and silt layers. In Hole U1316A, Subunit 2A is further divided into six, or possibly seven, fining-upward sequences with erosional contacts at their bases (at depths of 44.90, 45.20 , 46.00, 46.90, 48.10, 49.20, and $50.90 \mathrm{mbsf}$ ). These fining-upward sequences can be correlated to measured cyclic changes in the natural gamma ray $\log$ (Fig. F9). Dropstones are common within these intervals and range up to $3 \mathrm{~cm}$ in diameter.

\section{Subunit 2B}

Intervals: Sections 307-U1316A-6H-4, $1.05 \mathrm{~cm}$, through 7H-1, $26 \mathrm{~cm}$; 307-U1316B-7H-1, 45 $\mathrm{cm}$, through $7 \mathrm{H}-5,46 \mathrm{~cm}$; and 307-U1316C2R-1, $12 \mathrm{~cm}$, through 2R-2, $70 \mathrm{~cm}$

Depths: Hole U1316A: 50.90-55.06 mbsf, Hole U1316B: 53.45-58.30 mbsf, and Hole U1316C: 49.32-51.50 mbsf

Age: $0.46-1.95 \mathrm{Ma}$ (from LAD of D. triadiatus to LAD of $P$. lacunosa) 
Corals occur in distinct layers interbedded with siliciclastic sediments in Subunit 2B. Thicknesses of the coral-bearing layers vary from 20 to $170 \mathrm{~cm}$. The coral assemblage in these intervals is dominated by L. pertusa. Preservation of the corals is normally poor, but in some cases the primary aragonitic mineralogy of the corals is still preserved. The coral layers commonly display a floatstone to rudstone texture. Other coral species, such as Madrepora oculata, Desmophyllum crsitagalli, Dendrophyllia cornigera, and caryophyllid coral, are often associated with $L$. pertusa in present-day environments; however, they are not likely observed because of poor preservation.

In the upper parts of the subunit, from 50.90 to 51.40 mbsf in Hole U1316A, a dense rudstone rich in highly fragmented corals occurs. The top of the rudstone defines the boundary between Subunit $2 \mathrm{~A}$ and 2B. A likely corresponding layer in Hole U1316B was identified at 53.40-53.60 mbsf (Section 307-U1316B$7 \mathrm{H}-1$ ); however, the very coarse reworked layer could also represent fallen drilling breccia commonly found at the top of Section 1 in some cores.

\section{Unit 3}

Intervals: Sections 307-U1316A-7H-1, $26 \mathrm{~cm}$, through $21 \mathrm{H}-\mathrm{CC}, 37 \mathrm{~cm}$; 307-U1316B-7H-5, $46 \mathrm{~cm}$, through $8 \mathrm{H}-\mathrm{CC}, 18 \mathrm{~cm}$; and $307-$ U1316C-2R-2, $70 \mathrm{~cm}$, through 11R-CC, 13 $\mathrm{cm}$

Depths: Hole U1316A: 55.06-132.60 mbsf, Hole U1316B: 58.30-59.50 mbsf, and Hole U1316C: $51.50-143.10 \mathrm{mbsf}$

Age: 15.6-18.3 Ma; early-middle Miocene (before LAD of Helicosphaera ampliaperta and after FAD of Sphenolithus heteromorphus)

Unit 3 is divided into two subunits mostly based on the carbonate content of the sediments rather than on visual differences (Fig. F25). The upper section, Subunit 3A, generally consists of greenish gray sandy silt and clay with carbonate content at $\sim 30 \mathrm{wt} \%$, whereas the lower section of the core, Subunit 3B, consists of similar color and grain-size material but with carbonate content $>50 \mathrm{wt} \%$. The top of Unit 3 consists of lower-middle Miocene sediments. The overlying sediments of Unit 2 are late Pliocene-early Pleistocene age; therefore, this boundary represents a major hiatus.

\section{Subunit 3A}

Intervals: Sections 307-U1316A-7H-1, $26 \mathrm{~cm}$, through 20X-CC, $43 \mathrm{~cm}$; and 307-U1316B$7 \mathrm{H}-5,46 \mathrm{~cm}$, through $8 \mathrm{H}-\mathrm{CC}, 18 \mathrm{~cm}$

Depths: Hole U1316A: 55.06-121.3 mbsf and Hole U1316B: 58.30-59.50 mbsf
Age: 15.6-18.3 Ma; early-middle Miocene (before LAD of $H$. ampliaperta and after FAD of $S$. heteromorphus)

The boundary contact with overlying Unit 2 is erosive. The uppermost $10 \mathrm{~cm}$ shows gradual change from light gray to greenish gray (Fig. F10). The erosional surface shows no evidence of submarine lithification or $\mathrm{Fe} / \mathrm{Mn}$ impregnation. The sediments of Subunit 3A are mostly composed of greenish gray, well sorted, poorly to moderately lithified clayey and sandy silts that are frequently mottled (Fig. F4). The greenish gray color is likely due to the presence of glauconite. At several intervals, thin centimeterthick layers of fine bioclastic sand with echinoid spines, bivalves, and gastropods are found. Otherwise, the subunit is characterized by generally homogeneous sediments. These sandy layers are recorded as distinct decreases in natural gamma radiation (NGR) (Fig. F30). Aragonitic mollusks are partly preserved or seen as molds. Sporadic lithoclasts, shell fragments, and other bioclasts are found disseminated throughout the subunit. Apart from quartz, nannofossils are the primary sediment component. X-ray diffraction data indicate that dolomite occurs in low concentrations throughout the subunit but is $>20 \%$ in distinct layers (e.g., in Hole U1316A at 90 and $120 \mathrm{mbsf})$.

Core disturbance of Subunit 3A below $66.30 \mathrm{mbsf}$ is high because of a change from APC to XCB coring. This is expressed in the formation of sediment "biscuits," where coherent and in situ sediment biscuits are separated by a mixture of ground-up sediment and drilling mud (Fig. F11).

\section{Subunit 3B}

Interval: Sections 307-U1316A-20X-CC, $43 \mathrm{~cm}$, through 21X-CC, $33 \mathrm{~cm}$

Depth: Hole U1316A: 121.3-132.5 mbsf

Age: 15.6-18.3 Ma; early-middle Miocene (before LAD of $H$. ampliaperta and after FAD of $S$. heteromorphus)

Subunit 3B appears similar in color, texture, and grain size to the overlying Subunit $3 \mathrm{~A}$ but has a significantly higher carbonate content (>50 wt $\%$ ), thus placing it within the carbonate sediment classification regime outlined in "Lithostratigraphy" in the "Methods" chapter. The sediments consist of moderately lithified, bioturbated, and mottled clayey to sandy silt with infrequently dispersed shells and shell fragments (Fig. F4). The sediment matrix composition is comparable to Subunit 3A but contains more nannofossils. Coring disturbance in Subunit 3B is high. Frequent distinct layers of highly lithified sediment occur throughout the subunit. 


\section{Discussion}

Sediments recovered from Site U1316, located basinward of Challenger Mound, contain a sedimentary suite of pre-, syn-, and postmound growth phases. A central objective is to correlate Site U1316 with the on-mound Site U1317 in order to understand the sedimentary processes related to mound growth and burial history.

The top of Unit 3 is believed to represent the major unconformity observed in many seismic sections of Porcupine Seabight (e.g., Van Rooij et al., 2003) on which the cold-water coral mounds began to grow in this region. This distinct boundary represents a major hiatus between early-middle Miocene and late Pliocene or early Pleistocene (see "Biostratigraphy"). Immediately above this boundary, the base of Unit 2 is characterized by a coral layer. Because of the poor preservation and complex texture of the coral rudstone, it has not been possible to distinguish whether the corals were autochthonous or allochthonous. This would be an important distinction as in situ buried corals would imply a wide initial mud-layer mound base in contrast to corals transported from the adjacent Challenger Mound. For the uppermost coral horizon in Hole U1316A (50.90-51.60 mbsf), a debris flow transport process is suggested by (1) the high fragmentation of corals compared to the coral-bearing horizons below and (2) the fine mudstone matrix sediment between the corals. The abrupt change in sediment composition from a coral-dominated to a siliciclastic-dominated sediment between Subunits 2B and 2A forms the basis for implying major change in oceanographic conditions and subsequent mound growth. However, this hypothesis must be tested in forthcoming analyses, in particular with an improved age model and paleoclimatic reconstruction of Sites U1316 and U1317.

The general decrease in grain sizes in Unit 1, compared to those in Unit 2, possibly reflect a decrease in energy of the bottom current regime. The welldeveloped laminations in Subunit 1B mostly exibit thin fine-sand layers grading upward into silty clay. These layers are interpreted as turbidites. Restriction of dropstones to specific intervals in Unit 1 may indicate deglaciation events.

\section{Biostratigraphy}

Core catcher samples from each core of Holes U1316A, U1316B, and U1316C were examined for nannofossils, and Hole U1316A was examined for planktonic foraminifers in order to provide a shipboard biostratigraphic framework for recovered sediment. In several intervals, additional high-resolution sampling was performed in order to better constrain ages in stratigraphically important horizons. Nannofossils are moderately to well preserved in all sediments, except for Samples 307-U1316A-10H-CC (79.8 mbsf) and 15-CC (95.5 mbsf), which are barren of nannofossils. The preservation of planktonic foraminifers in Hole U1316A ranges from good to moderate. Samples from Section 307-U1316A-15X-CC (95.5 mbsf) contain low abundances of planktonic foraminifers, but in other samples the abundances are moderate to abundant.

\section{Calcareous nannofossils}

The middle-upper Pleistocene E. huxleyi Zone is represented by material recovered in Samples 307U1316A-1H-CC (6.8 mbsf) through 4H-CC (35.9 mbsf) (Figs. F12, F13). These sections contain abundant reworked Late Cretaceous nannofossils. The middle Pleistocene Pseudomiliania lacunosa Zone $(0.46-0.96 \mathrm{Ma})$ is found only in Sample 307U1316A-5H-CC (44.8 mbsf) (Fig. F13). The upper Pliocene to lower Pleistocene Calcidiscus macintyrei Zone (1.59-1.95 Ma) was recovered only in Sample 307-U1316A-6H-CC (54.9 mbsf) (Fig. F13). There is a likely hiatus between Samples 307-U1316A-5H-CC (lithostratigraphic Subunit 2A) and 6H-CC (Subunit 2B).

The lower-middle Miocene Zone CN3 is represented in Sample 307-U1316A-7H-CC (57.8 mbsf) (Fig. F13). There is a significant hiatus of $\sim 12$ m.y. between Samples 307-U1316A-6H-CC (Unit 2) and 7H-CC (Unit 3). Results of high-resolution sampling specify this hiatus between Samples 307-U1316A-7H-1, 25 $\mathrm{cm}(55.05 \mathrm{mbsf})$, and $7 \mathrm{H}-127 \mathrm{~cm}$ (55.07 mbsf), at the boundary of two lithostratigraphic units (see "Lithostratigraphy").

The common occurrences of several age-diagnostic nannofossils identify the interval from Sample 307U1316A-7H-CC (57.8 mbsf) through 21H-CC (132.2 mbsf) as lower-middle Miocene (Unit 3). These diagnostic taxa include Sphenolithus heteromorphus, Helicosphaera ampliaperta, Discoaster deflandrei, Reticulofenestra gartnerii, and Cyclicargolithus floridanus (Fig. F13; Table T2). The preservation of nannofossils is generally poor to moderate in the upper part of the unit (from Section 307-U1316A-7H-CC [57.8 mbsf] through 15X-CC [95.5 mbsf]) but is good in the lower part of the unit (from Section 307-U1316A16X-CC [108.5 mbsf] through 21X-CC [132.2 mbsf]). Reworking is not common.

Hole U1316C was used to fill in stratigraphic gaps, as it spans from 49.2 to $142.0 \mathrm{mbsf}$ and was further useful for examining the hiatus at 55.06 mbsf in Hole U1316A. In addition to samples from core catchers, nannofossil biostratigraphy was derived from sam- 
ples located within the actual core (Table T3). Nannofossil biostratigraphy indicates that lower-middle Miocene sediment spans the lower part of Hole U1316C (49.2-143.2 mbsf) (Table T3).

\section{Planktonic foraminifers}

The planktonic foraminifer biostratigraphy identified two different ages in Hole U1316A. These are Zones SN14 and M5 6 (Jenkins, 1985, 1993), which correspond to the Pleistocene and early-middle Miocene, respectively (Fig. F12; Table T4). Globorotalia truncatulinoides (Fig. F14) was found in Sample 307U1316-6H-CC (54.9 mbsf) but was not observed in any other samples. The FAD of $G$. truncatulinoides defining the base of Zone SN14 was tentatively placed just above this horizon. Globorotalia inflata also has its first appearance in Sample 307-U1316-6H-CC (54.9 mbsf). This appearance indicates ages younger than late Pliocene (Zone SN13). Age of the sediment below Sample 307-U1316-7H-CC is assigned to the early-middle Miocene by the occurrence of Praeobulina sicanus (Figs. F14, F15).

The Pleistocene planktonic foraminifer assemblage from Hole U1316A is dominated by cool- to temperate-water taxa Globigerina bulloides, Neogloboquadrina incompta, and Neogloboquadrina pachyderma (dextral and sinistral) (Figs. F14, F15). It is noteworthy that typical cold-water species $N$. pachyderma commonly occurs in Unit 1 (Fig. F16). Warmer water taxa, Globorotalia crassaformis, Globorotalia crassula, G. inflata, Globorotalia scitula, G. truncatulinoides, Orbulina universa, and Globigerinoides sp. are less frequent.

\section{Benthic foraminifers}

Sediments from Hole U1316A yield diverse assemblages of benthic foraminifers (Fig. F17). Shallow-water species, such as Elphidium excavatum and Islandiella norcrossi are common in lithostratigraphic Unit 1 but rare in Units 2 and 3. Otherwise, there is no significant difference in assemblages among the three lithostratigraphic units. Species associated with cold seepage, Bulimmina marginata and Bulimmina sp. A, are common throughout Hole U1316A (Fig. F18).

\section{Discussion}

An overview of the nannofossil biostratigraphy in Holes U1316A, U1316B, and U1316C indicates the uppermost $44 \mathrm{~m}$ of sediment is middle-upper Pleistocene $(<0.26 \mathrm{Ma})$ and contains an abundant amount of reworked Late Cretaceous nannofossils. Below this section lies a thin package of uppermost Pliocene to middle Pleistocene sediment. At the boundary between lithostratigraphic Units 2 and 3
(55.05 mbsf), a hiatus was recognized ranging from early-middle Miocene to latest Pliocene. The lower middle Miocene sediment continues to the base of Holes U1316A, U1316B, and U1316C (Fig. F12).

Planktonic foraminifer biostratigraphy indicates that sediments recovered from Hole U1316A range in age from Quaternary to early-middle Miocene (Fig. F12). The planktonic foraminifers indicate a hiatus at $55.05 \mathrm{mbsf}$, consisting of planktonic foraminifer Zones M4 to SN13 of Jenkins $(1983,1995)$. There is no inconsistency with calcareous nannofossil biostratigraphy (Fig. F12).

\section{Paleomagnetism}

Shipboard paleomagnetic measurements were conducted on cores from Holes U1316A, U1316B, and U1316C. Alternating-field (AF) demagnetization of the natural remanent magnetization (NRM) was conducted up to $20 \mathrm{mT}$ in $5 \mathrm{mT}$ steps on Section 307U1316A-1H-1. Based on this demagnetization experiment (Fig. F19), the other sections from Site U1316 were demagnetized at 15 and $20 \mathrm{mT}$. For Holes U1316A and U1316C, NRM and magnetizations after two-step demagnetization were measured on archive halves, whereas for Hole U1316B, whole-round sections were measured. Discrete samples were taken from the working halves of Hole U1316A for subsequent shore-based magnetostratigraphic and rock magnetic studies.

Inclination data are clustered around $\sim 66^{\circ}$ in the uppermost part and become more scattered at $\sim 48 \mathrm{mbsf}$ in Hole U1316A and $~ 50.5$ mbsf in Hole U1316B (Fig. F20). The upper values are approaching $\sim 68^{\circ}$, which is the expected inclination at the site latitude $\left(51.4^{\circ} \mathrm{N}\right)$. Below $55.95 \mathrm{mbsf}$ in Hole U1316A and 58.7 mbsf in Hole U1316B, the inclinations decline to lower values. Below $76 \mathrm{mbsf}$, the inclination data cluster again around $\sim 66^{\circ}$. The inclination data between 120 and 136 mbsf in Hole U1316C could indicate a reversal event; however, inclination data have to be considered with care because the scattering of the data below 65 mbsf in Holes U1316A and U1316C can be influenced by possible core disturbance during XCB drilling (i.e., "biscuit-structure"). On the other hand, the presence of carbonate-rich materials, characterized by weak magnetic intensities, would explain the altered data in the lower parts.

Declination data could only be corrected for in Cores $307-\mathrm{U} 1316 \mathrm{~A}-3 \mathrm{H}$ to $7 \mathrm{H}$ and $307-\mathrm{U} 1316 \mathrm{~B}-3 \mathrm{H}$ to $7 \mathrm{H}$. Like the inclination data, the declination data are more scattered at 48-55.95 mbsf in Hole U1316A 
and 50.5-58.7 mbsf in Hole U1316B. The reliability of the inclination and declination data had to be interpreted carefully because bias and background noise (due to the motion of the ship) in the cryogenic magnetometer and a magnetic overprint gathered during drilling influenced the measurements. This was especially critical for the low magnetic intensities measured in the carbonate-rich sediments. These obstacles manifest in the form of an artificial magnetic overprint pointing downward in the core.

The magnetic intensities in Holes U1316A and U1316B reached values between $15 \mathrm{~mA} / \mathrm{m}$ (NRM) and $45 \mathrm{~mA} / \mathrm{m}$ (20 mT intensity) in the uppermost part of the holes and slightly increased to depths of 44 mbsf in Hole U1316A and 45.45 mbsf in Hole U1316B (Fig. F21). Below these depths, intensities decreased again in different steps. Between 44 and 48 mbsf in Hole U1316A and 45.45 and 50.5 mbsf in Hole U1316B, values are again in the same range as the uppermost sections. Low values of $1-3 \mathrm{~mA} / \mathrm{m}(20$ $\mathrm{mT}$ intensity) are reached between 48 and 55.95 mbsf in Hole U1316A and 50.5 and 58.7 mbsf in Hole U1316B and fall in the lowermost sections within the range of the noise level $(0.1-0.01 \mathrm{~mA} / \mathrm{m}$ at $20 \mathrm{mT}$ intensity). The intensities follow the same trend as the magnetic susceptibilities. This suggests that the concentration of magnetic minerals, magnetic mineralogy, and size of the magnetic minerals have a strong impact on the intensities. The impact of the geomagnetic intensity is secondary. The low intensity record and the low susceptibilities below 55.95 mbsf in Hole U1316A, 58.7 mbsf in Hole U1316B, and 52 mbsf in Hole U1316C are typical for carbonate-rich sediments.

The effect of the magnetic mineral concentration and composition on the intensity could be normalized by dividing the intensities by the magnetic susceptibilities for paleomagnetic measurements made on whole-round cores (Hole U1316B). Both were measured on the same whole-round sections with exactly the same volume, which makes susceptibility an excellent parameter for the normalization of the intensities (Fig. F21). Measurements on whole-round sections did not affect the results.

As a result of uncertainty in polarity, the presence of a large hiatus in the sedimentary record, and limitations in the reliability of the directional data from the shipboard cryogenic magnetometer, correlation to the geomagnetic polarity timescale was severely limited. The predominantly normal polarities above 55.95 and 58.7 mbsf are correlated with the Brunhes Chron, with an age $<0.78 \mathrm{Ma}$.

\section{Geochemistry and microbiology}

Geochemistry

A total of 38 interstitial water samples were taken from Holes U1316A, U1316B, and U1316C (19, 12, and 7 samples, respectively). One interstitial water sample per core was collected from Hole U1316A. Two samples per core were collected from Hole U1316B. In Hole U1316C, one interstitial water sample per core was collected from Cores 307-U1316C$4 \mathrm{R}$ through 9R and also 11R.

\section{Interstitial water and gas}

Variations in interstitial water composition at this site are driven principally by microbially mediated reactions, diffusion of chemical species resulting from diagenesis at depths greater than those sampled, and sediment accumulation and burial (Table T5).

Strontium, lithium, and boron have similar profiles (Fig. F22A-F22C). The concentrations of all three are relatively constant between the seafloor and 20 mbsf. Concentrations then smoothly increase in a concave-upward fashion to a maximum at $120 \mathrm{mbsf}$. These three elements covary linearly between the seafloor and $105 \mathrm{mbsf}$, implying that in this interval all three behave nearly conservatively (Fig. F23). Although the decrease in the slope of the profiles with depth may in part reflect decreasing diffusivity with depth, we attribute the shape of the profiles to the high sedimentation rates that characterize Unit 1 sediments at this site. Higher concentrations of these elements at depth are most likely the result of carbonate diagenesis for $\mathrm{Sr}$ and silicate diagenesis for $\mathrm{Li}$ and $\mathrm{B}$.

In contrast, the concentration profiles of alkalinity, dissolved inorganic carbon (DIC), sulfate, Fe, Mn, ammonium, dissolved methane, and dissolved ethane are affected by microbial activity (Fig. F22DF22L). Alkalinity and DIC have similar downhole profiles. Both are slightly elevated relative to seawater in the uppermost core at $1.4 \mathrm{mbsf}$ and rise to a local maximum at $\sim 4.5 \mathrm{mbsf}$. There is a local minimum at $\sim 20$ mbsf followed by a broad maximum centered near 100 mbsf. The maximum at $100 \mathrm{mbsf}$ is most likely due to anaerobic methane oxidation. Below this depth, values of both DIC and alkalinity decrease toward the bottom of the hole.

Dissolved methane concentrations (based on analyses of the safety gas samples) (see "Geochemistry and microbiology" in the "Methods" chapter) are below detection $(\sim 0.2 \mu \mathrm{M})$ to a depth of 49.8 mbsf (Fig. F22J; Table T6). There is a small maximum centered near $80 \mathrm{mbsf}$ and concentrations increase 
below 100 mbsf, with concentrations reaching $2 \mu \mathrm{M}$ by 129.8 mbsf. The gradient between $100 \mathrm{mbsf}$ and the bottom of the hole is due to production (methanogenesis) and diffusion from within the deeper Miocene sediments and anaerobic methane oxidation centered at $\sim 100$ mbsf. Adsorbed methane (based on the difference of samples treated with $\mathrm{NaOH}$ and the safety gas samples) is above the detection limit throughout the hole and generally increases with depth (Fig. F22K).

Dissolved ethane remains below the detection limit until 79 mbsf (Fig. F22L). Like methane, it generally increases at greater depths and the gradient implies anaerobic consumption. At the methane-sulfate transition ( $80 \mathrm{mbsf})$, the ethane/methane ratio is higher than at greater depths, which suggests that methane is preferentially consumed through anaerobic microbial processes.

The seawater concentration of dissolved sulfate is $28.9 \mathrm{mM}$, and at $1.4 \mathrm{mbsf}$ it is already depleted to $25.2 \mathrm{mM}$ (Fig. F22F). Sulfate reaches a local minimum of $18.3 \mathrm{mM}$ between $\sim 10$ and $20 \mathrm{mbsf}$, indicative of sulfate reduction in the $0-10 \mathrm{mbsf}$ interval. It then decreases nearly linearly until 110 mbsf. Between 110 and 137.8 mbsf, measured concentrations are between 5 and $7 \mathrm{mM}$. Minimum sulfate concentrations of 4-6 $\mathrm{mM}$ are reached at depths below 95 mbsf and overlap the methane-bearing interstitial waters.

Similar to sulfate, dissolved ammonium reaches a local maximum between 10 and 20 mbsf, consistent with sulfate reduction and the oxidation of nitrogencontaining organic matter (Fig. F22I). Between 40 mbsf and the bottom of the hole, the slight concavedownward profile implies additional metabolism of nitrogen-containing organic matter.

Dissolved Mn has a maximum at the shallowest depth sampled and drops sharply at $6.9 \mathrm{mbsf}$ (Fig. F22H). From there its concentration decreases until 60 mbsf, where it remains constant at the analytical detection limit. Dissolved Fe is scattered but has higher values in the upper section of the core from 0 to $\sim 50$ mbsf (Fig. F22H).

Concentrations of $\mathrm{Ca}^{2+}$ are similar to that of seawater at the top of the pore water profile and increase slightly downcore to a value of $12.2 \mathrm{mM}$ (Fig. F24). This gradual trend is overprinted by short-lived excursions to slightly higher values at $\sim 30,45$, and 120 mbsf. Magnesium concentrations show a gradual decrease downcore, from $\sim 51 \mathrm{mM}$ at the top of the profile to $\sim 35 \mathrm{mM}$ in the deepest sample. At $\sim 30 \mathrm{mbsf}$, values increase to $51 \mathrm{mM}$. This excursion matches the excursion evident at the same depth in the calcium pore water profile.

\section{Sediments}

Carbonate is present at significant levels throughout Hole U1316A. In the upper $50 \mathrm{mbsf}$, it scatters around an average of $17 \mathrm{wt} \%$ (Fig. F25; Table T7). It then increases to $60 \mathrm{wt} \%$ over a short interval between $\sim 50$ and 55 mbsf. Between $\sim 65$ and 119 mbsf, it is again relatively constant with an average of 28 $\mathrm{wt} \%$. At greater depths there is a monotonic increase to $64 \mathrm{wt} \%$.

\section{Microbiology}

\section{Whole-round core and catwalk sampling}

Syringe samples were taken from Hole U1316A (Fig. F26), and whole-round cores (WRCs) plus additional syringe samples were taken from Holes U1316B and U1316C for shore-based work. For Hole U1316B, a 2 $\mathrm{m}$ section from each core was selected on the catwalk. After removal of the interstitial water sample together with a variety of smaller syringe samples, the remainder was taken directly from the catwalk to cold storage at $10^{\circ} \mathrm{C}$, where WRC sections were cut and properly packed. For Hole U1316C, one or two $1.5 \mathrm{~m}$ sections from each core were selected and run through the multisensor core logger (MSCL). After the interstitial water and headspace gas samples were taken from the core-end, the remainder of the core was taken to cold storage, where the core section was cut and packed (see "Geochemistry and microbiology" in the "Methods" chapter). Appropriately packed samples were stored at either $+4^{\circ} \mathrm{C}$ or $-80^{\circ} \mathrm{C}$. The distribution and packing/storing requirements of all samples and their sample codes are given in Figures F27 and F28. A total of 287 WRC/syringe samples were obtained.

\section{Total prokaryote enumeration}

Samples of $1 \mathrm{~cm}^{3}$ plugs for total prokaryote enumeration were taken during core processing on the catwalk from Holes U1316A (19 samples between the near surface and $129.70 \mathrm{mbsf}$ ) and U1316C (7 samples between 74.20 and $137.80 \mathrm{mbsf}$ ). All the samples in Hole U1316C were stored for later, shorebased processing.

Prokaryotes were present in all samples studied to the depth of 129.70 mbsf (Fig. F29). The detection limit was estimated at $2 \times 10^{5}$ cells $/ \mathrm{cm}^{3}$, based on calculations on a single membrane filter. For each sample, duplicate filters were used to provide a measure of variability. Where a zero count occurred, the prokaryote population was estimated by combining the data from both membranes and treating it as one subsample. This provides the only possible estimate of the population size in such samples but does not allow any measure of variability. 
The overall depth profile of cell numbers per cubic centimeter initially follows a trend observed at other Ocean Drilling Program sites (Parkes et al., 2000), although there are some substantial deviations (Fig. F29). At approximately the base of lithostratigraphic Unit 1 (40.15 mbsf) (see "Lithostratigraphy") cell numbers decrease rapidly from the largest population observed in this hole, $3.58 \times 10^{7}$ cells $/ \mathrm{cm}^{3}$ (Sample $307-\mathrm{U} 1316 \mathrm{~A}-5 \mathrm{H}-3,135-140 \mathrm{~cm}$ ), to $3.18 \times 10^{5}$ cells $/ \mathrm{cm}^{3}$, the smallest population observed in this hole at 78.65 mbsf (Sample 10X-2, 135-140 cm). This is a 112-fold reduction in number over $38.5 \mathrm{~m}$ and approaches the detection limit. From 78.65 mbsf, cell numbers start to increase again and are back within prediction limits by 84.65 mbsf (Sample 307-U1316A-12X-1, 135-140 cm). For the remainder of this hole, they closely follow the predicted profile.

The major decrease starting between 40.19 mbsf (Sample 307-U1316A-5H-3, 135-140 cm) and 49.65 mbsf (Sample 6H-3, 135-140 cm) seems clearly linked to the lithologic change between Subunit 1B and Subunit 2B at 44.4 mbsf, where the sediment changes from laminated silty clays to silty clay and fine to medium sand (see "Lithostratigraphy"). However, the striking increase in prokaryote numbers from 78.65 mbsf (Sample 307-U1316A-10X-2, $135-140 \mathrm{~cm}$ ) seems to be related to pore water geochemical changes (Fig. F22) (see "Geochemistry"). At 78.8 mbsf there is the first significant appearance of methane and this continues to increase, albeit to low concentrations (maximum $=6000 \mathrm{ppm}$ at $118.69 \mathrm{mbsf}$ ), over the remainder of the hole. Methane represents a significant carbon source for some prokaryotes and is probably the reason for the increase in cell numbers. Interestingly, below 80 mbsf there is a small but persistent concavedownward departure from the linear decrease in the sulfate concentration profile that is observed between 20 and 80 mbsf. The changes in these two geochemical profiles suggest prokaryotic anaerobic oxidation of methane may be occurring below 80 mbsf.

Numbers of dividing cells (an index of growth activity) are typically between $5 \%$ and $10 \%$ of the total count. As expected, dividing cells, as a percentage of the total count, are high near the surface (Fig. F29). They then decrease rapidly to $\sim 5.3 \%$ at $11.65 \mathrm{mbsf}$ (Sample 307-U1316A-2H-3, 135-140 cm) before increasing again to $13.1 \%$ at 21.15 mbsf (Sample 3H-3, $135-140 \mathrm{~cm}$ ). Thereafter they decrease rapidly to $0 \%$ by 56.15 mbsf (Sample 307-U1316A-7H-1, 135-140 $\mathrm{cm}$ ), where they remain until 84.65 mbsf (Sample $12 \mathrm{X}-1,135-140 \mathrm{~cm}$ ). This nearly $30 \mathrm{~m}$ thick zone is characterized by a rapidly decreasing prokaryotic population and absence of any evidence of cell division and represents a dead zone in the sediment column. The reasons for this are not immediately apparent. Below $84.65 \mathrm{mbsf}$, significant numbers of cells in division were observed, rising from $0 \%$ at 84.65 mbsf to $\sim 22 \%$ at 94.35 mbsf (Sample 307U1316A-15X-1, 0-5 cm) and correlating with an increasing prokaryote population. These data need to be interpreted with caution as the absolute numbers of dividing and divided cells are very low and thus data variability is high. Nevertheless, the change from zero to high although variable levels of cell division is striking.

\section{Contamination tests}

\section{Perfluorocarbon tracer}

PFT was injected continuously into the drilling fluid during coring of Holes U1316B and U1316C $(1 \mathrm{~mL} / \mathrm{L}$ seawater drill fluid). Because PFT is dissolved in the drilling fluid rather than suspended as particles, these results are estimates of the potential for microbial contamination and provide an upper limit of actual microbial contamination. All air samples taken from the catwalk and the laboratory air tested negative for PFT, indicating that no background PFT signal was provided by the analytical procedures. All drill fluid samples investigated were positive for PFT, and some of the outer core scrapings were also positive (Table T8), whereas the maximum concentration of PFT in the outer core sections (Sample 307U1316C-9R-4, 125-130 cm) was about a factor of 5 times lower than in the drill fluid. In contrast to the outer core samples, PFT signal was not detected in any inner core samples (both APC and RCB) at Site U1316, indicating that seawater penetration into the core was minimal or absent.

\section{Particulate tracer}

Fluorescent microspheres were deployed in all cores from which microbiology (MBIO) samples were taken in Holes U1316B and U1316C. Subcores of 5 $\mathrm{cm}^{3}$ were taken from the bottom cut end of each MBIO section adjacent to the interstitial water WRC. Microspheres were detected in one sample from Hole U1316B and two samples from Hole U1316C (Table T8). Although it is not possible to accurately quantify the level of contamination, these numbers must be compared with the original microsphere suspension of 7,000,000 microspheres per microliter. The number of microspheres detected in Sample 307$\mathrm{U} 1316 \mathrm{~B}-6 \mathrm{H}-3,48.35-48.4 \mathrm{~cm}\left(42 / \mathrm{cm}^{3}\right)$ is still only equivalent to the estimated minimum of $6 \mathrm{pL} / \mathrm{cm}^{3}$, or $6 \mathrm{ppb}$. 


\section{Physical properties}

The physical properties measured on the cores from Site U1316 include magnetic susceptibility measured with the MSCL and with the multisensor track (MST), gamma ray attenuation (GRA) density, natural NGR, $P$-wave velocity measured continuously with the MST $P$-wave logger (PWL) and at discrete positions on the split cores with the $P$-wave velocity sensor (PWS), moisture and density (MAD), shear strength, and thermal conductivity. Good results were obtained with all types of equipment, except for the PWL measurements below $\sim 60$ mbsf. The acquisition of PWL data became unreliable with the use of XCB or RCB drilling because the gap between sediment and core liner blocks the acoustic signal. Shear strength measurements were only carried out on sediments from 0 to 50 mbsf in Hole U1316A; below 60 mbsf the sediment became too indurated to use the Torvane tool.

As recovery in the upper parts of the holes $(<\sim 60$ mbsf) was very good, nearly continuous records of the parameters were acquired. In the lower levels, however, recovery was less complete, and even after the integration of the data from the different holes, important data gaps persist (see also "Stratigraphic correlation"). The resulting spliced curves, expressed in meters composite depth (mcd) and constructed after splicing the data from the three holes at this site, are presented in Figure F30.

\section{Magnetic susceptibility}

Overall, the magnetic susceptibility measurements range from $5 \times 10^{-5}$ to $128 \times 10^{-5} \mathrm{SI}$ units. The overall trend of the magnetic susceptibility depth curve shows a very gradual increase in the upper $\sim 34 \mathrm{mcd}$ of the cores, although several sawtooth intervals of different strength and periodicity exist. A significant break in the overall trend is observed at $\sim 22 \mathrm{mcd}$ with a drop of $\sim 20 \times 10^{-5}$ SI units. From a depth of 36 mcd downhole, the magnetic susceptibility increases more rapidly and demonstrates more short-period variability with higher amplitudes. At 49 mcd, the magnetic susceptibility drops sharply to $\sim 30 \times 10^{-5}$ SI units, followed by a more gradual reduction to 60 mcd, reaching values as low as $3 \times 10^{-5}$ to $4 \times 10^{-5}$ SI units. Below this boundary, the magnetic susceptibility remains very low, largely varying between $3 \times$ $10^{-5}$ and $10 \times 10^{-5}$ SI units.

\section{Gamma ray attenuation, bulk density, and porosity}

Bulk density measurements (i.e., GRA-corrected density and MAD measurements) display parallel trends. GRA densities deduced from the MST are corrected in the unconsolidated section of the cores (upper 60 mcd of the core) according to the equation described in "Physical properties" in the "Methods" chapter. Density increases in the upper 6 mcd of the site from 1.8 to $2 \mathrm{~g} / \mathrm{cm}^{3}$. From there the values gradually decrease to $1.7 \mathrm{~g} / \mathrm{cm}^{3}$ and increase again to a clear maximum $\left(2.1 \mathrm{~g} / \mathrm{cm}^{3}\right)$ at a depth of $16 \mathrm{mcd}$. A second maximum is visible in the density data at $22 \mathrm{mcd}$ that coincides with the sharp drop in magnetic susceptibility. Below 22 mcd, density remains fairly constant until $30 \mathrm{mcd}$, after which the values show an increasing amount of scatter. This scatter in GRA data below 29 mcd occurs at a high frequency but gradually increases toward broader cycles and larger amplitudes with depth. Below $64 \mathrm{mcd}$, the average density stays very constant at $\sim 1.9 \mathrm{~g} / \mathrm{cm}^{3}$ with a slightly increasing trend downcore. GRA data shows more scatter than MAD data in the lower interval as a result of the core disturbance (biscuits) in the $\mathrm{XCB}$ cores in Hole U1316A.

\section{Natural gamma radiation}

The NGR depth curve at Site U1316 shows an overall gradual increase in the uppermost 16 mcd but is also characterized by high-frequency and high-amplitude variations, probably due to the short measurement time of five periods of $1 \mathrm{~s}$. After a slight decrease to $21 \mathrm{mcd}$, the overall trend stays constant at $\sim 50 \mathrm{cps}$ until a depth of $47 \mathrm{mcd}$, from where the NGR decreases to $30 \mathrm{cps}$ at $60 \mathrm{mcd}$. Below this depth, the average values stay lower than in the upper part and the high-frequency variations have lower amplitudes. Some large-scale cycles are present (e.g., 9096, 102-110, and 116-124 mcd); however, they are in many cases not completely surveyed because of gaps in the core recovery.

\section{Shear strength}

The shear strength, measured with the Torvane apparatus, shows three clear trends:

1. An increase from $\sim 0$ to $\sim 1.610^{3} \mathrm{~kg} / \mathrm{m}^{2}$ in the upper $7 \mathrm{mcd}$.

2. A nearly constant value between 7 and $27 \mathrm{mcd}$

3. A fairly steep increase to $3.510^{3} \mathrm{~kg} / \mathrm{m}^{2}$ at 50 mcd. At this point, the shear strength drops sharply to values comparable to those near the seafloor.

\section{P-wave velocity}

Although the acquisition of PWL data was sometimes problematic, especially in the deeper cores, there are still trends that can be derived from both the PWL and PWS data. Overall, the sonic velocity increases irregularly in the upper $7 \mathrm{mcd}$. Between 7 
and $17 \mathrm{mcd}$, both data sets show a pattern comparable to the GRA and bulk density measurements, culminating in a sharp maximum at $16 \mathrm{mcd}$. The secondary maximum at 22 mcd found in the GRA and bulk density values, however, is not visible in the $P$ wave data. From 16 mcd there is a very gradual increase in the sonic velocity, from 1550 to $1630 \mathrm{~m} / \mathrm{s}$ at $47 \mathrm{mcd}$. Between 47 and $60 \mathrm{mcd}$, the PWS data especially show considerable scatter and an overall increasing trend from 1600 to $1650 \mathrm{~m} / \mathrm{s}$. A jump in $P$ wave velocity is observed at $\sim 60 \mathrm{mcd}$. Below $60 \mathrm{mcd}$, data density is limited, but another gradually increasing trend can be seen, albeit with a lower gradient. The velocity in this interval is $\sim 1700 \mathrm{~m} / \mathrm{s}$, but sharp spikes occur at several distinct horizons. Finally, at a depth of $\sim 130 \mathrm{mcd}$, the sonic velocity increases sharply to $2000 \mathrm{~m} / \mathrm{s}$ and more. The PWS shows a deviation from the PWL data of $\sim 100 \mathrm{~m} / \mathrm{s}$, and there is a considerable offset between the PWS measurements of Hole U1316A and U1316C, which is probably caused by differences in coring techniques. The $\mathrm{XCB}$ cores have a lower velocity (by $\sim 200 \mathrm{~m} / \mathrm{s}$ ) than the RCB cores probably because of the ground-up sediment between and surrounding biscuits in the XCB cores.

\section{Thermal conductivity and in situ temperature measurements}

Deployment of the advanced piston corer temperature tool provided insight into the subsurface temperature distribution (Fig. F31). Two discrete temperature measurements in Hole U1316A were taken at 26.3 and 54.8 mbsf. The data show temperature gradients of $42^{\circ} \mathrm{C} / \mathrm{km}$.

\section{Interpretation}

Based on the overall physical property trends as described above, several physical property (PP) units can be defined, which correspond to major lithostratigraphic units (Fig. F30).

Unit PP1 comprises the subsurface and reaches to $\sim 6$ mcd. It is characterized by increasing shear strength, $P$-wave velocity, and density. Its lower boundary is marked by a negative peak in density, natural gamma radiation, and high $P$-wave velocities and by the end of the first sawtooth cycle in the magnetic susceptibility data. The interval illustrates the natural trends of bulk density, shear strength, magnetic susceptibility, and velocity as sediments become buried. The sharp drop in the different parameters that indicate its lower boundary, however, corresponds to a shell layer and an interval of silty material in lithostratigraphic Subunit 1A that otherwise is characterized by homogeneous muds. The upper part of the seismic profile displays high-frequency and highamplitude reflectors interpreted as drift deposits.

The definition of Unit PP2 is based on the characteristic pattern in the density and $P$-wave velocity, which shows a decrease followed by a sharp maximum at $17 \mathrm{mcd}$ and a secondary peak at $22 \mathrm{mcd}$. These intervals again correspond to siltier layers in Subunit 1A. The seismic expression of this unit is relatively low in amplitude compared to the surrounding seismic facies.

Unit PP3 (22-26 mcd) is defined by the absence of major features. Most parameters have a nearly constant value or a limited overall increase along a low gradient. It represents a homogeneous muddy sequence without major boundaries or changes in lithostratigraphic Subunit 1A.

The slightly concave natural gamma radiation profile in these upper three units (PP1-PP3) represents the high clay content. On seismic profiles this unit is characterized by a moderate amplitude and frequency and the reflector morphology is slightly wavy.

The clear change in trend of the shear strength at 26 mcd marks the onset of Unit PP4, which extends to $47 \mathrm{mcd}$. In the lower part of this unit, the magnetic susceptibility values increase strongly and the amplitudes of the cyclicity in the GRA density data become larger. This unit corresponds to lithostratigraphic Subunit 1B. The spikes in magnetic susceptibility coincide with sandy laminations in Subunit 1B. The $P$-wave velocity in this unit shows some peaks corresponding to coarser-grained layers. Unit PP4 corresponds in the seismic profile to a high-frequency and high-amplitude parallel reflectors. The frequency of the reflectors is higher than in the overlying facies.

Unit PP5 is marked by a sharp drop in magnetic susceptibility and shear strength and corresponds to sequences containing coral fragments. This drop in $P$ wave velocity can be correlated with low-amplitude seismic facies without internal reflectors on the seismic profiles of the site survey (Line P000660). The increase in carbonate content causes the decrease in magnetic susceptibility and also a gradual decrease in NGR because of the limited clay content in these intervals. The irregularity of the coral layers causes the scattering and partial reduction of the PWS values. The unit is sharply defined at $60 \mathrm{mcd}$ by a further reduction in magnetic susceptibility to values $<10 \times 10^{-5}$ SI units, a boundary identified as a major hiatus by biostratigraphy. The lower boundary is characterized by high $P$-wave velocity and a significant increase in density. These physical parameters of the sediments cause the high-amplitude reflector 
in the seismic profiles, which is interpreted as a significant erosional event of possible overconsolidated sediments.

Low magnetic susceptibility and fairly constant background levels of velocity and bulk density values are the main characteristics of Unit PP6. This unit corresponds to lithostratigraphic Unit 3, comprising Miocene nannofossil-rich sandy to clayey silts with a carbonate content between 30 and 50 wt $\%$. The low magnetic susceptibility values are caused partly by the high $\mathrm{CaCO}_{3}$ content of the material and by the limited amounts of magnetic minerals in the sediments. Cycles of natural gamma radiation counts have a negative correlation with the cyclicity of $P$-wave velocity. The increased carbonate content also results in a general reduction in NGR. Peak acoustic velocities have been measured up to $2500 \mathrm{~m} / \mathrm{s}$ and correspond with the high-amplitude seismic reflectors interpreted as the top of sigmoidal bodies in the lower drift deposit. The density of these layers is relatively high and the porosity low.

Unit PP7 is located below $130 \mathrm{mcd}$ and is characterized by the sharp increase in PWS values to $2000 \mathrm{~m} / \mathrm{s}$ and more. This increase in velocity is correlated to the high-amplitude reflector at the base of the sigmoidal bodies. Unfortunately, good PWL data were not obtained at this depth. Natural gamma radiation counts decrease, which suggests a lower clay content and increase in carbonate content. There is also no significant increase in density, which could be related to this velocity increase.

\section{Relationship between physical properties}

Statistical analysis and correlation tests have been performed on the different numerical data sets in order to evaluate the quality of the data, to make direct comparisons between different laboratory equipment, and to draw potential relationships among the physical property parameters. The statistical data analysis, including normality tests and confidence intervals for each individual core, assisted in the identification of outliers, which were quite numerous in the pycnometer results $(\sim 10 \%)$ and less frequent in the MST data ( $5 \%)$. These data have been filtered out before further processing. Figure F32 shows a matrix plot of the correlation between the physical parameters of the cores to aid in the identification of the most important physical parameters causing the seismic reflectors.

A clear change in the physical properties of the sediment can be seen at the boundary between Units PP5 and PP6 ( 60 mcd, Cores 7-8). Bulk sediment GRA density data and direct measurements (MAD bulk density) present a fairly good positive correla- tion from Units PP1 to PP5 (Cores 1-8) with both Pwave velocity measurements. Below $60 \mathrm{mcd}$, in Units PP6 and PP7 (Cores 8-21), sediment density remains rather stable; however, a slight but constant increase in the $P$-wave velocity (PWS) is present throughout both units. Natural gamma radiation shows a negative correlation with $P$-wave velocity for Units PP2-PP5 (Cores 2-7), and there is no linear relation for Units PP6 and PP7 (Cores 8-21). Shear strength in Units PP1-PP4 (unconsolidated sediments) (Cores 1-6) shows a good positive correlation with the $P$-wave velocity. A gradual increase in shear strength in Unit PP4 (Cores 4-6) is less visible in the $P$-wave logs.

Measurements taken for $P$-waves using PWL (MST) and PWS (sample) were compared in their mean, median, and distribution patterns to check for consistency in both data sets. It was noted that a constant shift from 50 to $100 \mathrm{~m} / \mathrm{s}$ was present from the PWS to the PWL. This might be due to different operations. From these correlations, it seems that the acoustic velocity is influenced by the density, clay content and in shear strength in unconsolidated sediments.

\section{Stratigraphic correlation}

Stratigraphic correlation at Site U1316 was carried out with the help of the Splicer software, as described in "Composite section development" in the "Methods" chapter. An mcd scale was constructed from the physical property data of Holes U1316A, U1316B, and U1316C (Tables T9, T10) as well as a spliced depth curve for most of the parameters (Fig. F30) at this site. The main physical properties used to construct the mcd scale were magnetic susceptibility from the MSCL, GRA density for the sequence above $\sim 60 \mathrm{mcd}$, and NGR for the interval below that. Information about biostratigraphy and lithologic contacts also aided in the construction of the mcd scale and spliced records. The correlation task was fairly straightforward for the upper sequence (correlation between Holes U1316A and U1316B), as many features appeared in the data that could be used as tie points (spikes, sawtooth trends, etc.). Below $\sim 60$ mcd, correlation between Holes U1316A and U1316C became more difficult because of limited recovery, the very low signal of some parameters (e.g., MSCL), and the use of different drilling techniques causing slight differences in the data. Overall, this results in a continuous spliced depth curve for most parameters above $60 \mathrm{mcd}$, whereas below this boundary some data gaps persist. The overall extension of the mcd scale versus the mbsf scale (as an approximation of the core expansion) is $9 \%$. 
An additional difficulty in the creation of continuous spliced depth curves was the sampling of long whole-round cores for microbiological analysis. Ideally, these microbiological sampling intervals should avoid overlap with the gaps between cores in the adjacent hole. In situations with fast core recovery, it is difficult to monitor this in real time, even when using data from the MSCL. Furthermore, the Splicer software is not adapted to allow the use of two separate portions of the same core in the spliced curve. Therefore, only either the interval above or below the microbiological sampling could be used for the spliced curves instead of both.

\section{Downhole measurements}

\section{Logging operations}

The triple combo and FMS-sonic tool strings (see Figure F8 in the "Methods" chapter) were planned for use in Hole U1316A. After completion of the APC and $\mathrm{XCB}$ drilling operation (bit size $=117 / 16$ inches) at 134 mbsf, the hole was displaced with $45 \mathrm{bbl}$ of 8.9 ppg sepiolite mud in preparation for logging. In order to get a maximum coverage of the short open hole interval, we decided to set up the pipe at 30 mbsf and break down the classic triple combo tool string into two shorter tool strings. The first included the Hostile Environment Gamma Ray Sonde, Accelerator Porosity Sonde, and Hostile Environment Litho-Density Sonde. The second included the digital Dual Induction Tool and the Dipole Sonic Imager from the standard FMS-sonic tool string. Unfortunately, an obstruction located $15 \mathrm{~m}$ below the pipe prevented logging. After extensive pumping and moving of the pipe without success, the operation in Hole U1316A was aborted (Table T11). Based on this experience, we took a more conservative approach (deeper pipe depth and heavier tool string) for the second attempt at logging Site U1316 in Hole U1316C. After completion of the RCB drilling operation (bit size $=97 / 8$ inches) at $143 \mathrm{mbsf}$, Hole U1316C was displaced with $44 \mathrm{bbl}$ of $8.9 \mathrm{ppg}$ sepiolite mud and the pipe set at 57 mbsf in preparation for logging. A summary of the logging operation at Hole U1316C is provided in Figure F33, and breakdowns of the chronology of the logging operations in Holes $\mathrm{U} 1316 \mathrm{~A}$ and $\mathrm{U} 1316 \mathrm{C}$ are provided in Tables T11 and T12, respectively. These tables include some details of the tools used. For Hole U1316C, tool rig-up was begun on 8 May 2005 at $0300 \mathrm{~h}$ and logging was completed by 8 May at $1330 \mathrm{~h}$. The triple combo tool string was run to the bottom of the hole (1097 mbrf, $143 \mathrm{mbsf}$ ) and logging began at $0635 \mathrm{~h}$ on May 8 . The caliper readings from the triple combo tool string suggested that the hole was in perfect condition for logging. The standard FMS-sonic tool string was rigged up and run to the bottom of the hole. Two passes were successfully acquired. The FMS-sonic tool string was retrieved to the rig floor, and logging operations were completed by $1330 \mathrm{~h}$ on 8 May. The heave conditions were excellent, typically $<1 \mathrm{~m}$ throughout the logging operation. Consequently, the wireline heave compensator experienced no problems during this operation.

\section{Data quality}

The triple combo tool string caliper indicated that hole conditions were very good in the entire open interval (57-143 mbsf) (Fig. F34A). Vertical acceleration of the FMS-sonic tool string, which integrates the effects of heave, sidewall contact, and wireline stretch on the tool string, indicated that hole conditions and stick-slip of the tool remained at moderate levels until the cable head entered the BHA (Fig. F34B). The orientation of the reference pad of the FMS (Fig. F34E, F34F) shows a very slow and progressive rotation. The two passes followed exactly the same path (Fig. F34G) in the bottom part of the hole (96-143 mbsf). In the upper part of the open hole, the two passes are complementary and improve the coverage of the borehole. The FMS images are of good quality. Electrical resistivity progressively increases downhole with highly resistive layers identified in the standard resistivity logs and the FMS images.

The original logs were depth-shifted to the seafloor. The seafloor depth was based on the step in gamma radiation in the triple combo logs (Fig. F35A). The seafloor depth differs by $1 \mathrm{~m}$ from the seafloor depth determined from the mudline. Using this reference scale, the pipe depth is placed at 57 mbsf. Gamma ray data from the triple combo tool string served as a reference by which the features in the equivalent logs of subsequent FMS-sonic runs were matched (Fig. F35B, F35C). The depth adjustments required to bring the match log in line with the base log have been applied to all other logs from the same tool string.

\section{Logging stratigraphy}

The logged section and logging units are characterized by the following:

1. The impulsive characters of resistivity (SFLU, IMPH, and IDPH) (Fig. F36C), porosity (APLC) (Fig. F36D), bulk density (RHOM) (Fig. F36D), and acoustic velocity $\left(V_{\mathrm{P}}\right)$ (Fig. F36F) logs in the upper, central, and lower part of the open hole.

2. Clear shifts in total spectral gamma radiation (HSGR) (Fig. F36A). 
3. Major changes in the cyclicity of thorium (HTHO) (Fig. F36B) and porosity (APLC) (Fig. F36D) logs.

Five logging units have been defined (Fig. F36G). All of these units correspond to lithostratigraphic Unit 3 (see "Lithostratigraphy").

\section{Logging Unit 1: Base of pipe (57-67 mbsf)}

Logging Unit 1 is characterized by a constant level of gamma radiation ( $\sim 35$ gAPI) and the impulsive nature of the electric resistivity logs. The base of this unit is characterized by a pronounced low in gamma radiation and porosity, and major peaks in resistivity and density. The mean acoustic velocity in logging Unit 1 is $\sim 1750 \mathrm{~m} / \mathrm{s}$.

\section{Logging Unit 2: 67-77 mbsf}

Logging Unit 2 is characterized by a progressive enrichment in gamma radiation mainly due to its Th (2-7 ppm) and K (0.7-1.2 wt\%) contributions. Porosity, density, $P$-wave velocity, and electrical resistivity are particularly constant over this interval. The base of this unit is characterized by the highest gamma radiation recorded in the open hole. Acoustic velocity in logging Unit 2 is $1950 \mathrm{~m} / \mathrm{s}$.

\section{Logging Unit 3: 77-99 mbsf}

Logging Unit 3, like logging Unit 1, is characterized by the impulsive characteristics of the electrical resistivity, porosity, and density logs. The increase of density associated both with an increase in the photoelectric factor and a decrease in gamma radiation suggests an enrichment in carbonate content. These thin layers are associated with a significant increase in acoustic velocity (up to $2400 \mathrm{~m} / \mathrm{s}$ ).

\section{Logging Unit 4: 99-118 mbsf}

Like logging Unit 2, this unit is characterized by low and constant electrical resistivity values. The density $\log$ is anticorrelated with both the porosity and gamma radiation logs, suggesting subtle variations in carbonate/clay content. The base of this unit is characterized by high porosity (low density) and a major drop in acoustic velocity.

\section{Logging Unit 5: 118-143 mbsf (bottom of the logged section)}

Depending on the location of the probe in the tool string, logging Unit 5 has been partly logged by these probes. Available records show high-frequency variations of resistivity and density similar to logging Units 1 and 3 . The difference between logging Units 1,3 , and 5 is the progressive increase in the magnitude of variations with depth. Electrical resistivity increases up to $5 \Omega \cdot \mathrm{m}$, and acoustic velocity is $>2700 \mathrm{~m} / \mathrm{s}$.

\section{Discussion}

Comparison between continuous and in situ logs with the whole-core MST records (natural gamma radiation, density, and velocity) and discrete sample MAD data provides the basis for depth-matching the core-derived mcd scale to a logging equivalent depth. This is a necessary step to correct for the expansion of the cores and obtain correct sedimentation and mass accumulation rate (see "Stratigraphic correlation"). The total gamma radiation counts, porosity, density, and velocity have the potential to be correlated to downhole logging data (Fig. F37).

Microresistivity (FMS; vertical resolution $=<1 \mathrm{~cm}$, sampling rate $=0.1$ inch $[2.5 \mathrm{~mm}]$ ) images can resolve the thickness and dip of the high-density layers (Fig. F38), which can be related to the sigmoidal reflectors identified in the seismic lines.

\section{References}

Beyer, A., Schenke, H.W., Klenke, M., and Niederjasper, F., 2003. High resolution bathymetry of the eastern slope of the Porcupine Seabight. Mar. Geol., 198:27-54. doi:10.1016/S0025-3227(03)00093-8

Foubert, A., Beck, T., Wheeler, A.J., Opderbecke, J., Grehan, A., Klages, M., Thiede, J., Henriet, J.-P., and the Polarstern ARK-XIX/3A Shipboard Party, 2005. New view of the Belgica mounds, Porcupine Seabight, NE Atlantic: preliminary results from the Polarstern ARKXIX/3a ROV cruise. In Freiwald, A., and Roberts, J.M. (Eds.), ColdWater Corals and Ecosystems: Heidelberg (Springer-Verlag), 403-415.

Foubert, A., Van Rooij, D., Blamart, D., and Henriet, J.-P., in press. X-ray imagery and physical core logging as a proxy of the content of cores in mound provinces; a case study from Porcupine Seabight, SW of Ireland. Int. J. Earth Sci.

Jenkins, D.G., 1985. Southern mid-latitude Paleocene to Holocene planktic foraminifera. In Bolli, H.M., Saunders, J.B., and Perch-Nielsen, K. (Eds.), Plankton Stratigraphy: Cambridge (Cambridge Univ. Press), 263-282.

Jenkins, D.G., 1993. Cenozoic southern mid- and high-latitude biostratigraphy and chronostratigraphy based on planktonic foraminifera. In Kennett, J.P., and Warnke, D.A. (Eds.), The Antarctic Paleoenvironment: A Perspective on Global Change. Antarct. Res. Ser., 60:125-144.

Parkes, R.J., Cragg, B.A., and Wellsbury, P., 2000. Recent studies on bacterial populations and processes in marine sediments: a review. Hydrogeol. Rev., 8:11-28.

Van Rooij, D., De Mol, B., Huvenne, V., Ivanov, M., and Henriet, J.-P., 2003. Seismic evidence of current-controlled sedimentation in the Belgica mound province, 
upper Porcupine slope, SW of Ireland. Mar. Geol., 195(14):31-53. doi:10.1016/S0025-3227(02)00681-3
Publication: 14 October 2006

MS 307-103 
Figure F1. Multibeam bathymetry (Beyer et al., 2003), showing location of Site U1316.

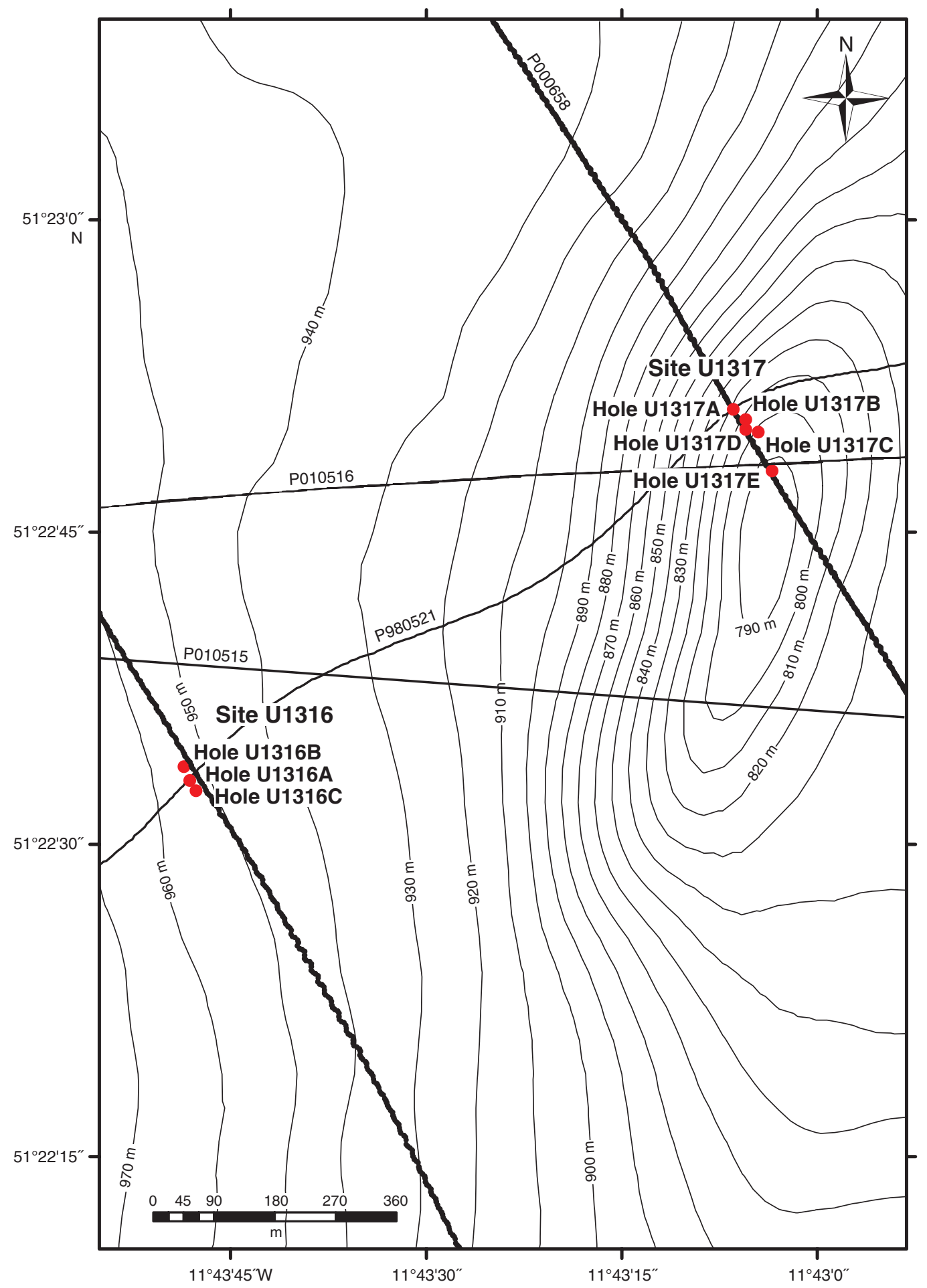


Figure F2. Downslope seismic profile at Site U1316 and adjacent Challenger Mound. Close-up shows the high-amplitude reflectors and lenticular structures underlying drift sediments and adjacent mound.

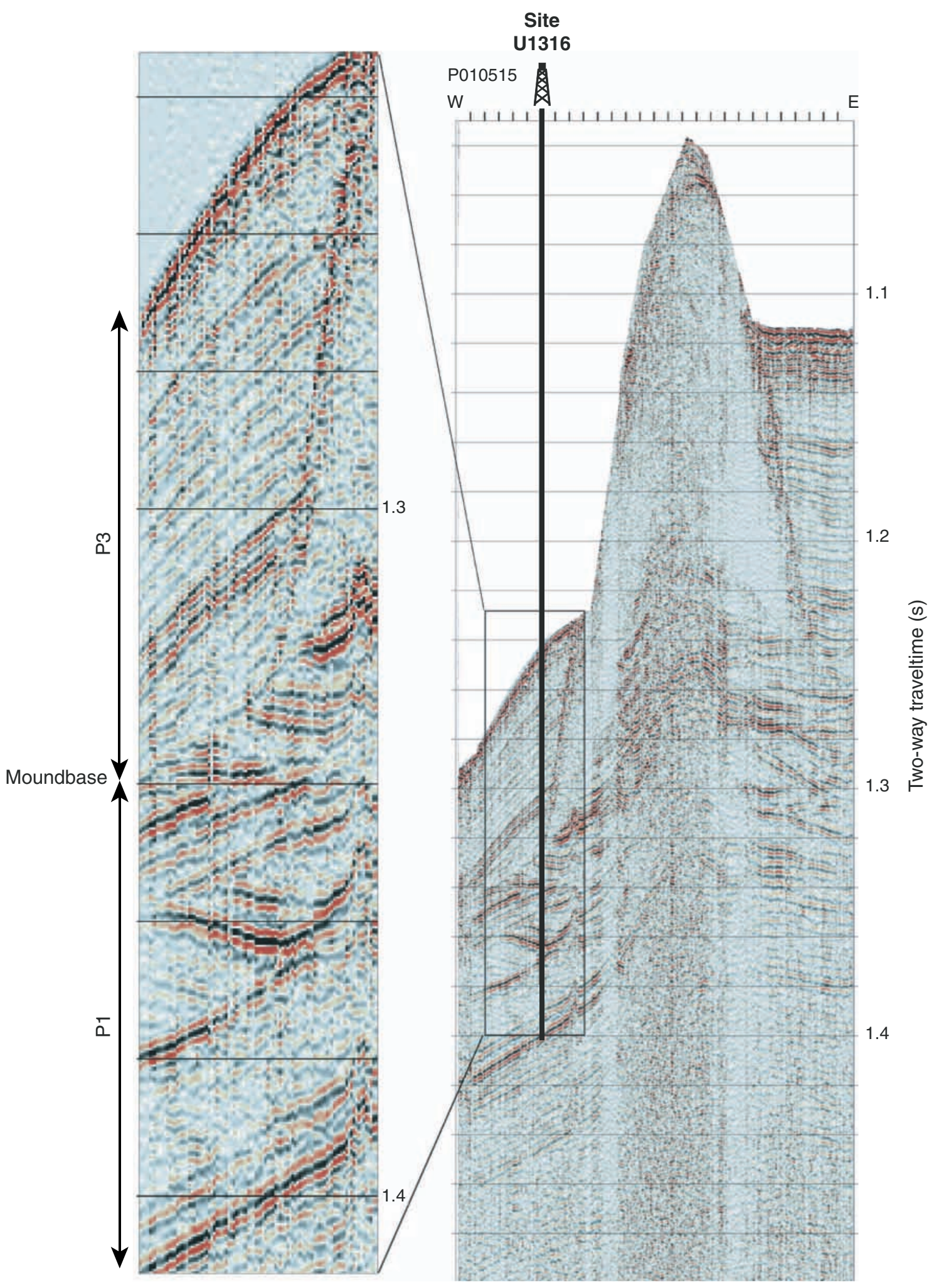


Figure F3. Lithologic column of Hole U1316A. Logs of natural gamma radiation, magnetic susceptibility, and color reflectance are shown to highlight the differences in physical properties between the units. The different units are indicated by the background colors.

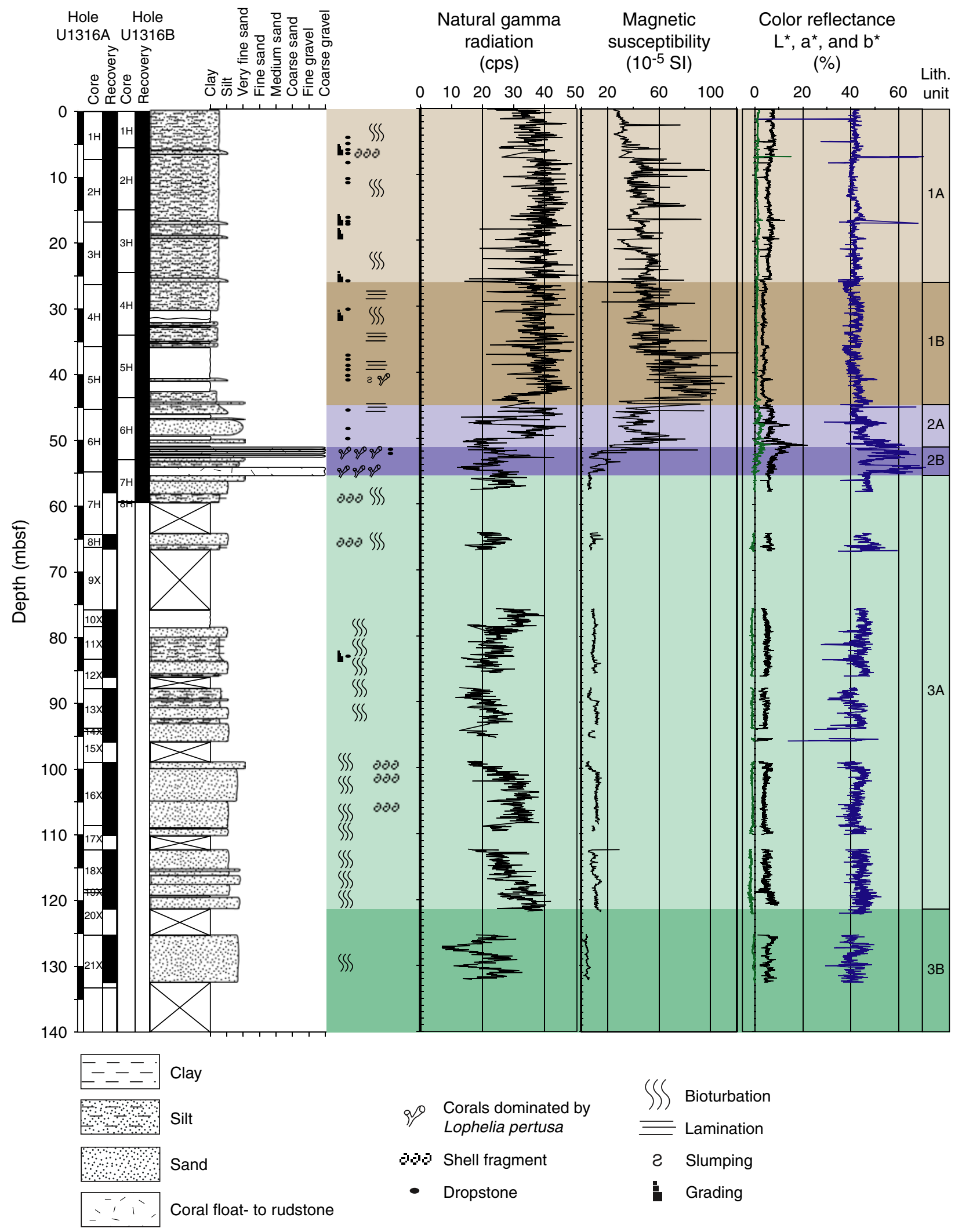


Figure F4. Typical lithology of lithostratigraphic units. Subunit 2B is represented by two photographs because of its high facies variability.

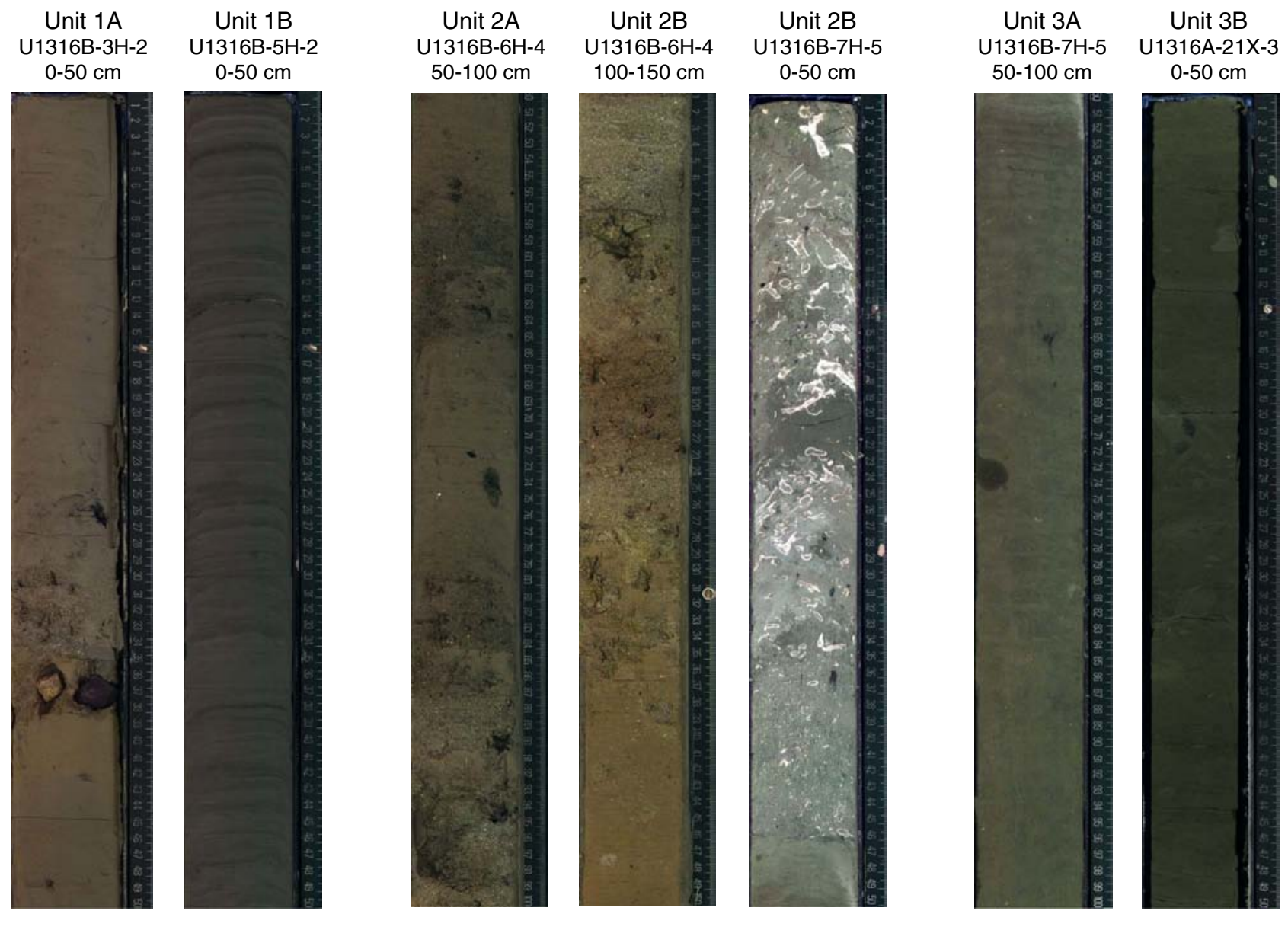


Figure F5. Boundary between Subunits $1 \mathrm{~A}$ and 1B in Holes U1316A and U1316B (307-U1316A-3H-3, $5 \mathrm{~cm}$, and $307-\mathrm{U} 1316 \mathrm{~B}-4 \mathrm{H}-2,30 \mathrm{~cm})$. In both holes, this boundary marks the top of the finely laminated sediments of Subunit 1B.

Hole U1316A

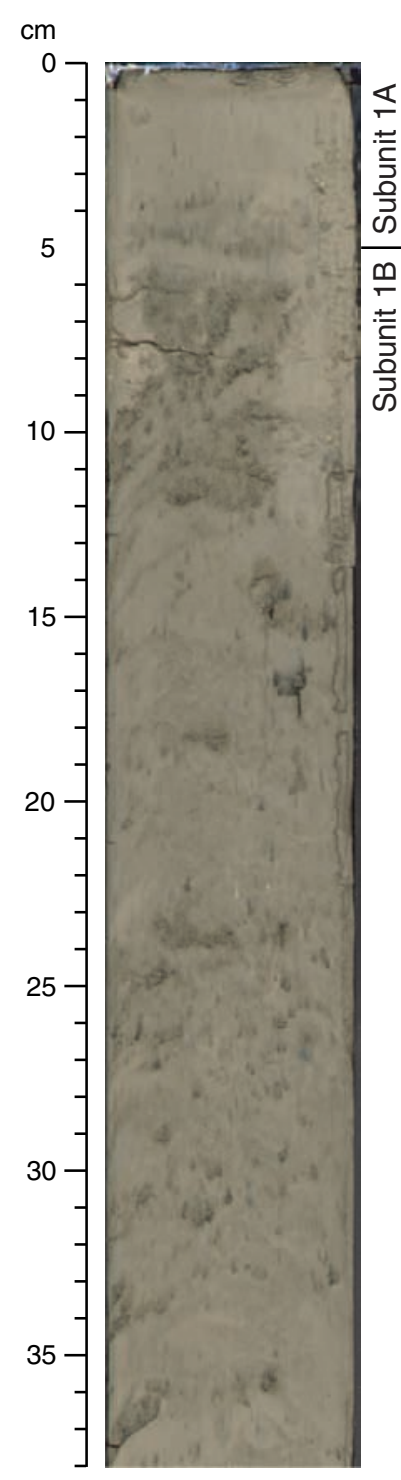

Hole U1316B

$\mathrm{cm}$

0

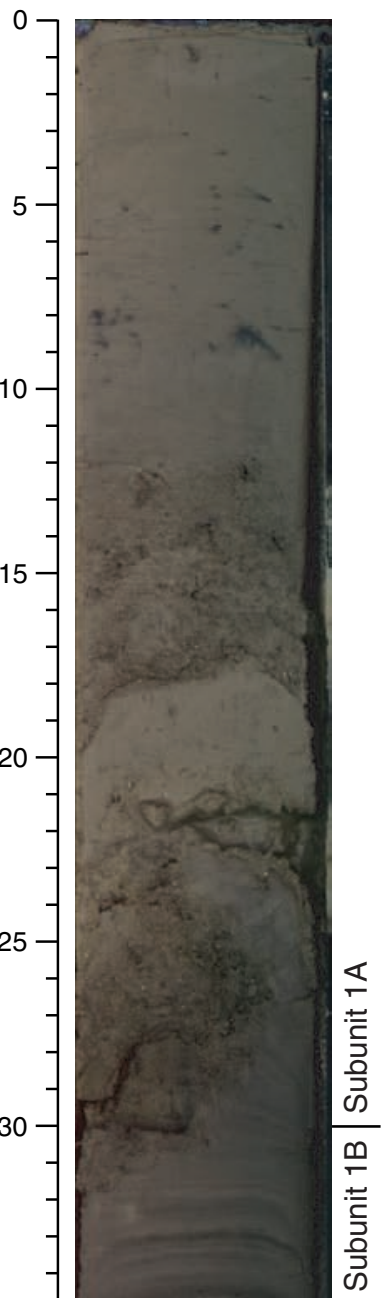

35

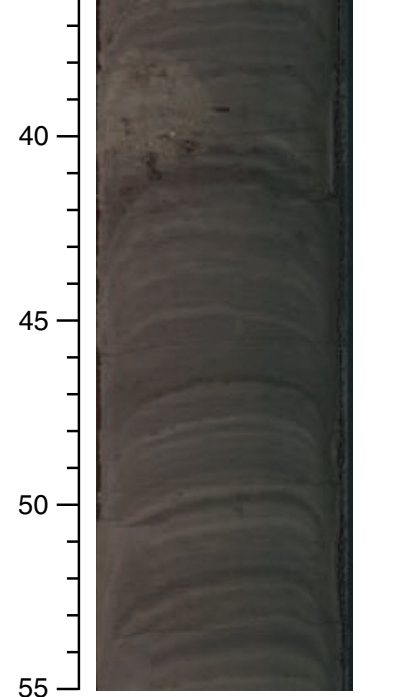


Figure F6. Core section of Subunit 1B including $20 \mathrm{~cm}$ thick soft-sediment deformation structure with silty clay layer incorporated with a calcareous fine to medium sand. Just above this layer, a $7 \mathrm{~cm}$ thick mediumsand to fine-gravel layer is observed. This layer consists of a mixture of dropstones, coral fragments of Lophelia pertusa, and other biodetritus.

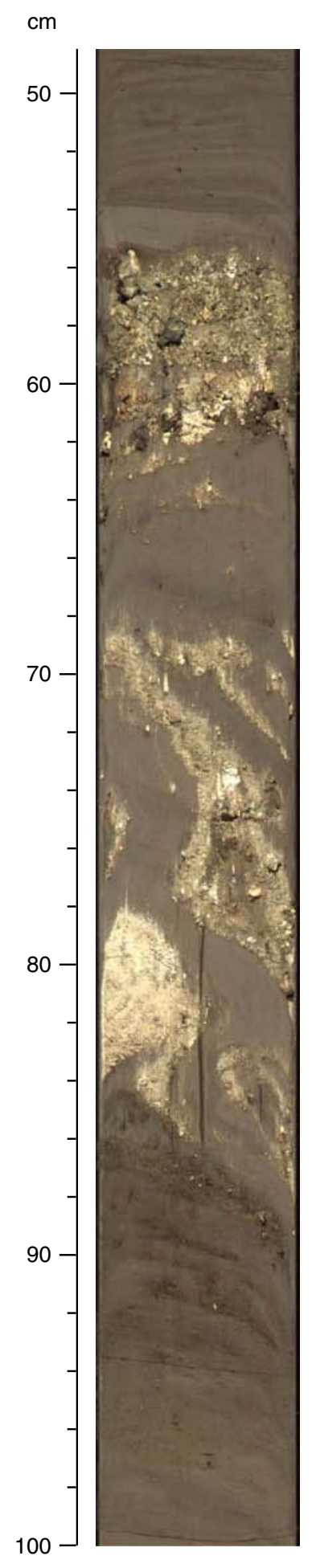


Figure F7. Boundary between Subunits 1B and 2A in Holes U1316A and U1316B (307-U1316A-5H-4, $115 \mathrm{~cm}$, and 307-U1316B-6H-2, $70 \mathrm{~cm})$.

Hole U1316A

$\mathrm{cm}$

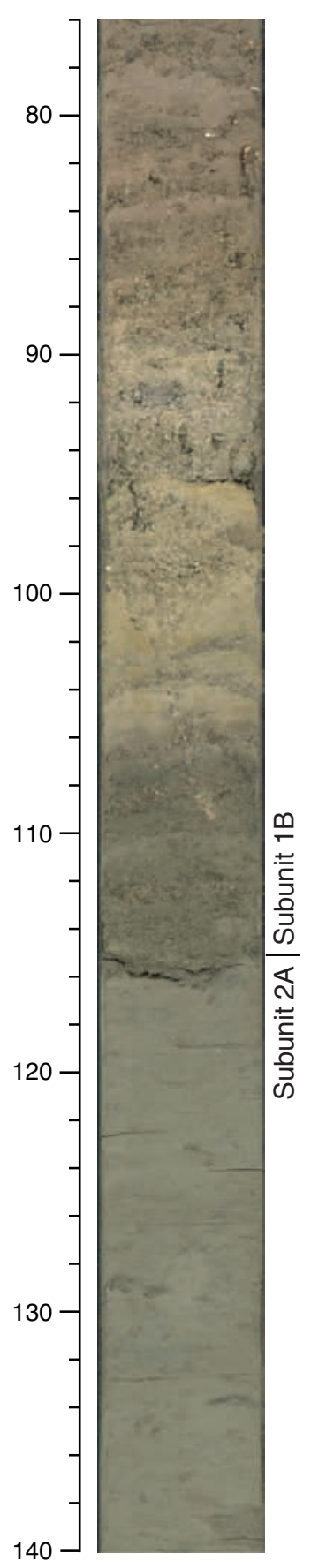

Hole U1316B

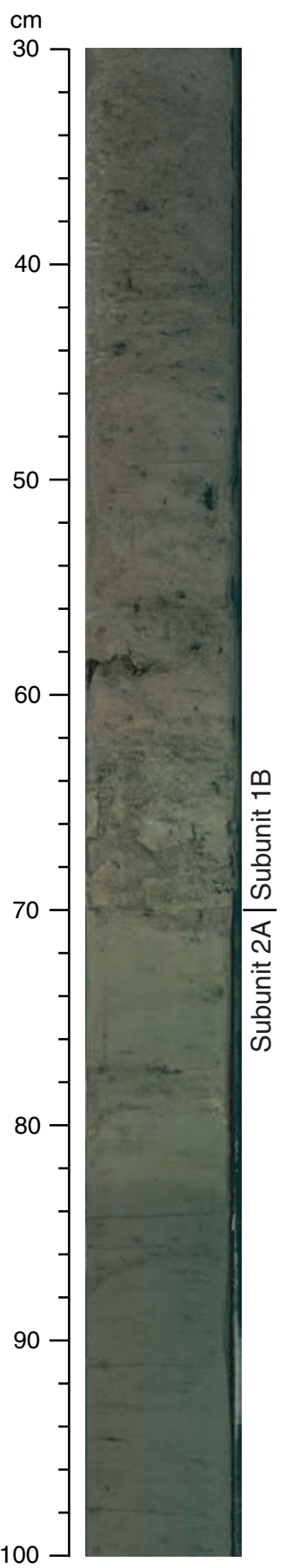


Figure F8. Boundary between Subunit 2A and 2B in Holes U1316A, U1316B, and U1316C (307-U1316A-6H-4, $105 \mathrm{~cm}$; 307-U1316B-7H-1, $45 \mathrm{~cm}$; and 307-U1316C-2R-1, $10 \mathrm{~cm}$ ). The contact in Hole U1316C could be an artifact of drilling disturbance representing an infill core breccia.

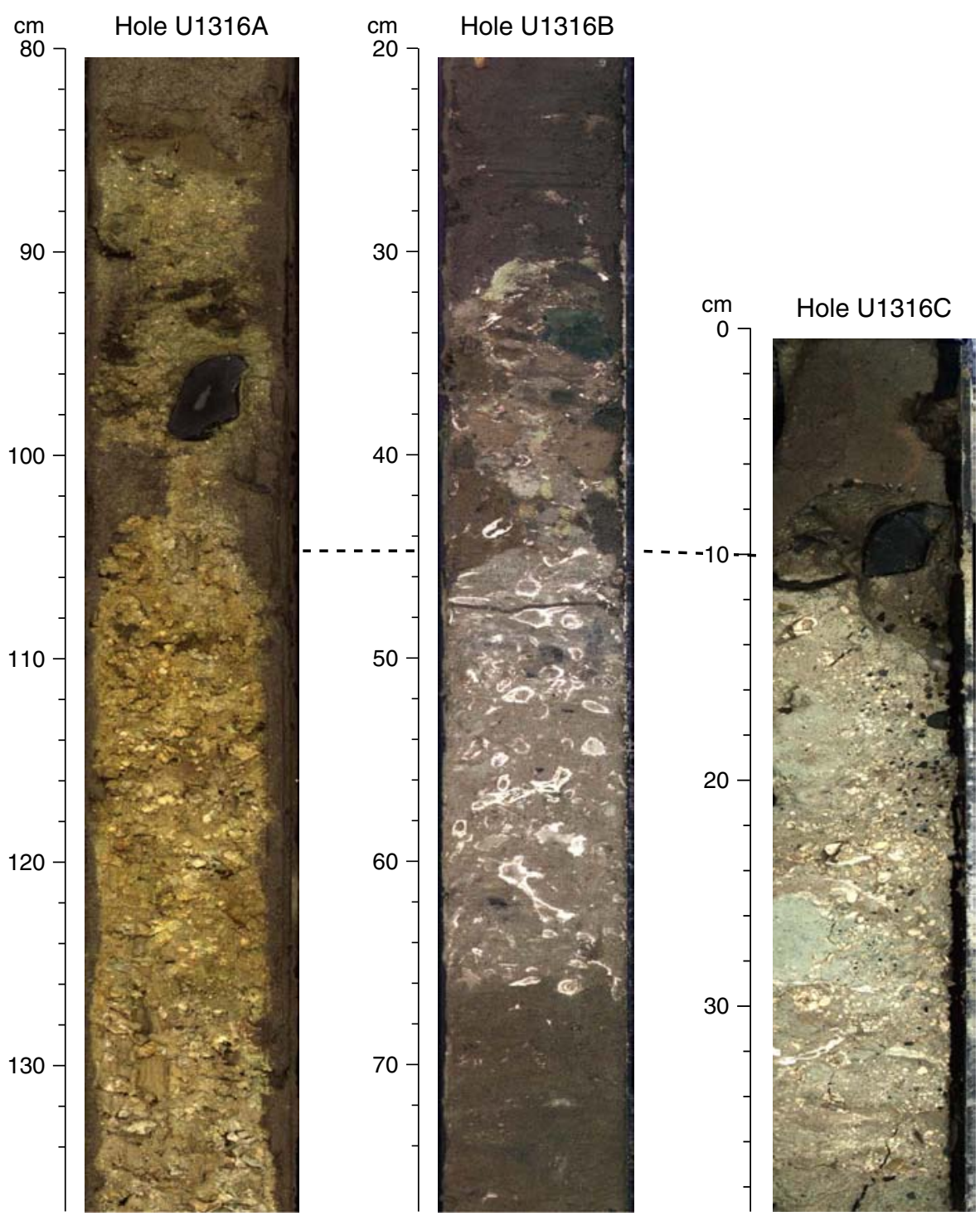


Figure F9. Lithologic column with natural gamma radiation and color reflectance of Unit 2 in Hole U1316A. Note that the six, possibly seven, fining-upward successions of Subunit 2A are correlated with the changes in natural gamma ray signal, as indicated by the shaded area. In Subunit 2B, coral layers are well reflected in the color reflectance data.

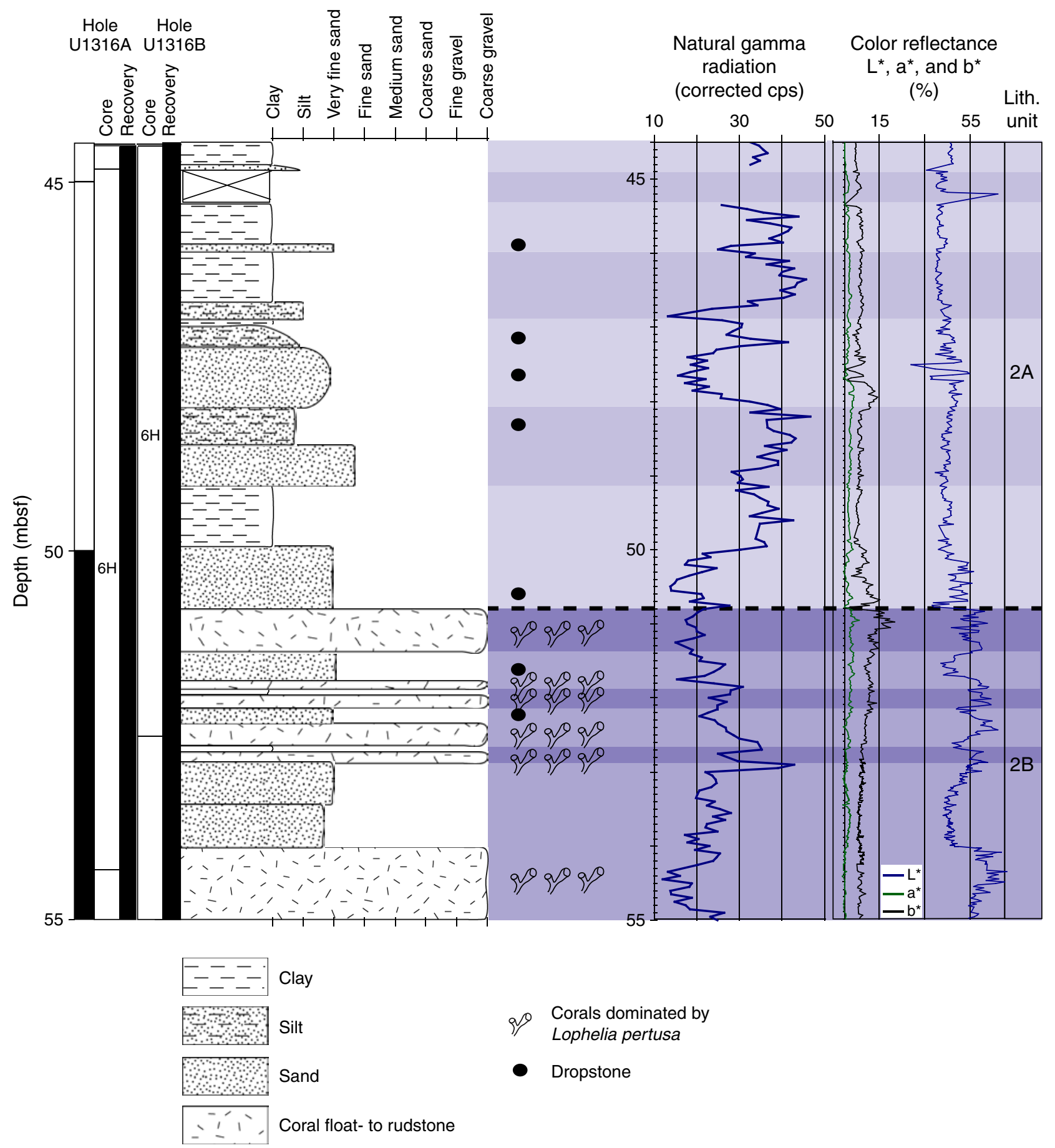


Figure F10. Boundary between Subunit 2B and 3A in Holes U1316A, U1316B, and U1316C (307-U1316A-7H1, $26 \mathrm{~cm}$; 307-U1316B-7H-5, $46 \mathrm{~cm}$; and 307-U1316C-2R-2, $70 \mathrm{~cm})$.

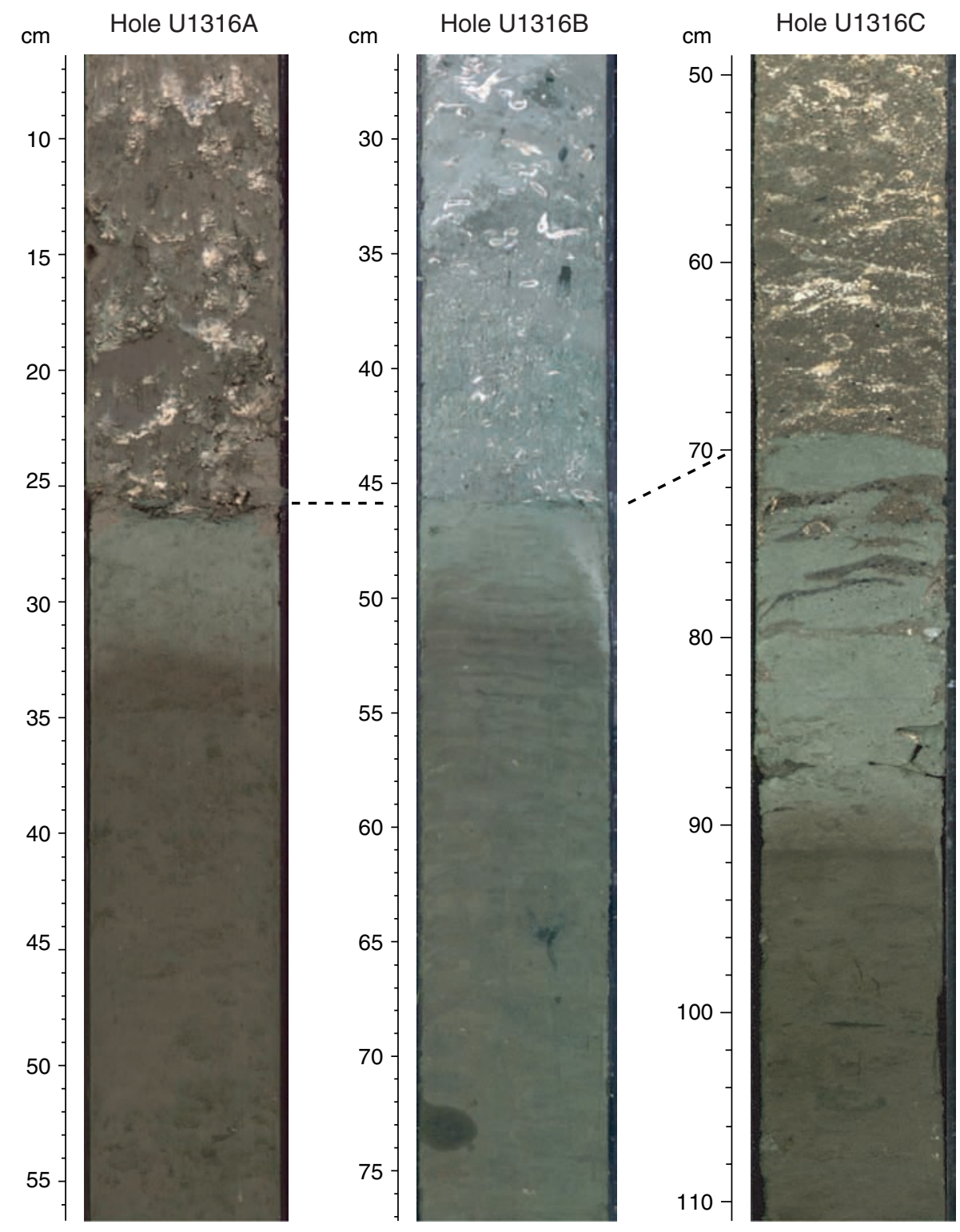


Figure F11. Typical "biscuit" structure within a core drilled with XCB.

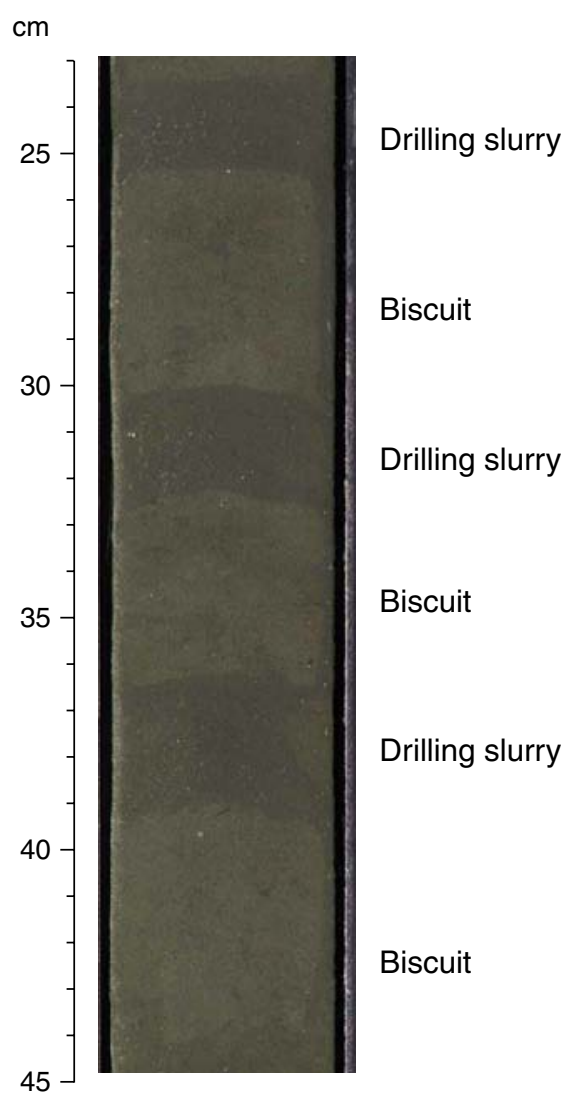


Figure F12. Stratigraphic position of calcareous nannofossil and planktonic foraminifer zones at Site U1316. Wavy lines $=$ hiatus.

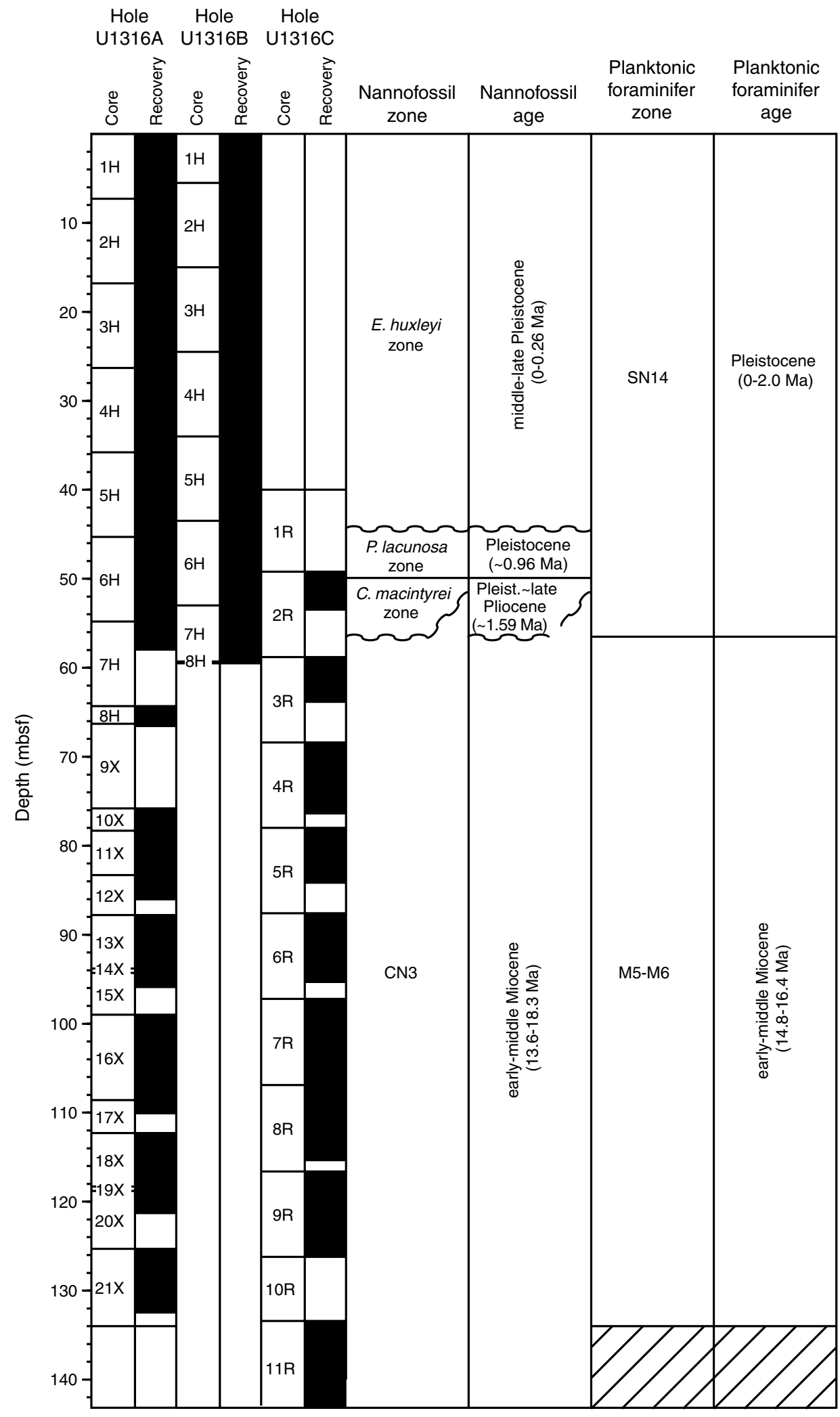


Figure F13. Range chart of age-diagnostic calcareous nannofossil taxa in Hole U1316A.

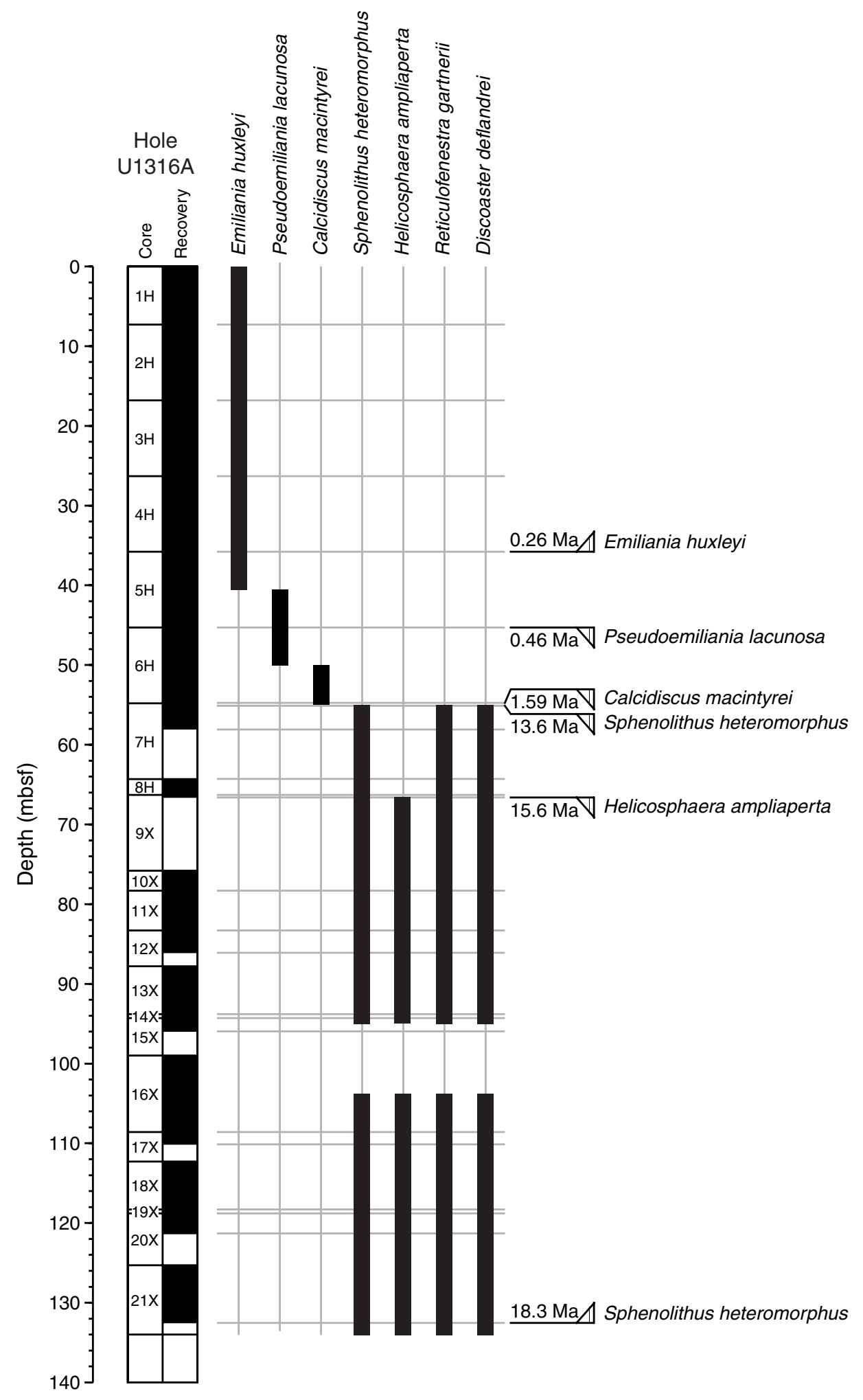


Figure F14. Selected planktonic foraminifer species found during Expedition 307. Red = Pliocene-Holocene species, purple $=$ middle Miocene species, green $=$ Miocene species, blue $=$ cold-water species .

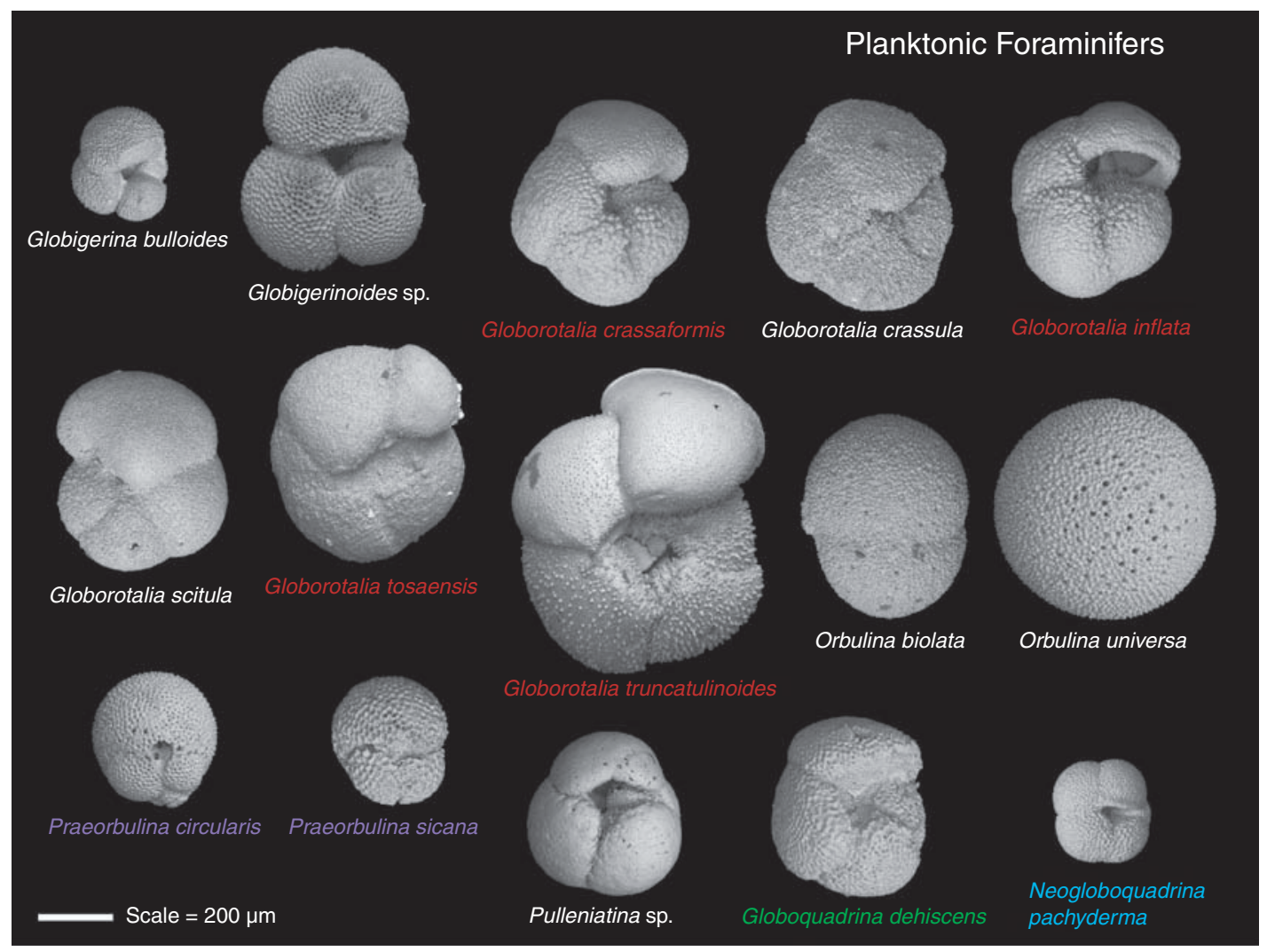


Figure F15. Occurrence of planktonic foraminifer taxa in Hole U1316A. Red = Pliocene-Holocene species, purple $=$ middle Miocene species, green $=$ Miocene species .

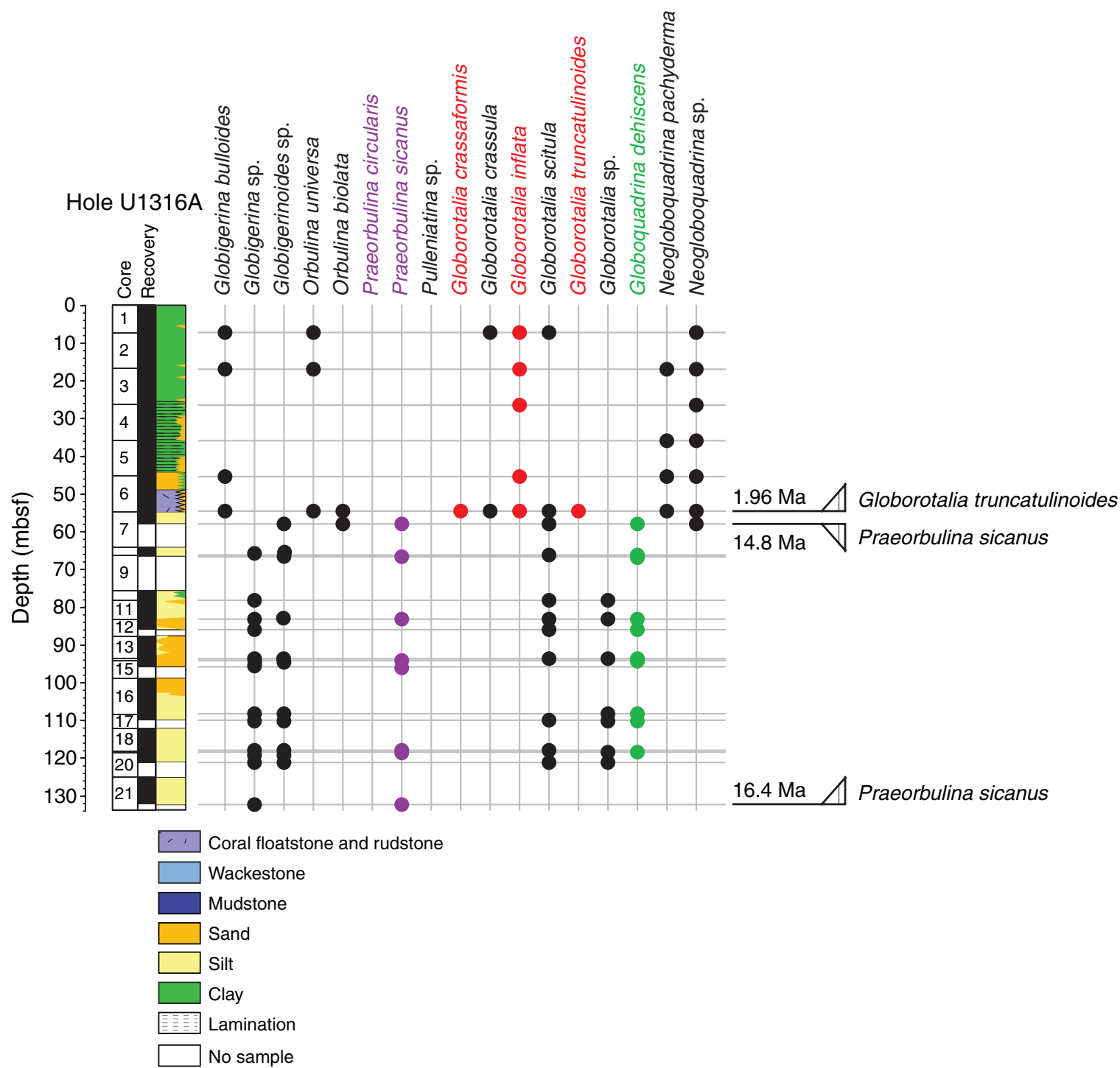


Figure F16. Occurrences of planktonic foraminifers from the core catcher of each core in Hole U1316A. Note that the cold-water species Neogloboquadrina pachyderma is common in lithostratigraphic Units 1 and 2 of Hole U1316A, but rare in Hole U1317A (see Fig. F10 in the "Site U1317" chapter).

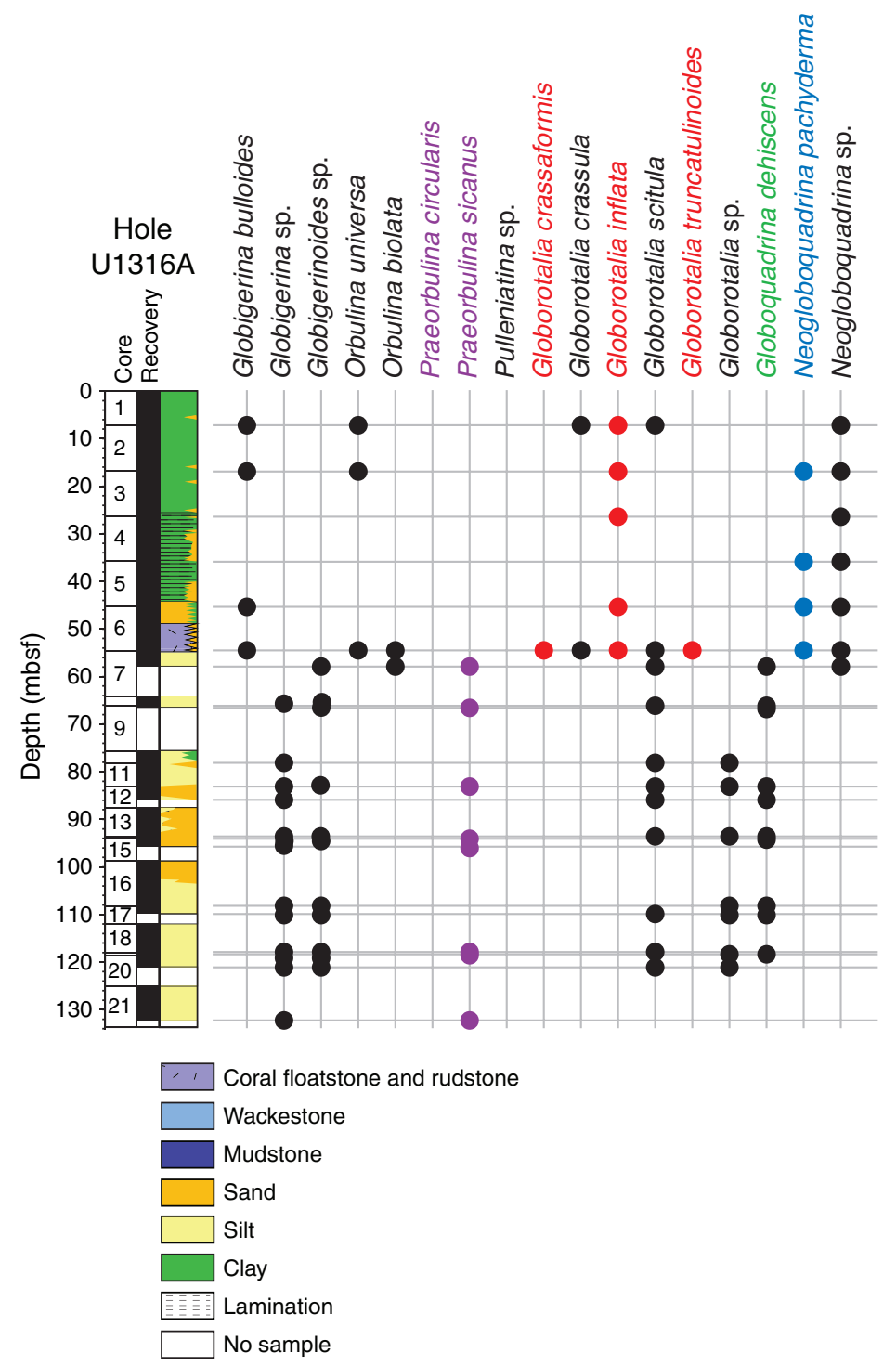


Figure F17. Benthic foraminifer species found in Expedition 307. Green $=$ shallow-water species (Elphidium excavatum, Islandiella norcrossi), orange = species associated with cold seepage (Bulimmina marginata).

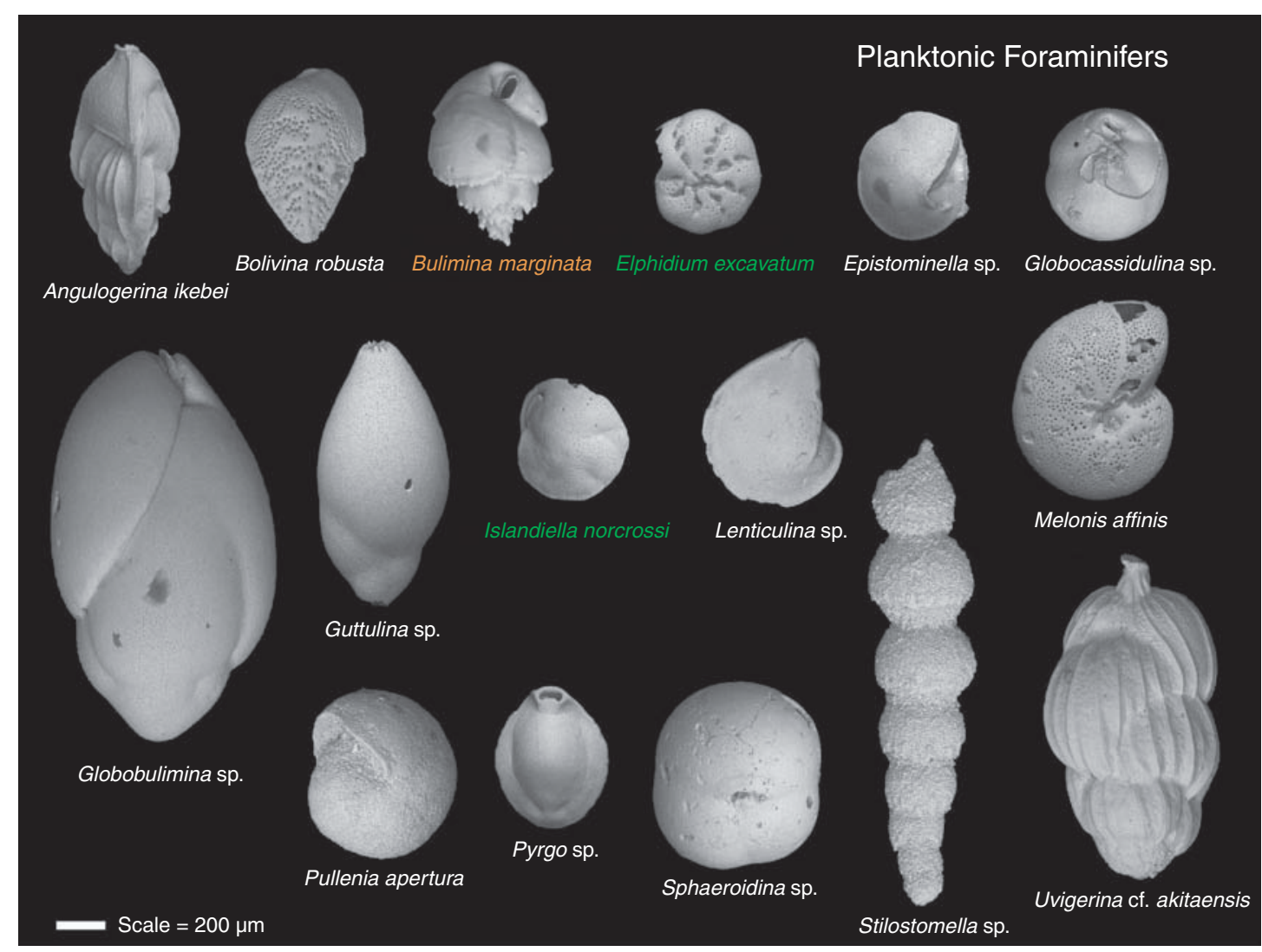


Figure F18. Occurrences of benthic foraminifers from core catcher of each core in Hole U1316A. Note that species associated with cold seepage. (Bulimmina marginata, Bulimmina sp.) are common in Hole U1316A, but rare in Hole U1317A (see Fig. F11 in the "Site U1317" chapter).

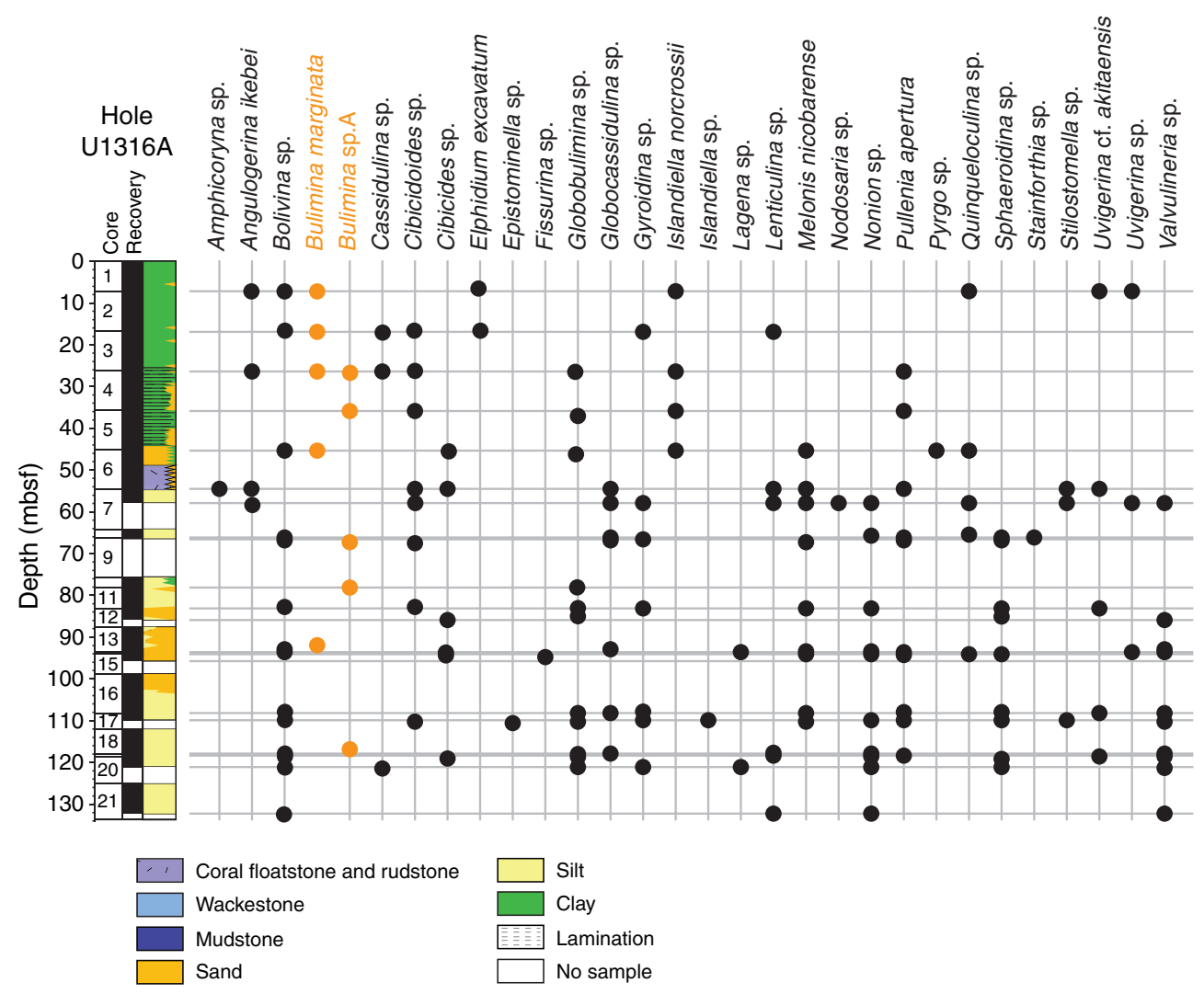


Figure F19. Stepwise AF demagnetization at 5, 10, 15, and $20 \mathrm{mT}$ of Section 307-U1316A-1H-1 at (A) 0.85 mbsf and (B) 0.55 mbsf. Left panels show orthogonal projection of endpoints of the magnetization vector. Open symbols $=$ projection on vertical plane, solid symbols $=$ projection on horizontal plane. Middle panels show change in magnetization intensity during AF demagnetization. Right panels show equal area projection of the magnetization vector during demagnetization.

A

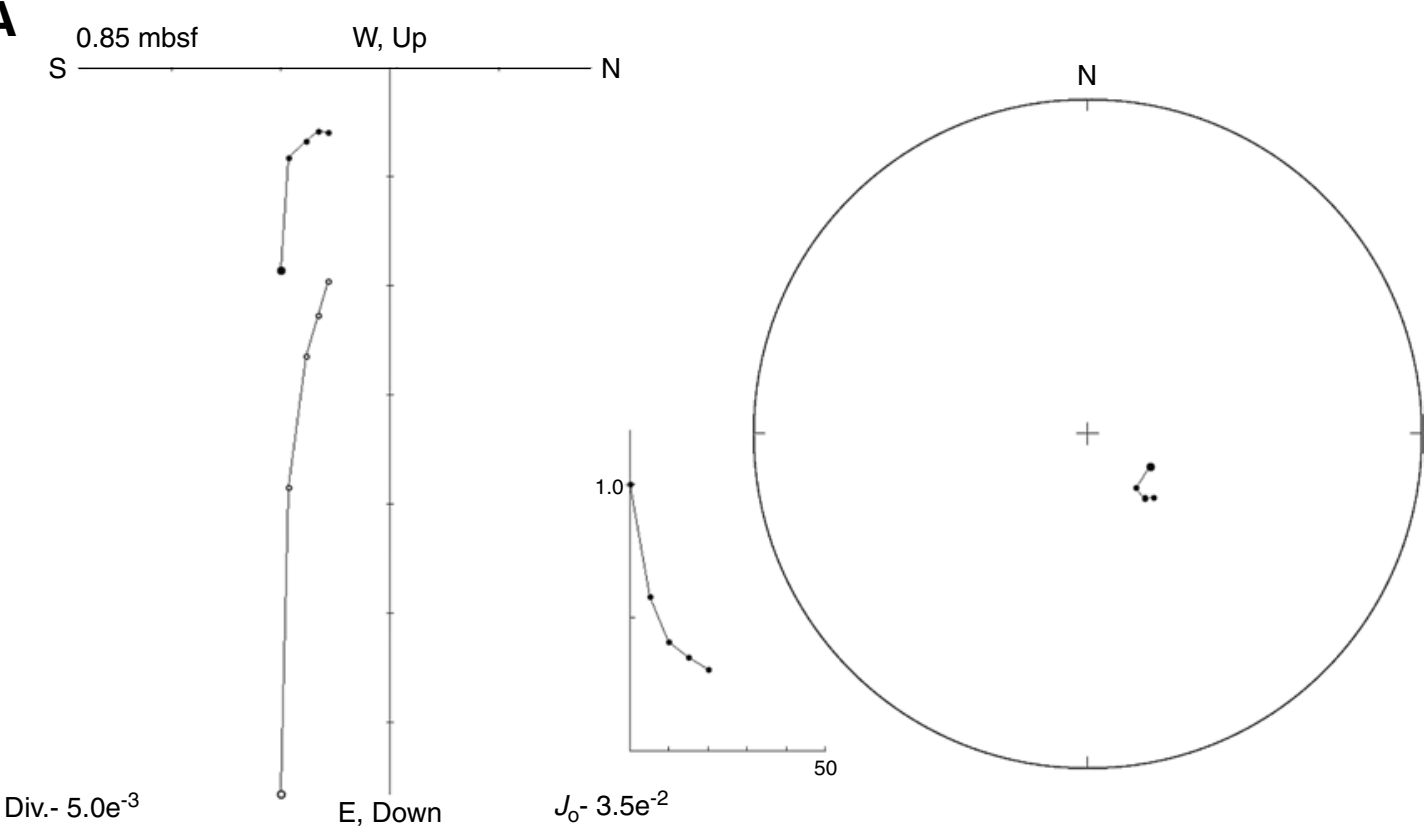

B

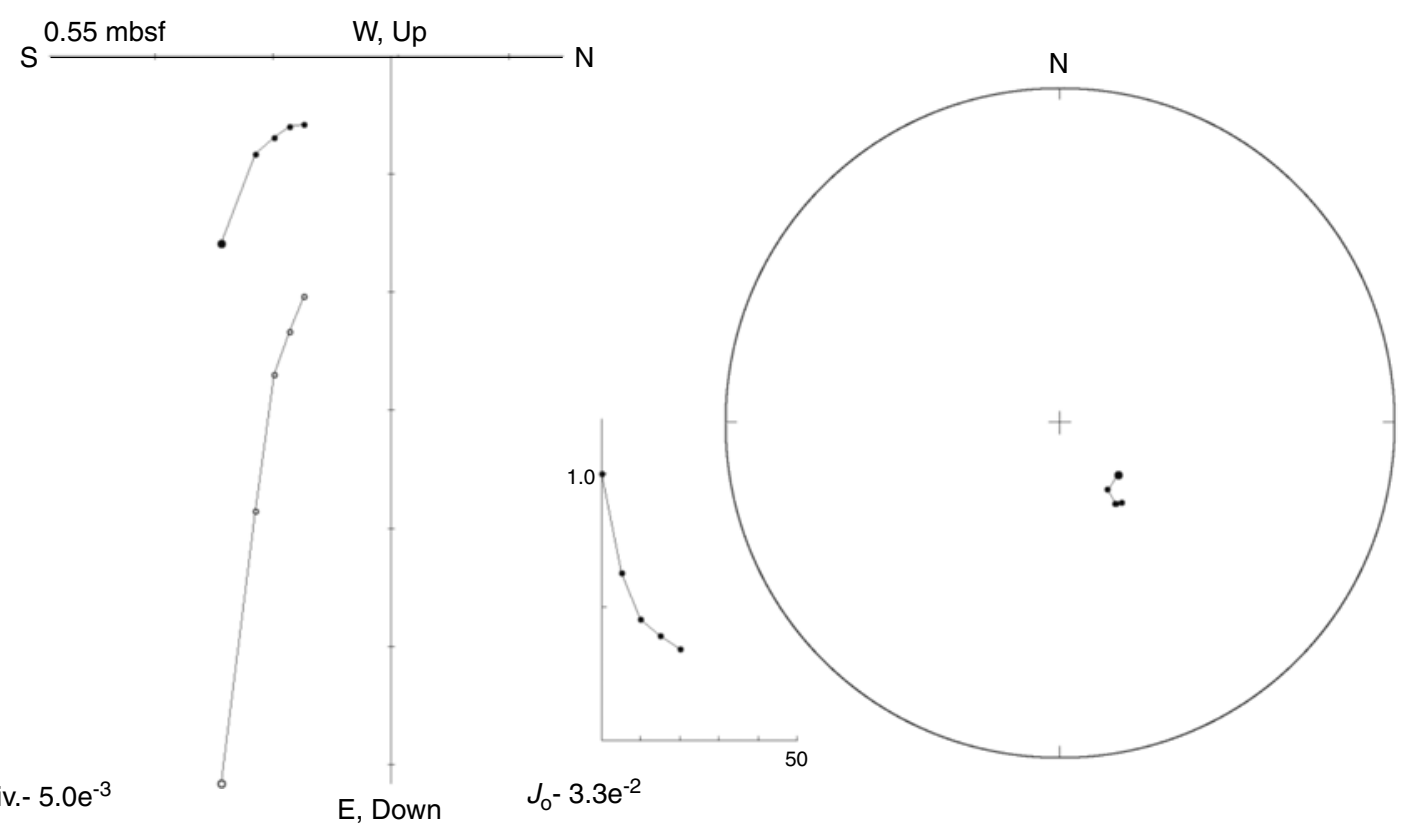


Figure F20. Inclination and declination of magnetization vector vs. depth after AF demagnetization at peak fields of $20 \mathrm{mT}$.

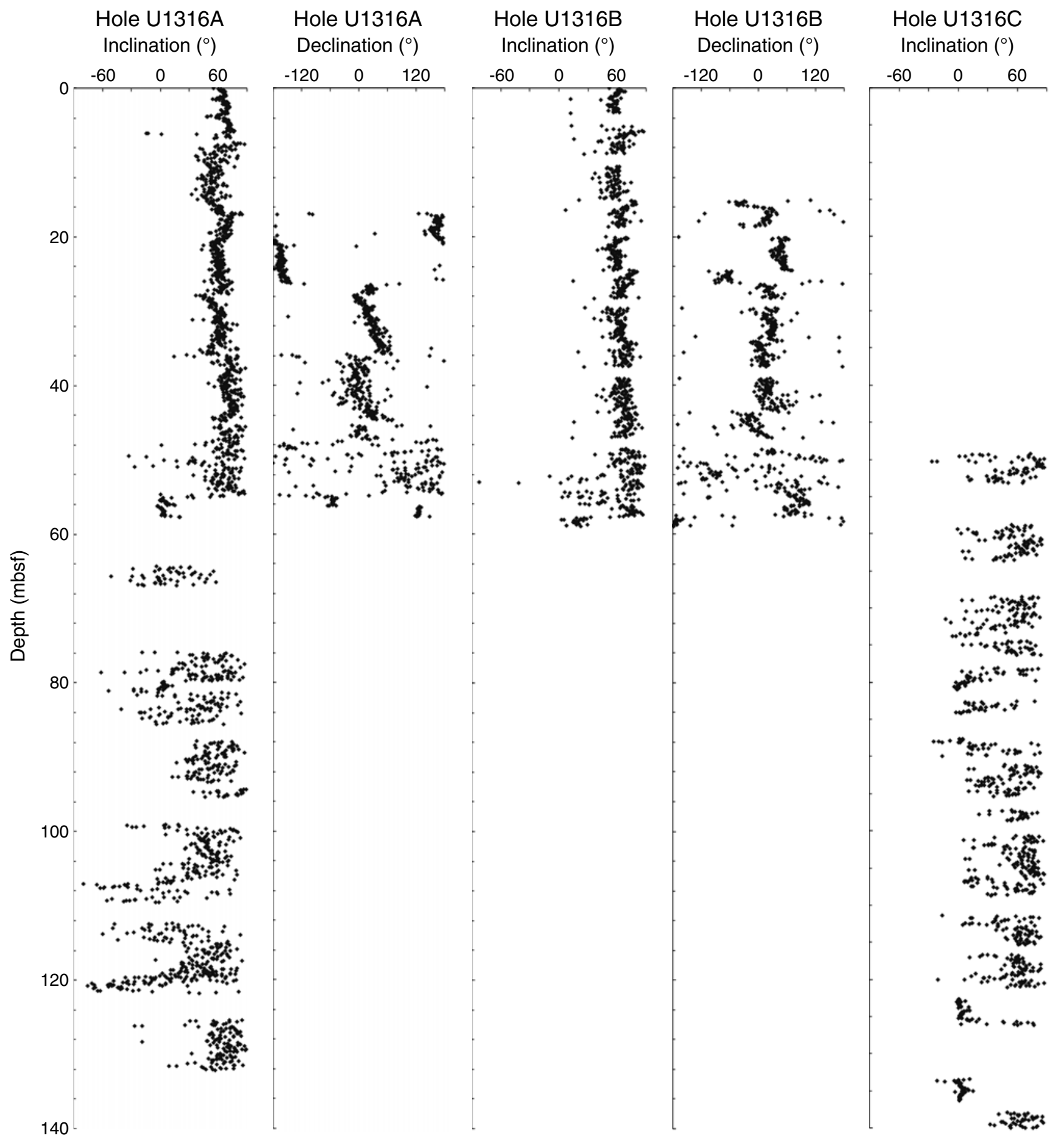


Figure F21. Magnetization intensity (after alternating-field demagnetization at peak field of $20 \mathrm{mT}$ ), magnetic susceptibility (MS), and intensity/MS vs. depth.

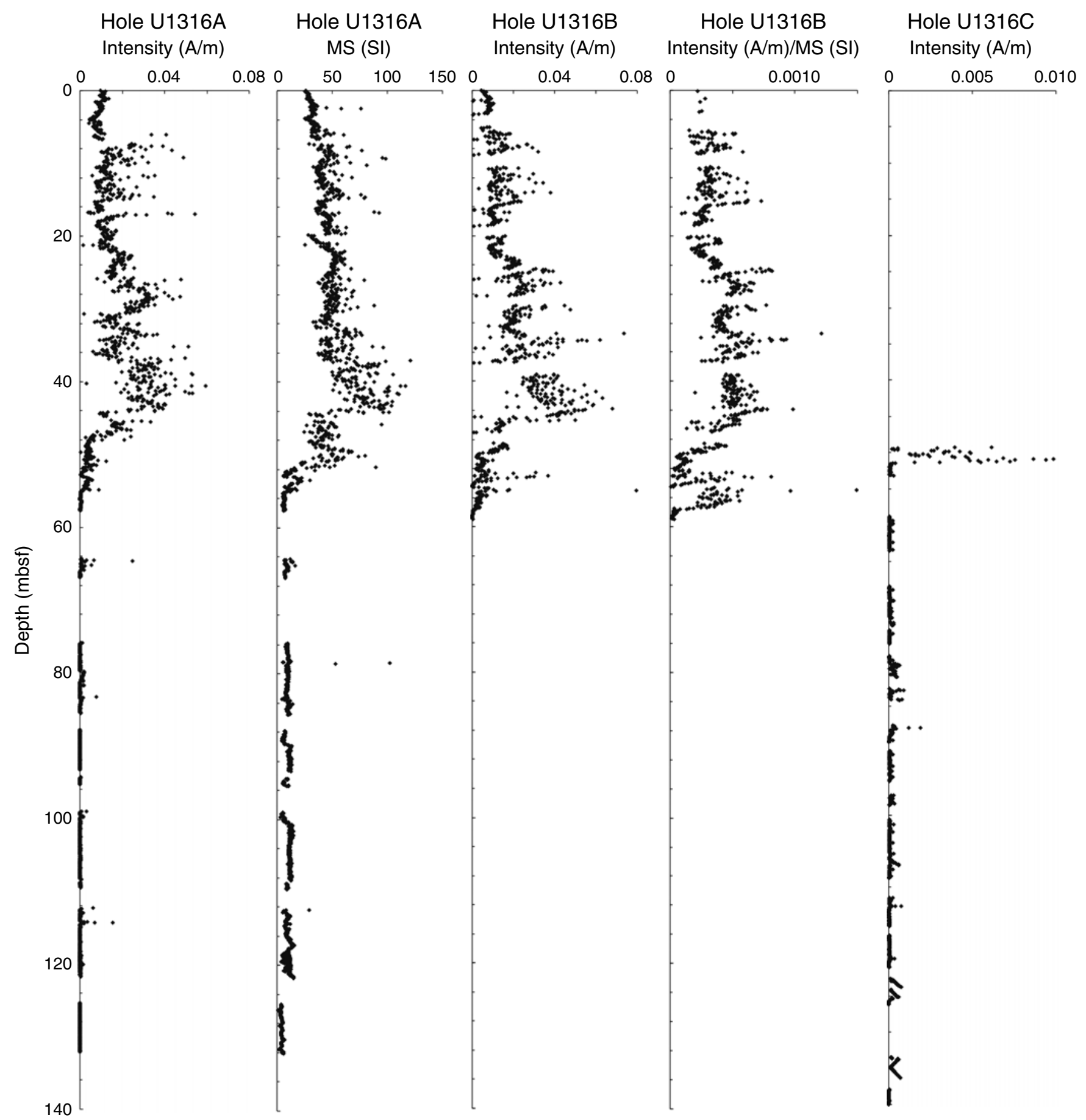


Figure F22. Concentrations of dissolved chemical species and adsorbed gas vs. depth in interstitial waters. A. Strontium. B. Lithium. C. Boron. D. Alkalinity. E. Dissolved inorganic carbon (DIC). F. Sulfate. G. Iron. H. Manganese. I. Ammonium. J. Dissolved methane. K. Adsorbed methane. L. Dissolved ethane. Solid circles = Hole U1316A, open diamonds = Hole U1316B, open squares $=$ Hole U1316C.
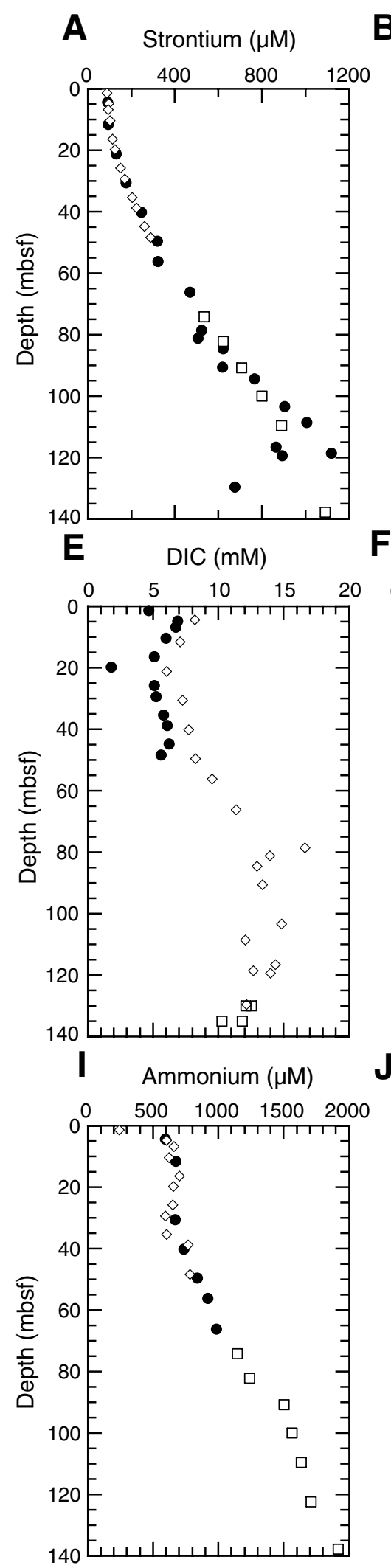

B Lithium $(\mu \mathrm{M})$

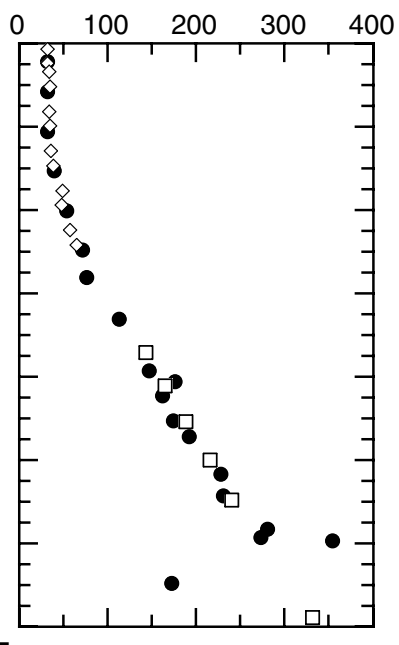

$F$
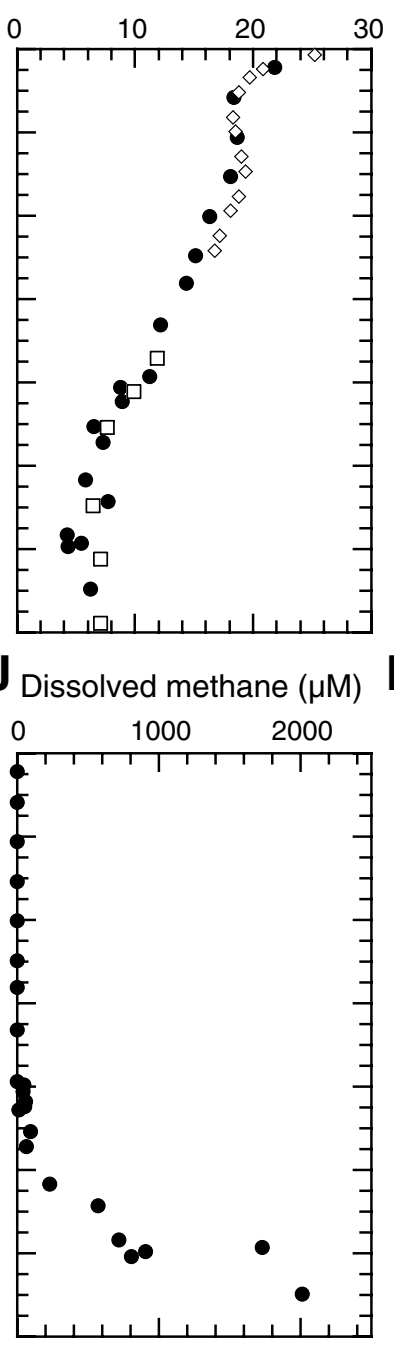

C Boron $(\mu \mathrm{M})$
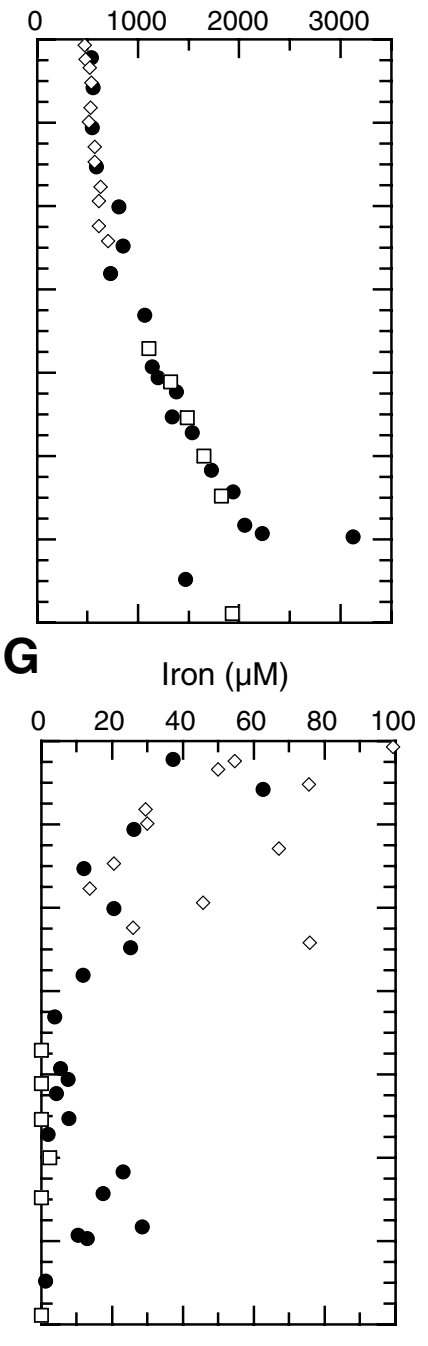

$\mathbf{K}_{\mathrm{A}}$

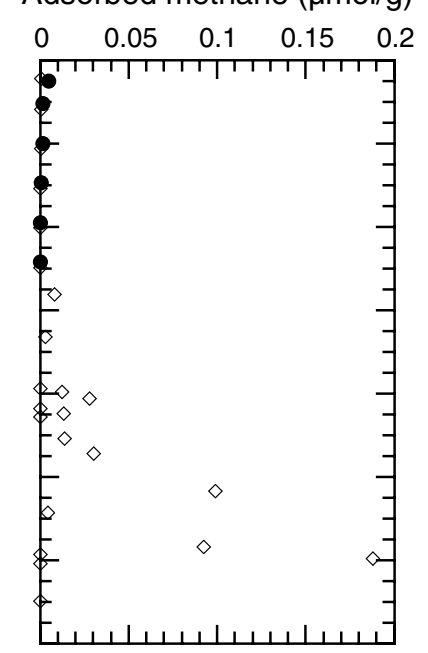

D Alkalinity (mM)
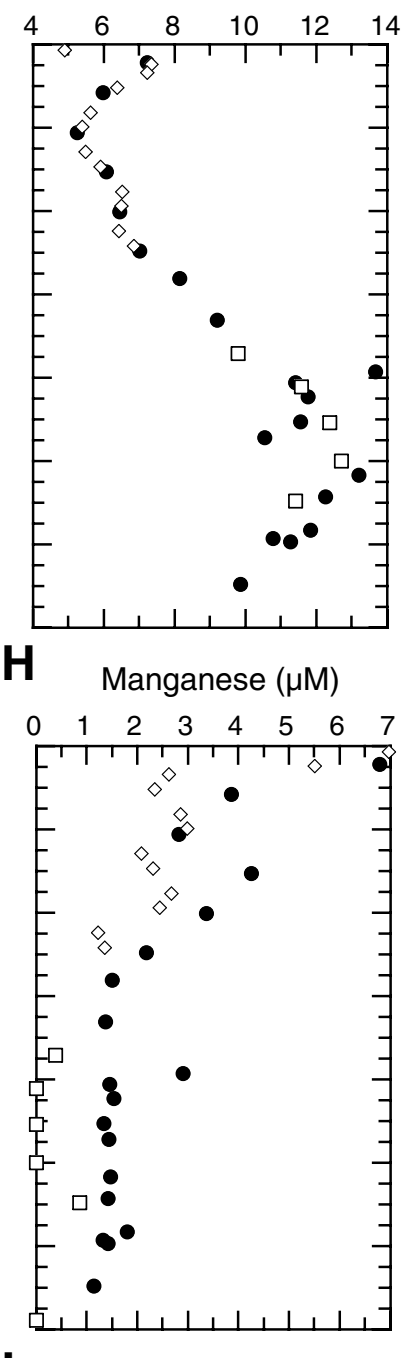

$\mathbf{L}$ Dissolved ethane $(\mu \mathrm{M})$

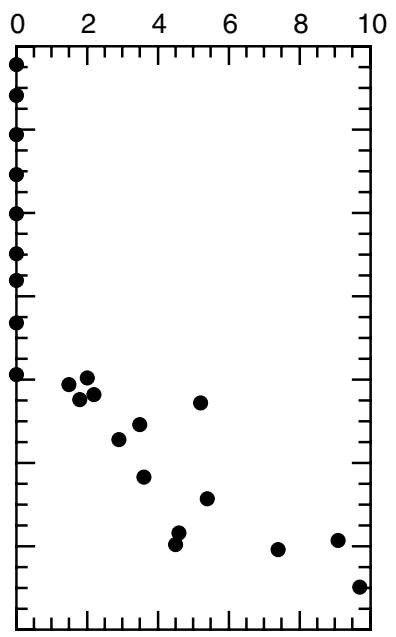


Figure F23. Plots showing covariance between (A) lithium and strontium and (B) boron and strontium. Solid circles $=$ Hole U1316A, open diamonds $=$ Hole U1316B.
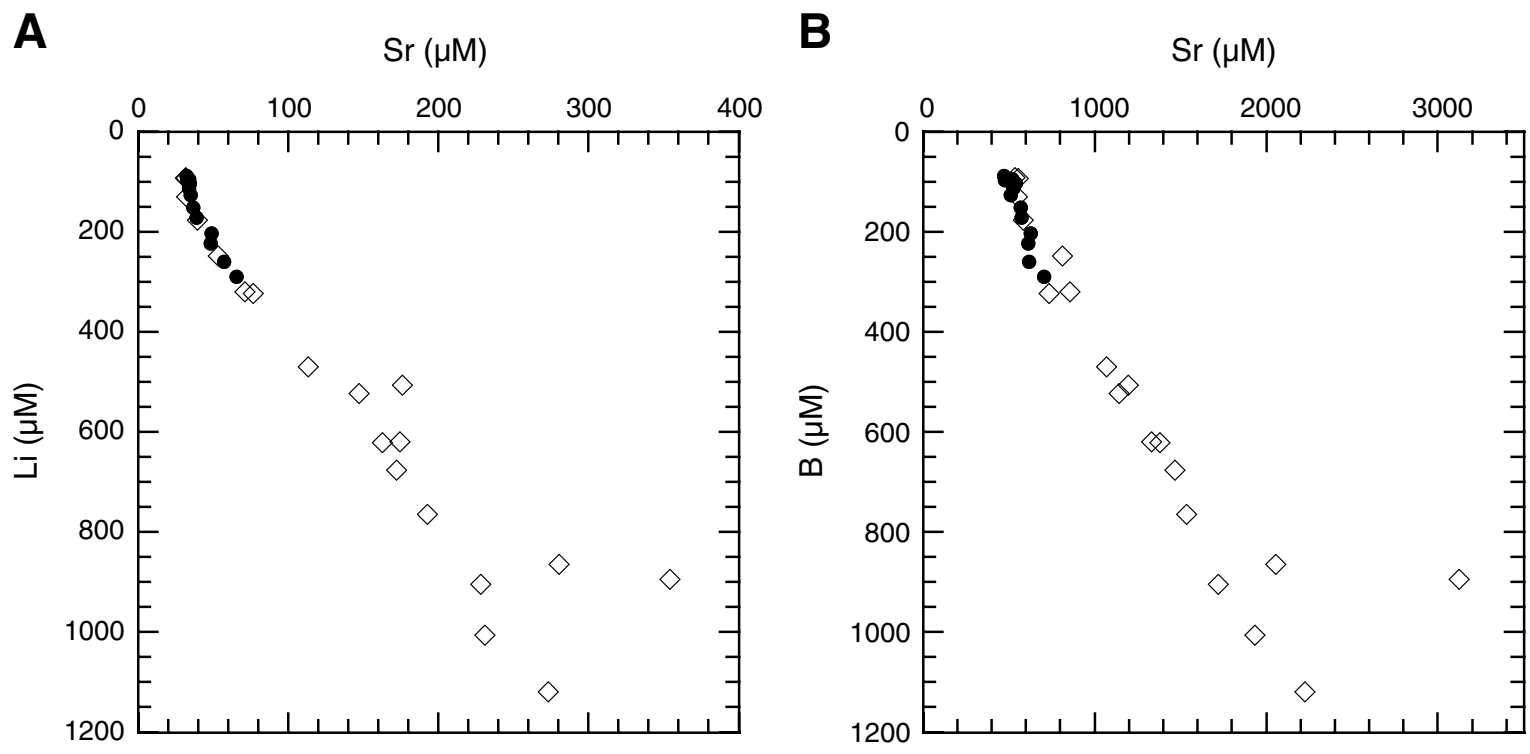
Figure F24. Concentrations vs. depth. A. Calcium. B. Magnesium. Solid circles = Hole U1316A, open diamonds = Hole U1316B.

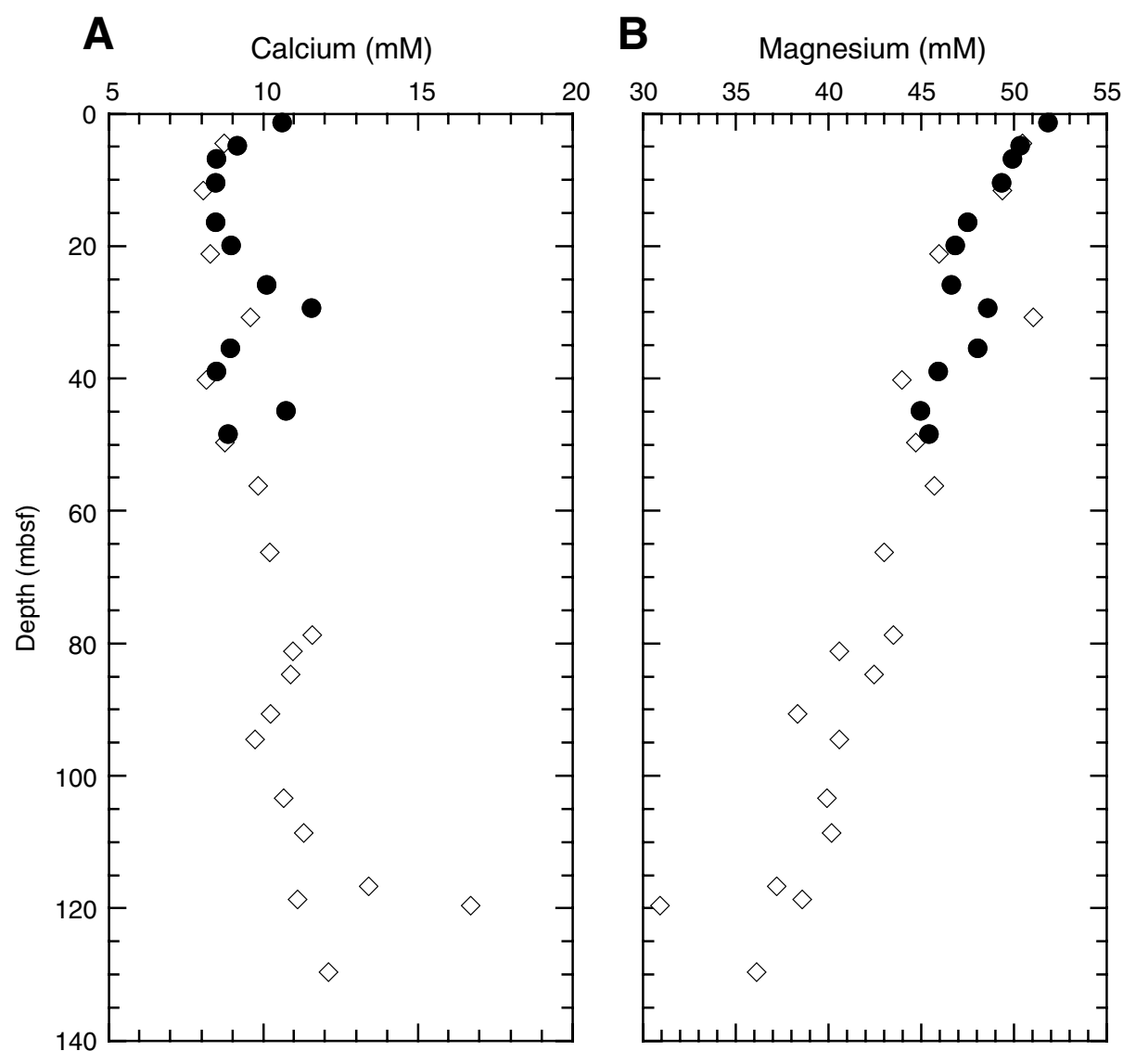


Figure F25. Carbonate content vs. depth.

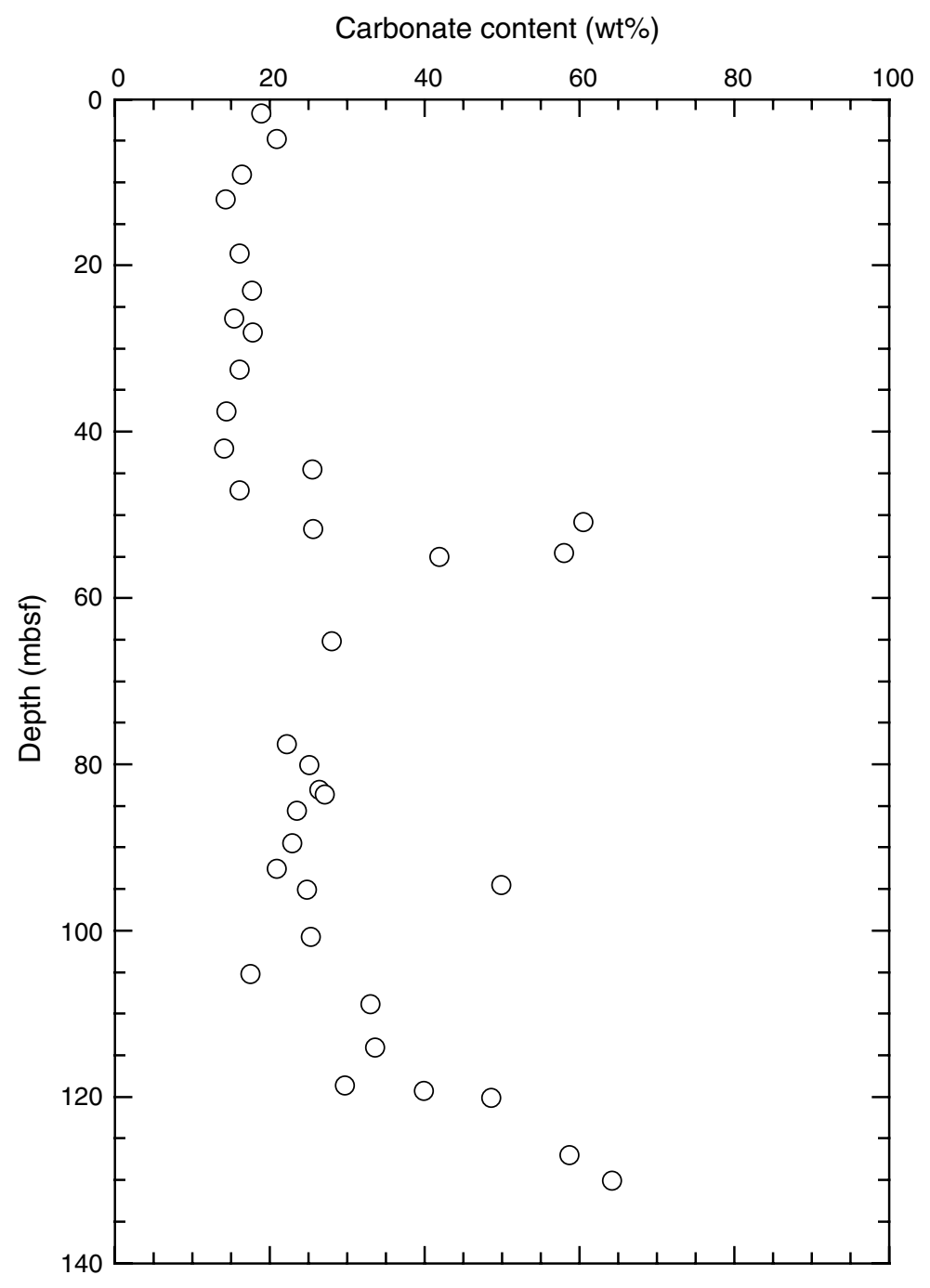


Figure F26. Graphical representation of syringe-sampling and analysis program for the MBIO core sections from Hole U1316A. See Table T4 in the "Methods" chapter for explanation of sampling codes.

\begin{tabular}{|c|c|c|c|c|c|c|}
\hline 307-U1316A & \multicolumn{4}{|c|}{ CATWALK } & & \\
\hline CURATORS CODE & IW & AODC & $\mathrm{HS}$ & $\mathrm{CH} 4$ & \multicolumn{2}{|c|}{ Core depth } \\
\hline approx. sample size $(\mathrm{cm})$ & 10 & 1 & 5 & 5 & \multirow{2}{*}{\multicolumn{2}{|c|}{$\mathrm{mbsf}$}} \\
\hline Sample type & WRC & 1 syringe & 1 syringe & 1 syringe & & \\
\hline Core & $140-150 \mathrm{~cm}$ & \multicolumn{3}{|c|}{$135-140 \mathrm{~cm}$} & top & bottom \\
\hline $1 \mathrm{H}$ & 1 & 2 & 1 & 1 & 0.00 & 7.30 \\
\hline $2 \mathrm{H}$ & 1 & 1 & 1 & 1 & 7.30 & 16.80 \\
\hline $3 \mathrm{H}$ & 1 & 1 & 1 & 1 & 16.80 & 26.30 \\
\hline $4 \mathrm{H}$ & 1 & 1 & 1 & 1 & 26.30 & 35.80 \\
\hline $5 \mathrm{H}$ & 1 & 1 & 1 & 1 & 35.80 & 45.30 \\
\hline $6 \mathrm{H}$ & 1 & 1 & 1 & 1 & 45.30 & 54.80 \\
\hline $7 \mathrm{H}$ & 1 & 1 & 1 & 1 & 54.80 & 64.30 \\
\hline $8 \mathrm{H}$ & 1 & 1 & 1 & 1 & 64.30 & 75.80 \\
\hline $10 x$ & 1 & 1 & 1 & 1 & 75.80 & 78.30 \\
\hline $11 X$ & 1 & 1 & 1 & 1 & 78.30 & 83.30 \\
\hline $12 X$ & 1 & 1 & 1 & 1 & 83.30 & 87.80 \\
\hline $13 X$ & 1 & 1 & 1 & 1 & 87.80 & 94.30 \\
\hline $15 X$ & 1 & 1 & 1 & 1 & 94.30 & 99.00 \\
\hline $16 X$ & 1 & 1 & 1 & 1 & 99.00 & 108.60 \\
\hline $17 X$ & 1 & 1 & 1 & 1 & 108.60 & 112.30 \\
\hline $18 X$ & 1 & 1 & 1 & 1 & 112.30 & 118.80 \\
\hline $20 X$ & 1 & 1 & 1 & 1 & 118.80 & 125.30 \\
\hline $21 X$ & 1 & 1 & 1 & 1 & 125.30 & 134.00 \\
\hline TOTAL & 18 & 19 & 18 & 18 & 73 & Samples \\
\hline
\end{tabular}


Figure F27. Graphical representation of subsampling and analysis program for the MBIO core sections in Hole U1316B. The sequence of subsections runs from the top of the core (right) toward the bottom (left). WRC = whole-round core. See Table T4 in the "Methods" chapter for explanation of sampling codes.

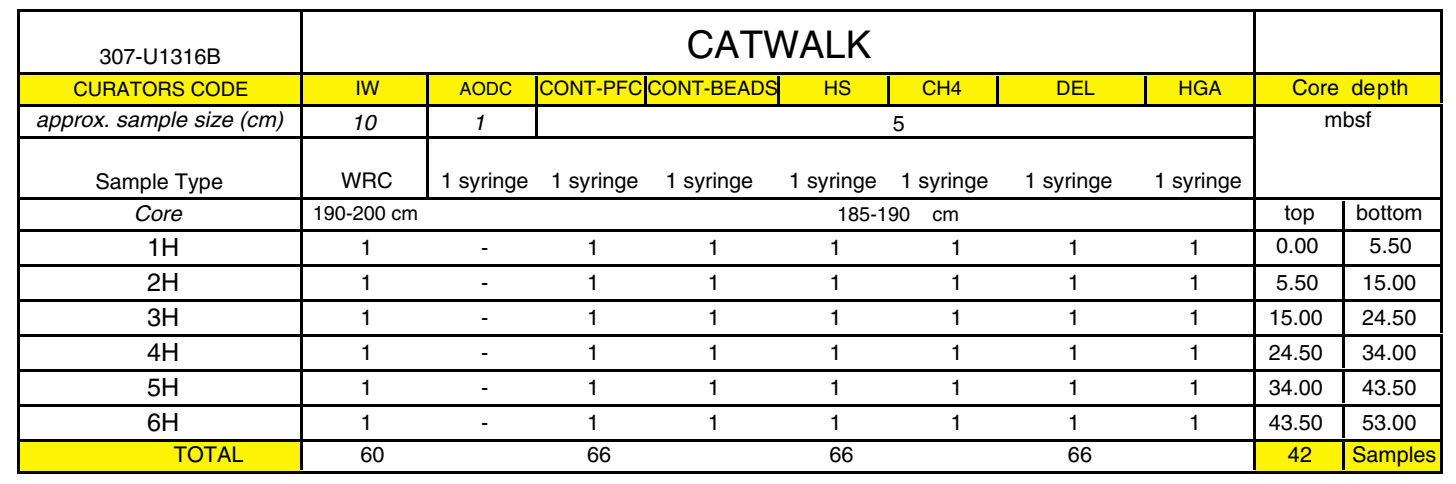

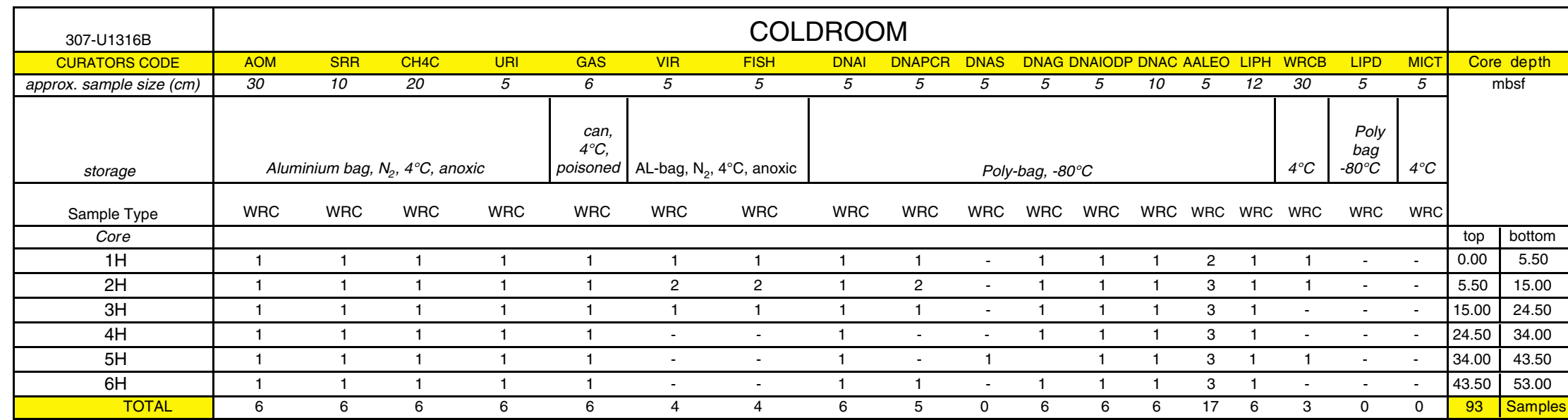


Figure F28. Graphical representation of subsampling and analysis program for the MBIO core sections in Hole U1316C. The sequence of subsections runs from the top of the core (right) toward the bottom (left). WRC = whole-round core. See Table T4 in the "Methods" chapter for explanation of sampling codes.

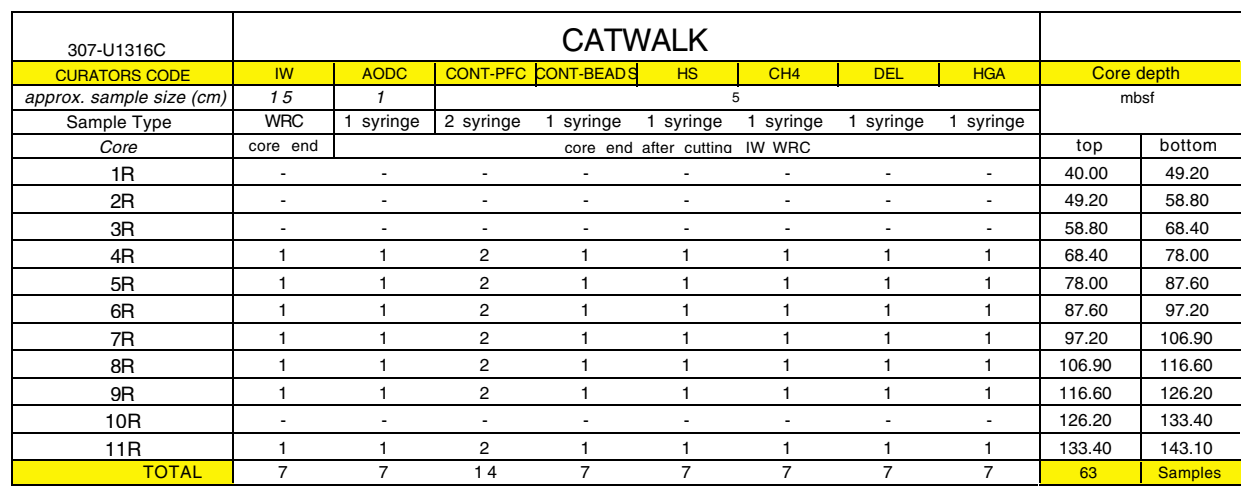

\begin{tabular}{|c|c|c|c|c|c|c|c|c|c|c|c|c|c|c|c|c|c|c|c|c|}
\hline $307-\mathrm{U} 1316 \mathrm{C}$ & \multicolumn{18}{|c|}{ COLDROOM } & \multirow{2}{*}{\multicolumn{2}{|c|}{ Core depth }} \\
\hline CURATORS CODE & $\mathrm{AOM}$ & SRR & $\mathrm{CH} 4 \mathrm{C}$ & URI & GAS & VIR & FISH & DNAI & DNAPCR & DNAS & DNAG & DNAIODP & DNAC & AALEO & LIPH & WRCB & LIPD & $\begin{array}{l}\text { MICT } \\
\end{array}$ & & \\
\hline approx. sample size $(\mathrm{cm})$ & 30 & 10 & 20 & 5 & 6 & 5 & 5 & 5 & 5 & 5 & 5 & 5 & 10 & 5 & 12 & 30 & 5 & 5 & & \\
\hline storage & & $u m b$ & N2, $4^{\circ} \mathrm{C}$, & & $\begin{array}{c}\text { can, } 4^{\circ} \mathrm{C}, \\
\text { poisoned }\end{array}$ & AL-bag, $\mathrm{N}_{2}, 4$ & I ${ }^{\circ} \mathrm{C}$,anox & & & & Poly-b & , $-80^{\circ} \mathrm{C}$ & & & & $4^{\circ} \mathrm{C}$ & \begin{tabular}{|c} 
Poly \\
bag, - \\
$80^{\circ} \mathrm{C}$
\end{tabular} & $4^{\circ} \mathrm{C}$ & & \\
\hline Sample Type & WRC & WRC & WRC & WRC & WRC & WRC & WRC & WRC & WRC & WRC & WRC & WRC & WRC & WRC & WRC & WRC & & WRC & & \\
\hline Core & & & & & & & & & & & & & & & & & & & top & bottom \\
\hline $1 \mathrm{R}$ & - & - & - & - & - & - & - & - & - & - & - & - & - & - & - & - & - & - & 40.00 & 49.20 \\
\hline $2 \mathrm{R}$ & - & - & - & - & - & - & - & - & - & - & - & - & - & - & - & - & - & - & 49.20 & 58.80 \\
\hline $3 R$ & - & - & - & - & - & - & - & - & - & - & - & - & - & - & - & - & - & - & 58.80 & 68.40 \\
\hline $4 \mathrm{R}$ & 1 & - & 1 & - & 1 & - & - & - & - & - & 1 & - & 1 & 1 & 1 & - & - & - & 68.40 & 78.00 \\
\hline $5 R$ & 1 & 1 & 1 & 1 & 1 & - & 1 & 1 & 1 & - & 1 & - & 1 & 1 & 1 & 1 & 1 & - & 78.00 & 87.60 \\
\hline $6 \mathrm{R}$ & 1 & - & 1 & 1 & 1 & - & - & - & - & - & 1 & 1 & 1 & 1 & 1 & - & 1 & - & 87.60 & 97.20 \\
\hline $7 \mathrm{R}$ & 1 & 1 & 1 & 1 & 1 & 1 & 1 & 1 & 1 & 1 & 1 & 1 & 1 & 1 & 1 & 1 & 1 & 1 & 97.20 & 106.90 \\
\hline $8 \mathrm{R}$ & 1 & - & 1 & 1 & 1 & - & - & - & - & - & 1 & 1 & 1 & 1 & 1 & - & 1 & - & 106.90 & 116.60 \\
\hline $9 \mathrm{R}$ & 1 & 1 & 1 & 1 & 1 & - & 1 & 1 & 1 & - & 1 & 1 & 1 & 1 & 1 & 1 & 1 & - & 116.60 & 126.20 \\
\hline $10 \mathrm{R}$ & - & - & - & - & - & - & - & - & - & - & - & - & - & - & - & - & - & - & 126.20 & 133.40 \\
\hline $11 \mathrm{R}$ & 1 & 1 & 1 & 1 & 1 & - & 1 & 1 & 1 & - & 1 & 1 & 1 & 1 & 1 & - & 1 & 1 & 133.40 & 143.10 \\
\hline TOTAL & 7 & 4 & 7 & 6 & 7 & 1 & 4 & 4 & 4 & 1 & 7 & 5 & 7 & 7 & 7 & 3 & 6 & 2 & 89 & Sample \\
\hline
\end{tabular}


Figure F29. A. Total prokaryotic cells (solid circles) vs. depth. Dotted line $=$ global prokaryote profile $\left(\right.$ Parkes et al., 2000) $\left(\log _{10}\right.$ cells $=8.03-0.66 \times$ $\log _{10}$ depth $[\mathrm{m}]$ ), dashed lines $=$ upper and lower prediction limits for this profile, vertical line $=$ detection limit (5.3). B. Percentage of total population involved in cell division vs. depth. C. Geochemical profiles of sulfate (solid squares) and methane (crossed squares). Shading $=$ presence of significant methane concentrations.

A Prokaryote cells $\left(\log _{10}\right.$ numbers $\left./ \mathrm{cm}^{3}\right)$

B

Dividing cells (\%)

C
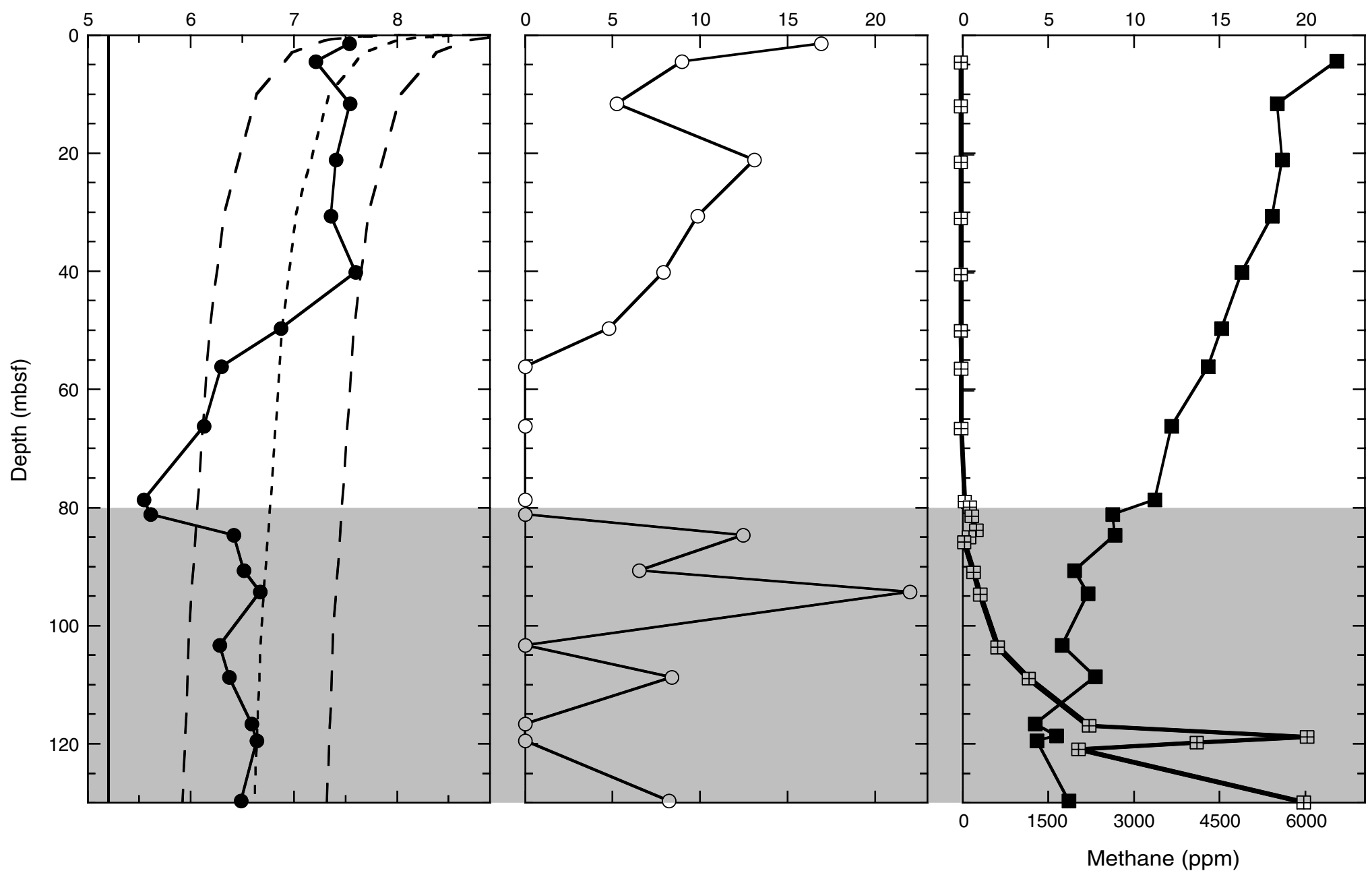
Figure F30. Overview of the spliced depth curves of the different physical properties correlated with local sparker seismics (Line P000660). $P$ wave sensor (PWS) velocity, bulk density, and shear strength are plotted by hole. Blue $=$ Hole U1316A, green $=$ Hole U1316C. GRA $=$ gamma ray attenuation, $\mathrm{PWL}=P$-wave logger, Red line $=$ running average. Logging and physical property units are shown.

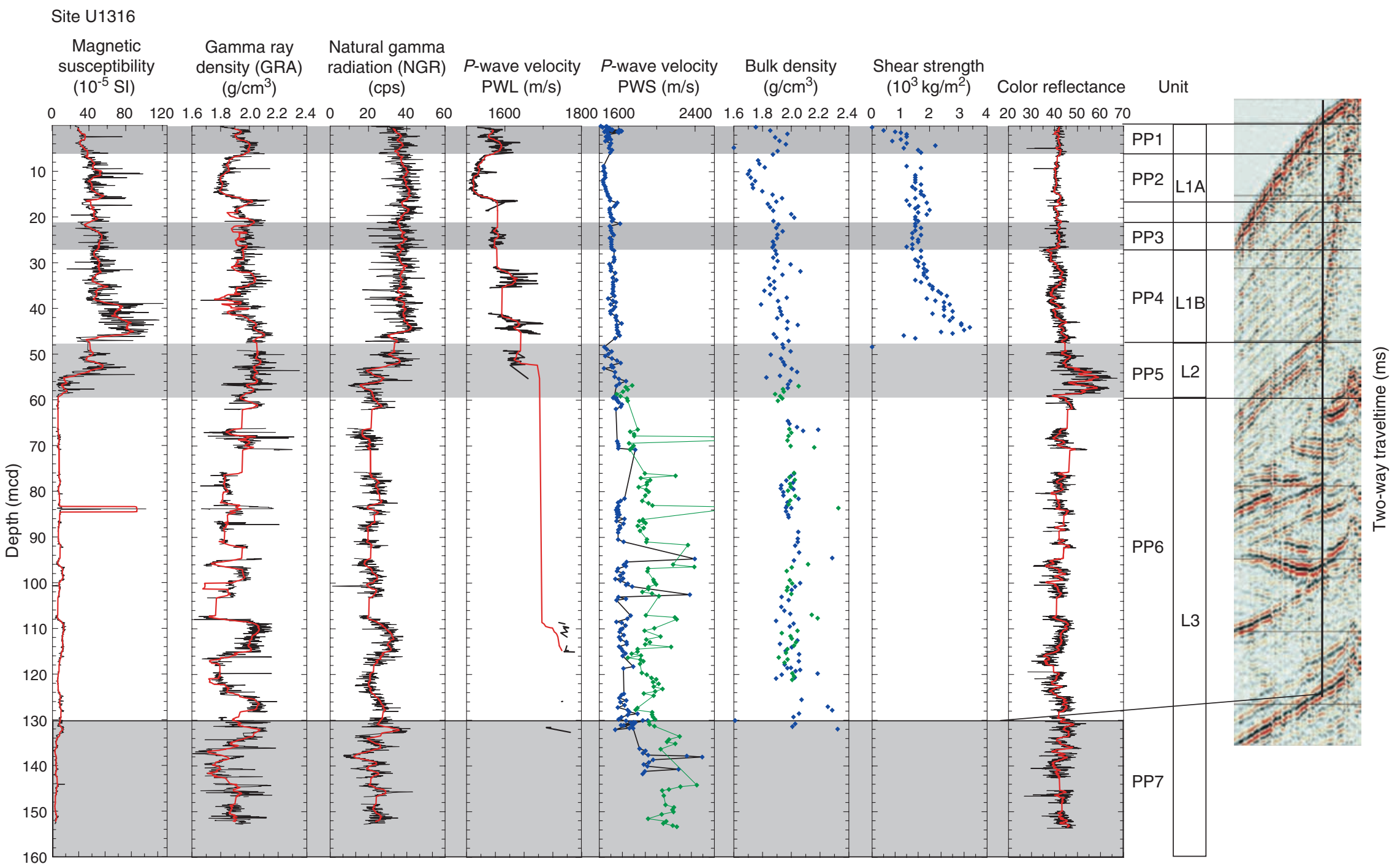


Figure F31. Example temperature data profile collected during deployment of advanced piston corer temperature (APCT) in situ temperature tool.

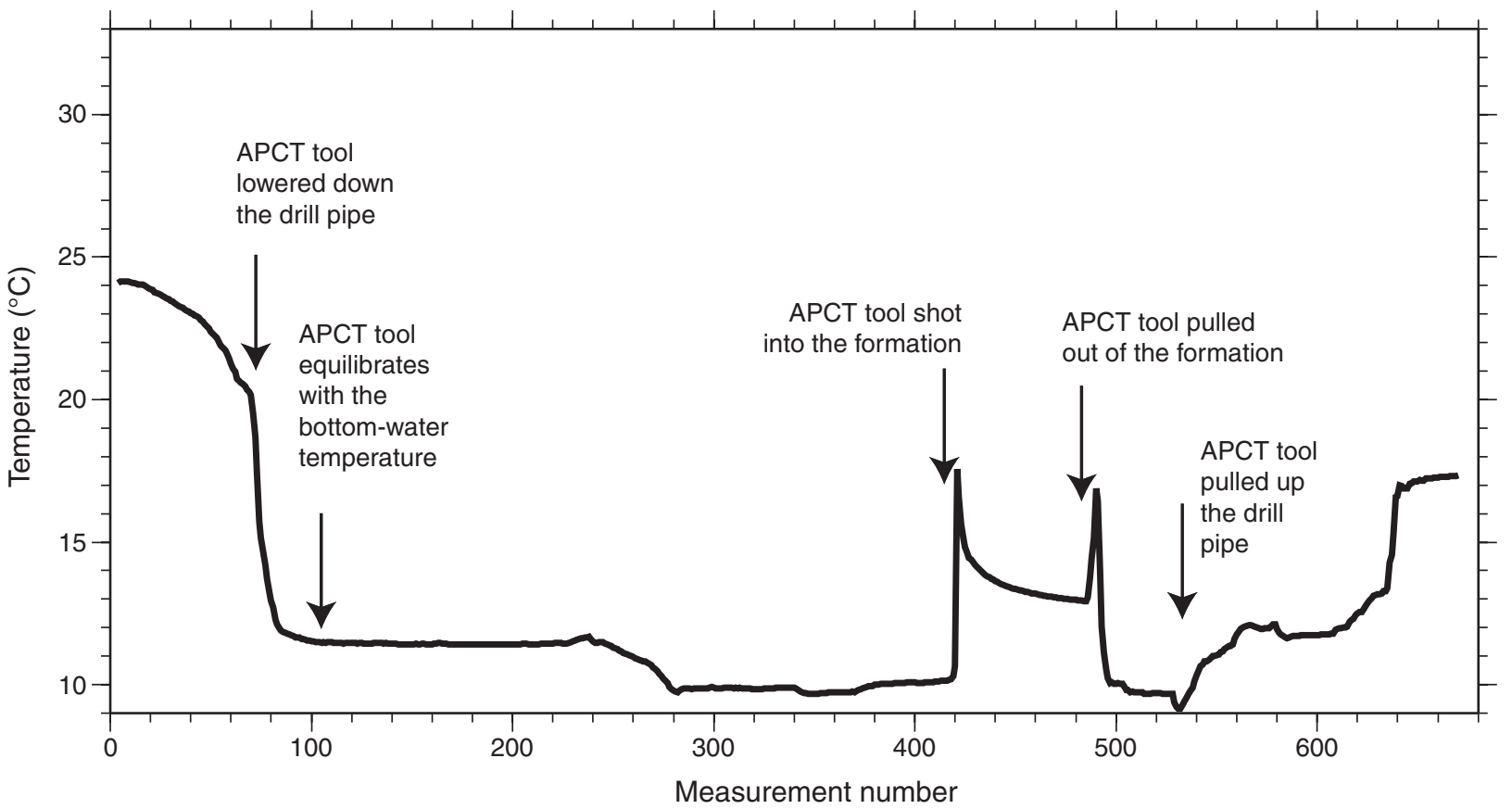


Figure F32. Correlation plots of physical properties. GRA = gamma ray attenuation, NGR = natural gamma radiation, MAD $=$ moisture and density, $\mathrm{PWL}=P$-wave logger, $\mathrm{PWS}=P$-wave sensor

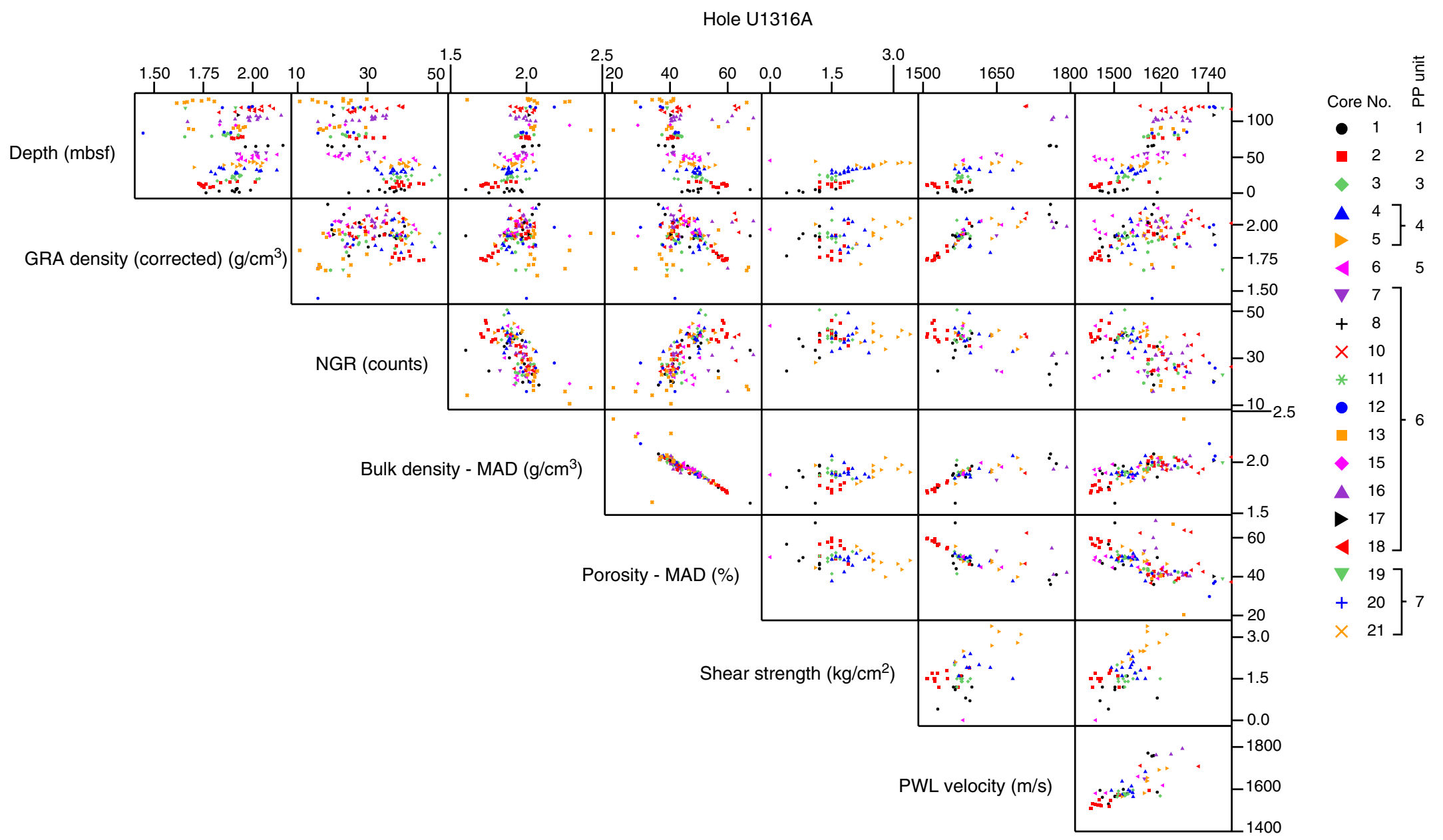

PWS split velocity $(\mathrm{m} / \mathrm{s})$ 
Figure F33. Graphic summary of the logging operations undertaken in Hole U1316C. FMS = Formation MicroScanner.

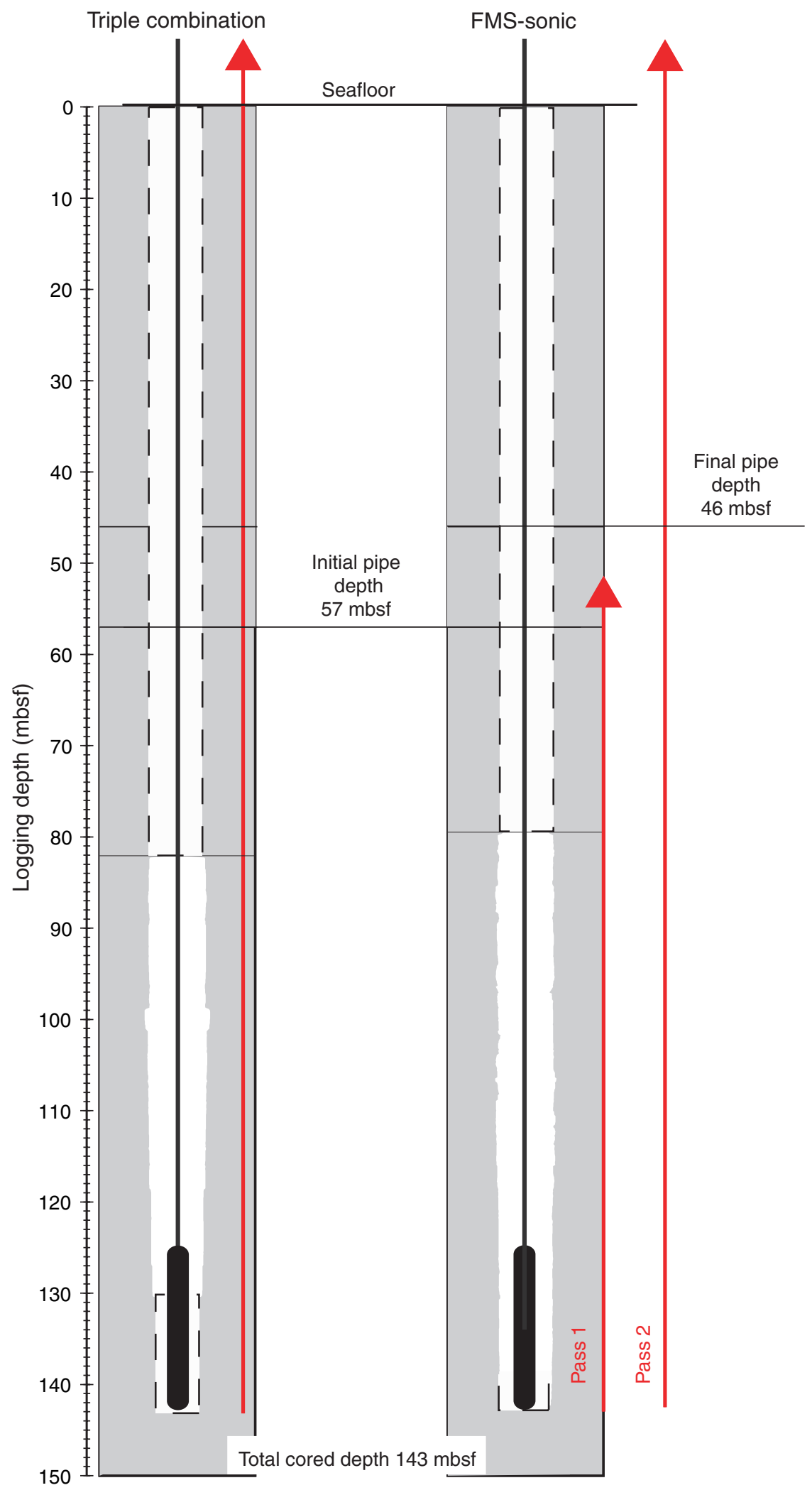


Figure F34. Quality control indicators for the FMS-sonic tool string Pass 1 (green $=$ first pass) and Pass 2 (red $=$ main pass). A. Caliper. B. Vertical tool acceleration $\left(A_{\mathrm{Z}}\right)$. C. Horizontal acceleration $\left(A_{\mathrm{X}}\right)$. D. Horizontal acceleration $\left(A_{\mathrm{y}}\right)$. E. Hole azimuth (HAZI) and orientation (P1AZ) of the FMS-sonic tool string for Pass 1. F. Hole azimuth (HAZI) and orientation (P1AZ) of the FMS-sonic string for Pass 2. G. Angular difference in azimuths $(\Delta)$ between the two FMS passes.

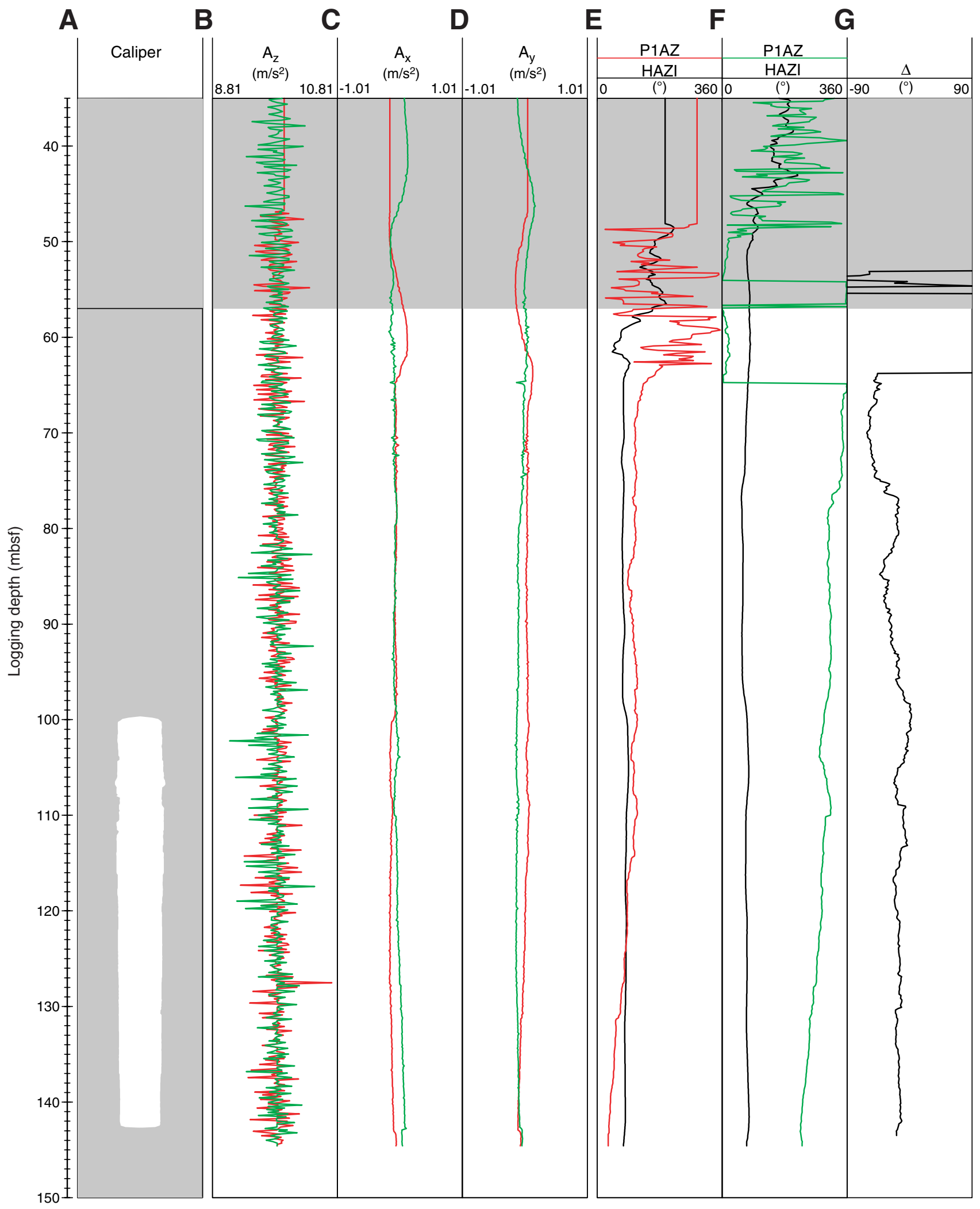


Figure F35. Depth-shifting. A. Total gamma ray log (HSGR) used as reference for depth-shifting. B. Formation MicroScanner (FMS)-sonic tool string gamma ray log (ECGR) in respect to HSGR for Pass 1. C. Formation MicroScanner (FMS)-sonic tool string gamma ray log (ECGR) in respect to HSGR for Pass 2.

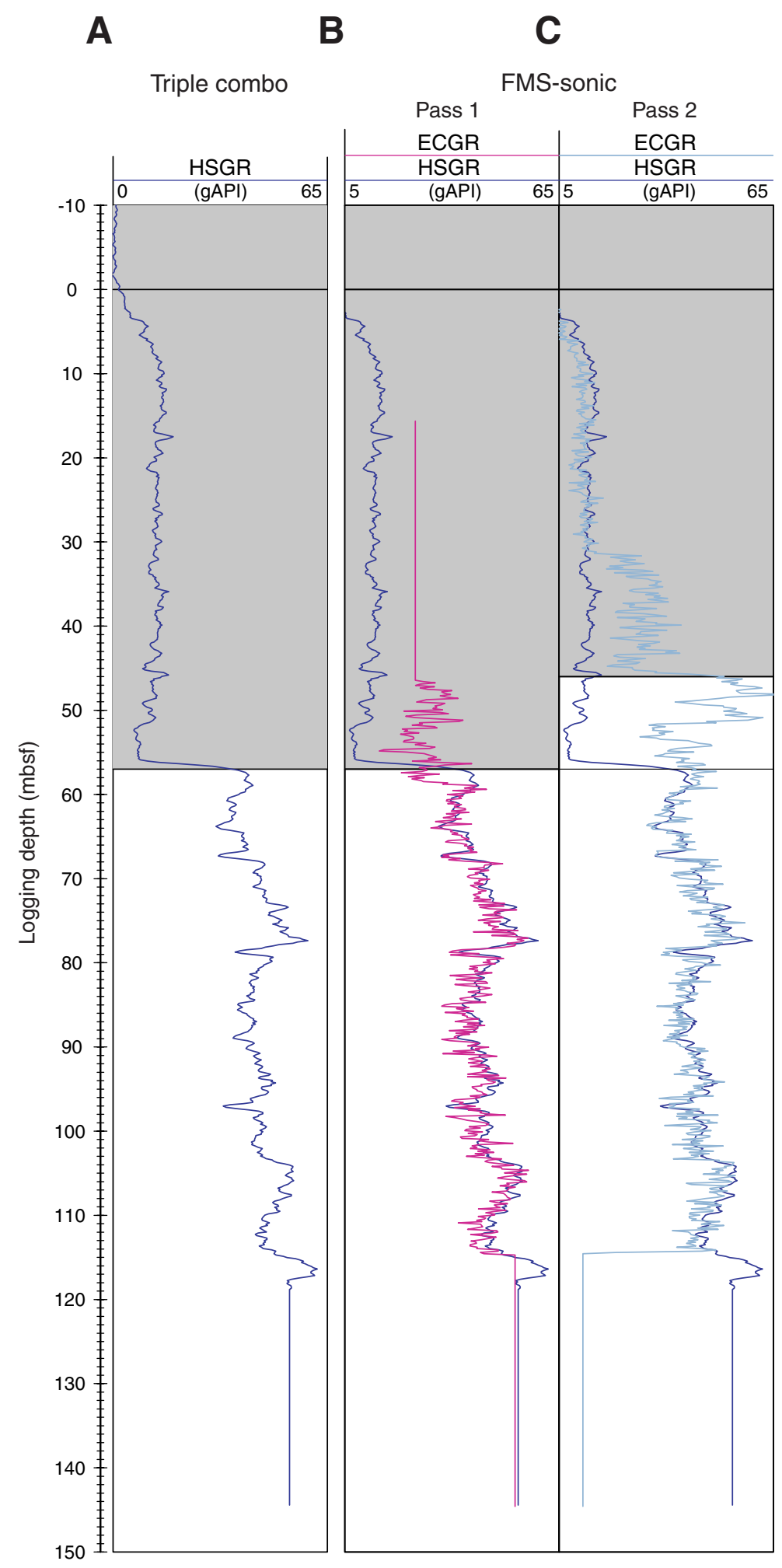


Figure F36. Log stratigraphy. A. Hole shape, total spectral gamma radiation, and potassium content. B. Thorium and uranium. C. Deep, intermediate, and shallow resistivities. D. Porosity and formation density. E. Capture cross-section (SIGF) and photoelectric effect factor (PEF). F. Downhole compressional velocities. G. Logging units.

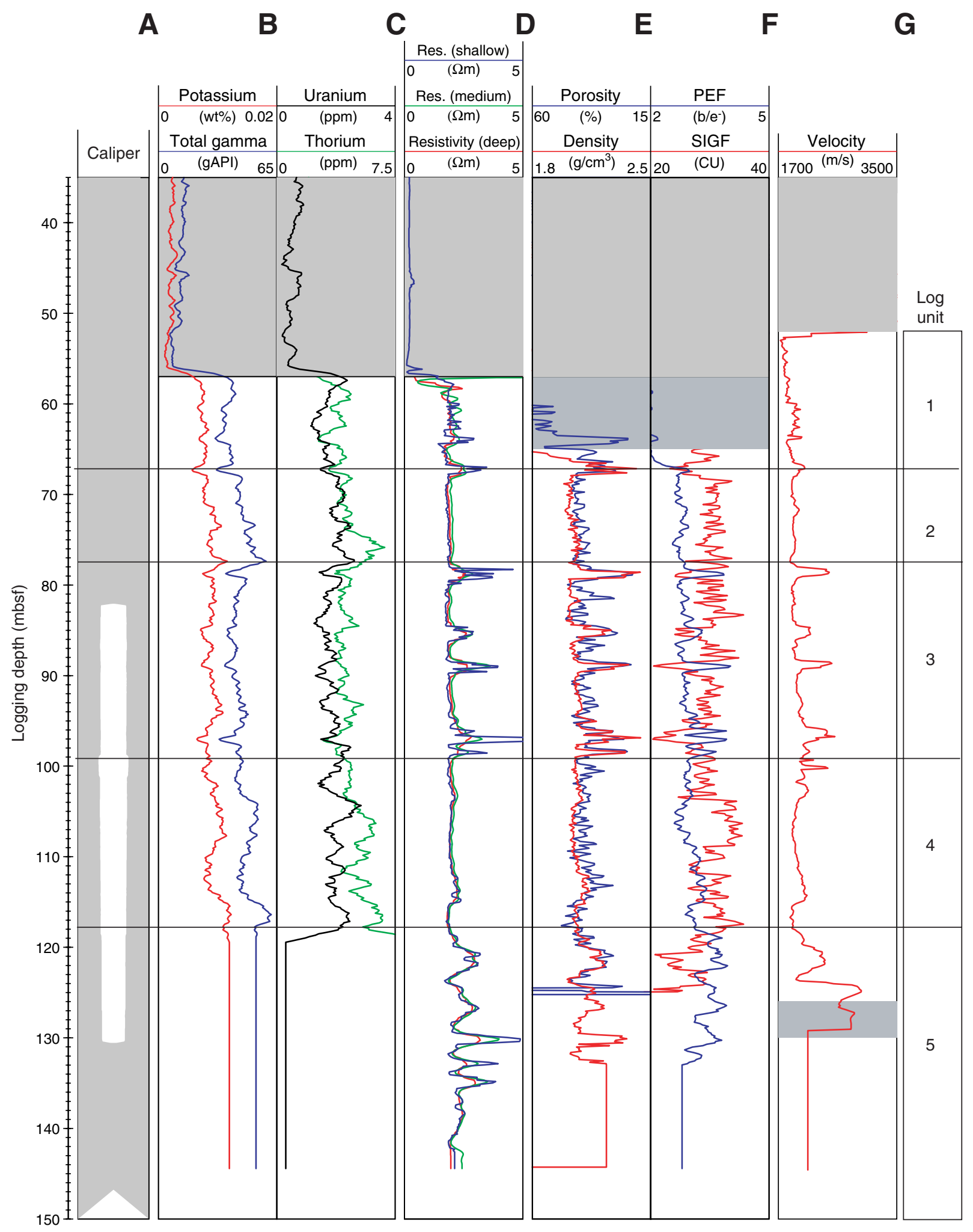


Figure F37. Comparison of equivalent core and log data. Note that in the velocity plots, the range of velocity is similar for all data sets $(1400 \mathrm{~m} / \mathrm{s})$, but absolute values between cores and logs differ by $300 \mathrm{~m} / \mathrm{s}$. NGR = natural gamma radiation, HSGR = total spectral gamma ray, MAD = moisture and density, APLC = porosity, GRA $=$ gamma ray attenuation, $\mathrm{RHOM}=$ bulk density, $\mathrm{PWL}=P$-wave logger, $\mathrm{PWS}=P$-wave sensor.

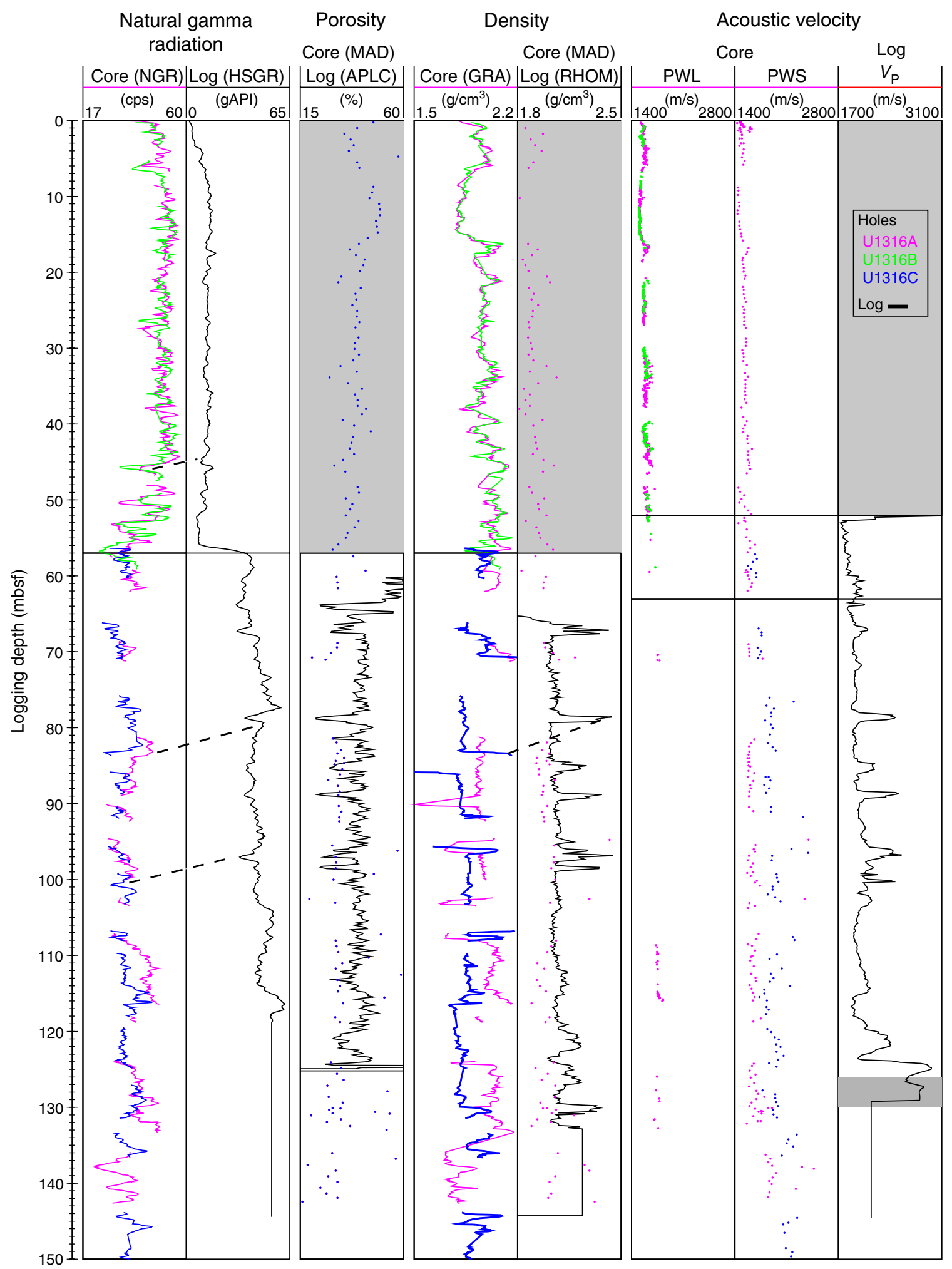


Figure F38. Example of bedding characterization for Formation Microscanner (FMS) images of depth intervals 92-102, 112-122, and 125-135 mbsf. Resistive zones are in light yellow. Conductive zones are in dark brown. Many of the highly resistive layers are characterized by a bedding dipping to the southeast.

A

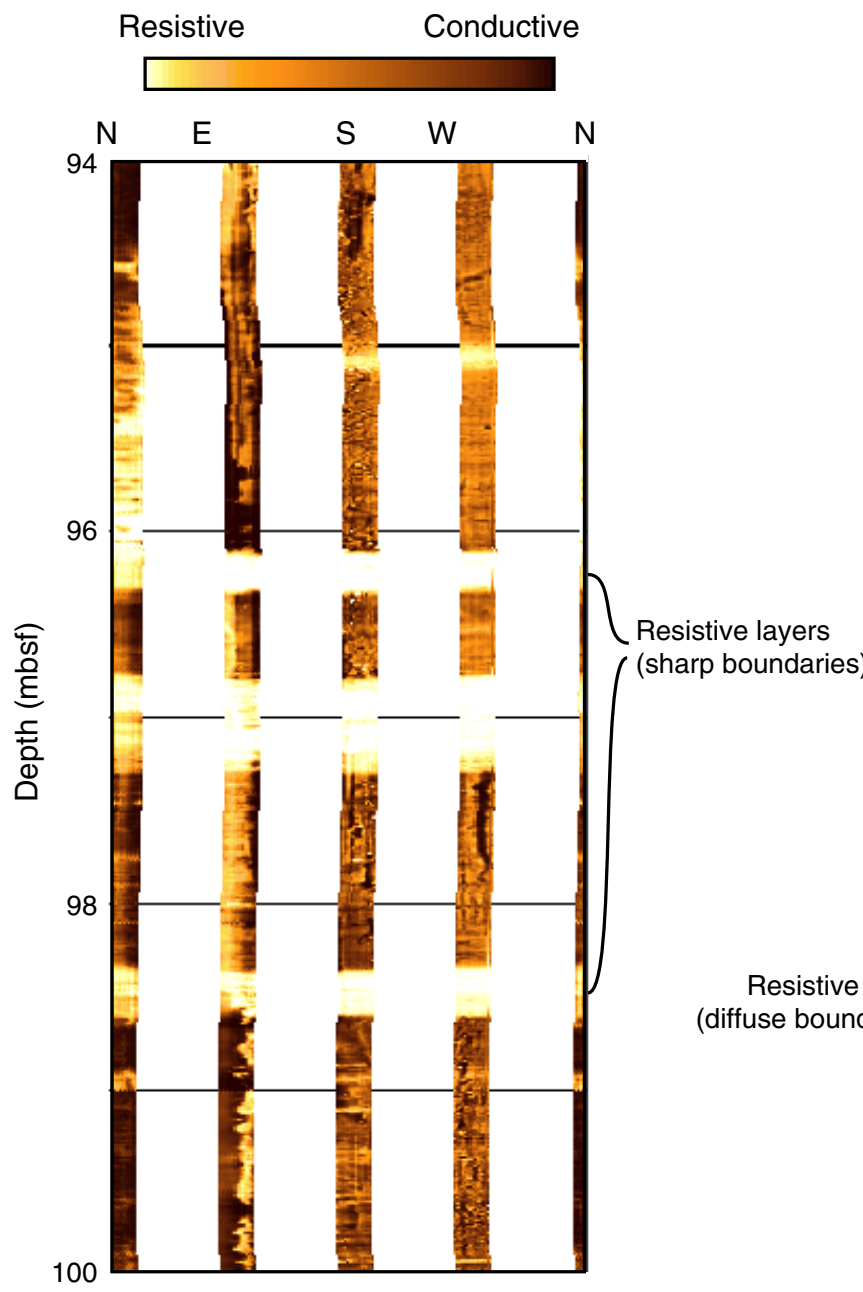

B Logging Unit 5

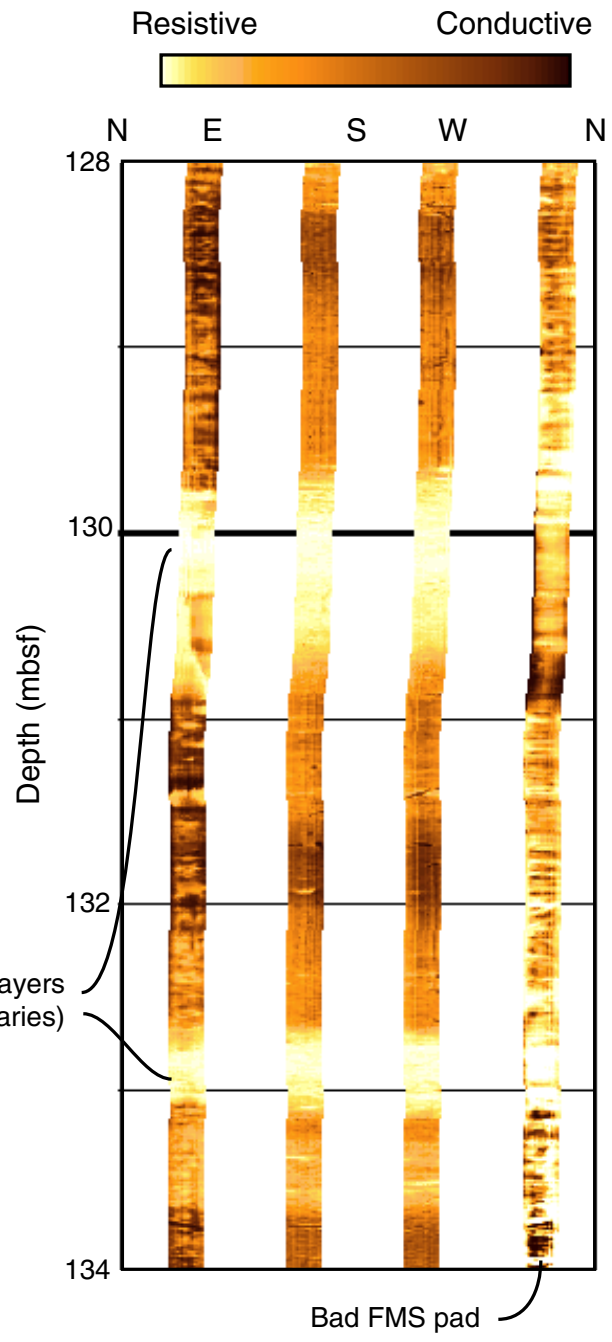


Table T1. Site U1316 coring summary. (Continued on next page.)

\section{Hole U1316A}

Latitude: $51^{\circ} 22.5512^{\prime} \mathrm{N}$

Longitude: $11^{\circ} 43.8030^{\prime} \mathrm{W}$

Seafloor (drill pipe measurement from rig floor; mbrf): 959.20

Distance between rig floor and sea level $(\mathrm{m}): 10.8$

Water depth (drill pipe measurement from sea level; $\mathrm{m}$ ): 948.4

Total depth (from rig floor; mbrf): 1093.2

Total penetration (mbsf): 134.0

\section{Hole U1316B}

Latitude: $51^{\circ} 22.5512^{\prime} \mathrm{N}$

Longitude: $11^{\circ} 43.8030^{\prime} \mathrm{W}$

Seafloor (drill pipe measurement from rig floor; mbrf): 959.0

Distance between rig floor and sea level $(\mathrm{m}): 10.9$

Water depth (drill pipe measurement from sea level; m): 948.1

Total depth (from rig floor; mbrf): 1018.5

Total penetration (mbsf): 59.5

\section{Hole U1316C}

Latitude: $51^{\circ} 22.5512^{\prime} \mathrm{N}$

Longitude: $11^{\circ} 43.8030^{\prime} \mathrm{W}$

Seafloor (drill pipe measurement from rig floor; $\mathrm{mbrf}$ ): 959.0

Distance between rig floor and sea level $(\mathrm{m}): 11.0$

Water depth (drill pipe measurement from sea level; $m$ ): 948.0

Total depth (from rig floor; mbrf): 1102.1

Total penetration (mbsf): 143.1

\begin{tabular}{|c|c|c|c|c|c|c|c|c|}
\hline \multirow[b]{2}{*}{ Core } & \multirow{2}{*}{$\begin{array}{c}\text { Date } \\
(2005)\end{array}$} & \multirow[b]{2}{*}{ Local time } & \multicolumn{2}{|c|}{ Depth (mbsf) } & \multicolumn{2}{|c|}{ Length $(\mathrm{m})$} & \multirow{2}{*}{$\begin{array}{c}\text { Recovery } \\
\text { (\%) }\end{array}$} & \multirow[b]{2}{*}{ Comment } \\
\hline & & & Top & Bottom & Cored & Recovered & & \\
\hline \multicolumn{9}{|c|}{ 307-U1316A- } \\
\hline 1-H & $30 \mathrm{Apr}$ & 1120 & 0.0 & 7.3 & 7.3 & 7.33 & 100.41 & \\
\hline $2-\mathrm{H}$ & $30 \mathrm{Apr}$ & 1220 & 7.3 & 16.8 & 9.5 & 10.04 & 105.68 & \\
\hline $3-\mathrm{H}$ & $30 \mathrm{Apr}$ & 1315 & 16.8 & 26.3 & 9.5 & 10.13 & 106.63 & Start Tensor 1 at $1220 \mathrm{hr}$ \\
\hline $4-\mathrm{H}$ & $30 \mathrm{Apr}$ & 1355 & 26.3 & 35.8 & 9.5 & 9.96 & 104.84 & \\
\hline $5-\mathrm{H}$ & $30 \mathrm{Apr}$ & 1435 & 35.8 & 45.3 & 9.5 & 9.43 & 99.26 & \\
\hline $6-\mathrm{H}$ & $30 \mathrm{Apr}$ & 1535 & 45.3 & 54.8 & 9.5 & 10.02 & 105.47 & \\
\hline $7-\mathrm{H}$ & $30 \mathrm{Apr}$ & 1610 & 54.8 & 64.3 & 9.5 & 3.24 & 34.11 & \\
\hline $8-\mathrm{H}$ & $30 \mathrm{Apr}$ & 1830 & 64.3 & 66.3 & 2.0 & 2.87 & 143.50 & \\
\hline $9-X$ & $30 \mathrm{Apr}$ & 1950 & 66.3 & 75.8 & 9.5 & 0.32 & 3.37 & \\
\hline $10-X$ & $30 \mathrm{Apr}$ & 2105 & 75.8 & 78.3 & 2.5 & 4.35 & 174.00 & \\
\hline $11-x$ & $30 \mathrm{Apr}$ & 2310 & 78.3 & 83.3 & 5.0 & 5.98 & 119.60 & \\
\hline $12-X$ & 1 May & 0140 & 83.3 & 87.8 & 4.5 & 2.81 & 62.44 & \\
\hline $13-X$ & 1 May & 0355 & 87.8 & 93.8 & 6.0 & 5.91 & 98.50 & \\
\hline $14-X$ & 1 May & 0530 & 93.8 & 94.3 & 0.5 & 0.39 & 78.00 & \\
\hline $15-X$ & 1 May & 0715 & 94.3 & 99.0 & 4.7 & 1.66 & 35.32 & \\
\hline $16-X$ & 1 May & 0915 & 99.0 & 108.6 & 9.6 & 9.92 & 103.33 & \\
\hline $17-x$ & 1 May & 1055 & 108.6 & 112.3 & 3.7 & 1.52 & 41.08 & \\
\hline $18-X$ & 1 May & 1230 & 112.3 & 118.3 & 6.0 & 9.92 & 165.33 & \\
\hline $19-X$ & 1 May & 1420 & 118.3 & 118.8 & 0.5 & 1.68 & 336.00 & \\
\hline $20-x$ & 1 May & 1735 & 118.8 & 125.3 & 6.5 & 2.55 & 39.20 & \\
\hline \multirow[t]{2}{*}{$21-x$} & 1 May & 1950 & 125.3 & 134.0 & 8.7 & 7.24 & 83.20 & \\
\hline & & & & Core totals: & 134.0 & 117.27 & 87.51 & \\
\hline \multicolumn{9}{|c|}{ 307-U1316B- } \\
\hline $1-\mathrm{H}$ & 2 May & 0845 & 0.0 & 5.5 & 5.5 & 5.50 & 100.00 & \\
\hline $2-\mathrm{H}$ & 2 May & 0915 & 5.5 & 15.0 & 9.5 & 9.68 & 101.89 & \\
\hline $3-\mathrm{H}$ & 2 May & 0955 & 15.0 & 24.5 & 9.5 & 9.94 & 104.63 & Start Tensor 1 at $0920 \mathrm{hr}$ \\
\hline $4-\mathrm{H}$ & 2 May & 1040 & 24.5 & 34.0 & 9.5 & 9.97 & 104.95 & \\
\hline $5-\mathrm{H}$ & 2 May & 1135 & 34.0 & 43.5 & 9.5 & 9.91 & 104.32 & \\
\hline $6-\mathrm{H}$ & 2 May & 1220 & 43.5 & 53.0 & 9.5 & 10.02 & 105.47 & \\
\hline $7-\mathrm{H}$ & 2 May & 1315 & 53.0 & 59.3 & 6.3 & 6.33 & 100.48 & \\
\hline \multirow[t]{2}{*}{$8-\mathrm{H}$} & 2 May & 1400 & 59.3 & 59.5 & 0.2 & 0.18 & 90.00 & \\
\hline & & & & Core totals: & 59.5 & 61.53 & 103.41 & \\
\hline
\end{tabular}


Table T1 (continued).

\begin{tabular}{|c|c|c|c|c|c|c|c|c|}
\hline \multirow[b]{2}{*}{ Core } & \multirow{2}{*}{$\begin{array}{c}\text { Date } \\
(2005)\end{array}$} & \multirow[b]{2}{*}{ Local time } & \multicolumn{2}{|c|}{ Depth (mbsf) } & \multicolumn{2}{|c|}{ Length $(\mathrm{m})$} & \multirow{2}{*}{$\begin{array}{l}\text { Recovery } \\
\text { (\%) }\end{array}$} & \multirow[b]{2}{*}{ Comment } \\
\hline & & & Top & Bottom & Cored & Recovered & & \\
\hline \multicolumn{9}{|c|}{ 307-U1316C- } \\
\hline \multicolumn{9}{|c|}{$\star \star \star \star \star \star$ Drilled from 0.0 to $40.0 \mathrm{mbsf}^{* \star \star \star *}$} \\
\hline $1-R$ & 7 May & 0930 & 40.0 & 49.2 & 9.2 & 0.25 & 2.72 & \\
\hline $2-\mathrm{R}$ & 7 May & 1030 & 49.2 & 58.8 & 9.6 & 4.36 & 45.42 & \\
\hline $3-R$ & 7 May & 1150 & 58.8 & 68.4 & 9.6 & 5.10 & 53.12 & \\
\hline $4-\mathrm{R}$ & 7 May & 1325 & 68.4 & 78.0 & 9.6 & 8.04 & 83.75 & \\
\hline $5-\mathrm{R}$ & 7 May & 1455 & 78.0 & 87.6 & 9.6 & 6.24 & 65.00 & \\
\hline $6-R$ & 7 May & 1600 & 87.6 & 97.2 & 9.6 & 7.77 & 80.94 & \\
\hline $7-R$ & 7 May & 1720 & 97.2 & 106.9 & 9.7 & 10.00 & 103.09 & \\
\hline $8-R$ & 7 May & 1820 & 106.9 & 116.6 & 9.7 & 8.50 & 87.63 & \\
\hline $9-R$ & 7 May & 2000 & 116.6 & 126.2 & 9.6 & 9.93 & 103.44 & \\
\hline $10-R$ & 7 May & 2215 & 126.2 & 133.4 & 7.2 & 0.00 & 0.00 & \\
\hline \multirow[t]{2}{*}{$11-R$} & 8 May & 0010 & 133.4 & 143.1 & 9.7 & 9.96 & 102.68 & \\
\hline & & & & Core totals: & 103.1 & 70.15 & 68.04 & \\
\hline
\end{tabular}

Table T2. Calcareous nannofossil biostratigraphic data used for splice correlation, Hole U1316A.

\begin{tabular}{lc}
\hline \multicolumn{1}{c}{ Datum } & Age (Ma) \\
\hline FAD Emiliania huxleyi & 0.26 \\
LAD Pseudoemiliania lacunosa & 0.46 \\
LAD Calcidiscus macintyrei & 1.59 \\
LAD Sphenolithus heteromorphus & 13.60 \\
LAD Helicosphaera ampliaperta & 15.60 \\
FAD Sphenolithus heteromorphus & 18.30 \\
FAD Helicosphaera ampliaperta & 23.20 \\
LAD Reticulofenestra gartnerii 5-7 $\mu \mathrm{m}$ & \\
FAD Reticulofenestra gartnerii 5-7 $\mu \mathrm{m}$ & early middle Miocene \\
LAD Discoaster deflandrei & \\
\hline
\end{tabular}

Note: $F A D=$ first appearance datum, LAD = last appearance datum.

Table T3. Nannofossil age assignments, Hole U1316C.

\begin{tabular}{lrl}
\hline $\begin{array}{c}\text { Core, section, } \\
\text { interval }(\mathrm{cm})\end{array}$ & $\begin{array}{r}\text { Depth } \\
(\mathrm{mbsf})\end{array}$ & \multicolumn{1}{c}{ Nannofossil age } \\
\hline 307-U1316C- & & - \\
1R-CC & 40.0 & \\
2R-CC & 53.3 & \\
3R-CC & 63.7 & early middle Miocene (13.6-15.6 Ma) \\
4R-4, 15-16 & 73.4 & \\
4R-4, 105-106 & 74.0 & \\
5R-3, 26-27 & 81.3 & \\
5R-3, 106-107 & 82.1 & \\
6R-2, 70-71 & 89.8 & late early Miocene (15.6-18.2 Ma) \\
7R-2, 37-38 & 99.1 & \\
7R-3, 47-48 & 100.7 & \\
8R-2, 95-96 & 109.4 & \\
\hline
\end{tabular}

Note: $-=$ poor recovery. 
Table T4. Planktonic foraminifer biostratigraphic data used for splice correlation, Hole U1316A.

\begin{tabular}{llrc}
\hline \multicolumn{1}{c}{ Datum } & Core, section & $\begin{array}{c}\text { Depth } \\
(\mathrm{mbsf})\end{array}$ & $\begin{array}{c}\text { Age } \\
(\mathrm{Ma})\end{array}$ \\
\hline & $307-\mathrm{U} 1316 \mathrm{~A}-$ & & \\
FAD Globorotalia truncatulinoides & $6 \mathrm{H}-\mathrm{CC}$ & 54.9 & 1.96 \\
FAD Globorotalia inflata & $6 \mathrm{H}-\mathrm{CC}$ & 54.9 & 3.2 \\
LAD Praeorbulina sicanus & 7H-CC & 57.8 & 14.8 \\
FAD Praeorbulina sicanus & 21H-CC & 132.2 & 16.4 \\
\hline
\end{tabular}

Note: $F A D=$ first appearance datum, LAD = last appearance datum. 
Table T5. Interstitial water data, Holes U1316A, U1316B, and U1316C.

\begin{tabular}{|c|c|c|c|c|c|c|c|c|c|c|c|c|c|c|c|c|c|}
\hline \multirow{3}{*}{$\begin{array}{l}\text { Core, section, } \\
\text { interval }(\mathrm{cm})\end{array}$} & \multirow{3}{*}{$\begin{array}{l}\text { Depth } \\
\text { (mbsf) }\end{array}$} & \multirow[b]{3}{*}{$\mathrm{pH}$} & \multirow{3}{*}{$\begin{array}{l}\text { Alkalinity } \\
(\mathrm{mM})\end{array}$} & \multirow{2}{*}{\multicolumn{7}{|c|}{ Trace elements $(\mu \mathrm{m})$}} & \multirow{2}{*}{\multicolumn{2}{|c|}{ Cations (mM) }} & \multirow{3}{*}{$\begin{array}{c}\text { DIC } \\
(\mathrm{mM})\end{array}$} & \multirow{3}{*}{$\underset{(\mathrm{mM})}{\mathrm{SO}_{4}}$} & \multicolumn{2}{|c|}{ Chlorinity } & \multirow{3}{*}{$\begin{array}{l}\mathrm{NH}_{4}^{+} \\
(\mu \mathrm{M})\end{array}$} \\
\hline & & & & & & & & & & & & & & & IC & titr. & \\
\hline & & & & B & $\mathrm{Ba}$ & $\mathrm{Fe}$ & $\mathrm{Li}$ & $\mathrm{Mn}$ & $\mathrm{Si}$ & $\mathrm{Sr}$ & $\mathrm{Ca}$ & $\mathrm{Mg}$ & & & $(\mathrm{mM})$ & $(\mathrm{mM})$ & \\
\hline \multicolumn{18}{|l|}{ 307-U1316A- } \\
\hline $1 \mathrm{H}-3,145-150$ & 4.45 & 7.51 & 7.24 & 536 & 1.51 & 37.2 & 32.0 & 6.80 & 171 & 92.4 & 8.73 & 50.5 & 8.21 & 21.9 & 578 & 565 & 594 \\
\hline $2 \mathrm{H}-3,140-150$ & 11.70 & 7.33 & 5.99 & 558 & 0.771 & 62.8 & 32.0 & 3.86 & 242 & 94.2 & 8.06 & 49.4 & 7.08 & 18.4 & 567 & 570 & 677 \\
\hline $3 \mathrm{H}-3,140-150$ & 21.20 & 7.57 & 5.25 & 548 & 0.860 & 26.1 & 32.5 & 2.82 & 158 & 130 & 8.28 & 46.0 & 6.06 & 18.7 & 574 & ND & ND \\
\hline $4 \mathrm{H}-3,140-150$ & 30.70 & 7.43 & 6.07 & 585 & 1.05 & 12.2 & 39.7 & 4.25 & 231 & 176 & 9.58 & 51.1 & 7.27 & 18.1 & 573 & 575 & 670 \\
\hline $5 \mathrm{H}-3,140-150$ & 40.20 & 7.44 & 6.45 & 814 & 1.14 & 20.7 & 53.6 & 3.36 & 263 & 248 & 8.16 & 44.0 & 7.72 & 16.3 & 572 & 573 & 734 \\
\hline $6 \mathrm{H}-3,140-150$ & 49.70 & 7.44 & 7.03 & 856 & 0.476 & 25.3 & 71.4 & 2.18 & 308 & 321 & 8.75 & 44.7 & 8.25 & 15.1 & 585 & 574 & 838 \\
\hline $7 \mathrm{H}-1,140-150$ & 56.20 & 7.55 & 8.14 & 733 & 0.753 & 12.0 & 77.0 & 1.50 & 779 & 324 & 9.83 & 45.7 & 9.52 & 14.4 & 584 & 570 & 918 \\
\hline $8 \mathrm{H}-2,140-150$ & 66.29 & 7.34 & 9.20 & 1070 & 0.718 & 3.88 & 114 & 1.38 & 919 & 470 & 10.2 & 43.0 & 11.3 & 12.2 & 575 & 568 & 988 \\
\hline $10 X-2,140-150$ & 78.70 & 7.33 & 13.7 & 1140 & 1.51 & 5.59 & 147 & 2.91 & 1080 & 524 & 11.6 & 43.5 & 16.7 & 11.3 & 577 & 573 & ND \\
\hline $11 X-2,140-150$ & 81.20 & 7.29 & 11.4 & 1190 & 1.78 & 7.52 & 176 & 1.45 & 1060 & 507 & 11.0 & 40.6 & 13.9 & 8.79 & 592 & 572 & ND \\
\hline $12 X-1,140-150$ & 84.70 & 7.32 & 11.8 & 1380 & 1.17 & 4.23 & 163 & 1.54 & 1020 & 622 & 10.9 & 42.4 & 12.9 & 8.92 & 575 & 573 & ND \\
\hline $13 X-2,140-150$ & 90.70 & 7.42 & 11.6 & 1330 & 1.05 & 7.75 & 175 & 1.34 & 850 & 620 & 10.2 & 38.3 & 13.4 & 6.54 & 579 & 574 & ND \\
\hline $15 X-1,25-35$ & 94.55 & 7.60 & 10.6 & 1530 & 4.58 & 1.94 & 193 & 1.44 & 840 & 765 & 9.7 & 40.6 & ND & 7.32 & 577 & 579 & ND \\
\hline $16 X-3,140-150$ & 103.40 & 7.27 & 13.2 & 1720 & 2.43 & 23.1 & 228 & 1.47 & 1180 & 905 & 10.7 & 39.9 & 14.9 & 5.80 & 581 & 578 & ND \\
\hline $17 X-1,7-17$ & 108.67 & 7.42 & 12.3 & 1940 & 3.37 & 17.5 & 231 & 1.43 & 1040 & 1010 & 11.3 & 40.2 & 12.1 & 7.76 & 576 & 574 & ND \\
\hline $18 X-3,140-150$ & 116.70 & 7.19 & 11.9 & 2060 & 7.70 & 28.5 & 281 & 1.80 & 1150 & 865 & 13.4 & 37.2 & 14.4 & 4.24 & 581 & 578 & ND \\
\hline $19 X-1,39-49$ & 118.69 & 7.37 & 10.8 & 2230 & 1.97 & 10.6 & 273 & 1.33 & 910 & 1120 & 11.1 & 38.6 & 12.7 & 5.49 & 563 & 579 & ND \\
\hline $20 \mathrm{X}-1,75-85$ & 119.55 & 7.21 & 11.3 & 3130 & 4.73 & 13.1 & 354 & 1.43 & 1200 & 894 & 16.7 & 30.9 & 14.0 & 4.35 & 565 & 583 & ND \\
\hline $21 X-3,140-150$ & 129.70 & 7.35 & 9.86 & 1470 & 3.10 & 1.28 & 172 & 1.14 & 434 & 676 & 12.1 & 36.1 & 12.1 & 6.23 & 565 & 583 & ND \\
\hline \multicolumn{18}{|l|}{ 307-U1316B- } \\
\hline $1 \mathrm{H}-1,140-150$ & 1.40 & 7.42 & 4.90 & 475 & 0.526 & 99.5 & 32.2 & 6.98 & 234 & 89.8 & 10.6 & 51.8 & 4.66 & 25.2 & 571 & 573 & 242 \\
\hline $1 \mathrm{H}-3,190-200$ & 4.90 & 7.59 & 7.36 & 479 & 0.754 & 54.7 & 32.8 & 5.51 & 204 & 96.4 & 9.16 & 50.3 & 6.89 & 20.9 & 574 & 577 & 605 \\
\hline $2 \mathrm{H}-1,140-150$ & 6.90 & 7.47 & 7.23 & 524 & 0.616 & 49.9 & 34.1 & 2.63 & 213 & 95.0 & 8.49 & 49.9 & 6.75 & 19.7 & 572 & 570 & 660 \\
\hline $2 \mathrm{H}-3,190-200$ & 10.40 & 7.45 & 6.39 & 542 & 0.570 & 75.6 & 34.8 & 2.35 & 314 & 103 & 8.46 & 49.3 & 6.02 & 18.8 & 567 & ND & 625 \\
\hline $3 \mathrm{H}-1,140-150$ & 16.40 & 7.50 & 5.64 & 528 & 0.553 & 29.4 & 34.2 & 2.85 & 172 & 115 & 8.47 & 47.5 & 5.12 & 18.3 & 570 & 577 & 701 \\
\hline $3 \mathrm{H}-3,190-200$ & 19.90 & 7.50 & 5.40 & 512 & 0.556 & 30.1 & 35.4 & 2.99 & 221 & 127 & 8.96 & 46.8 & 1.81 & 18.5 & 572 & 573 & 658 \\
\hline $4 \mathrm{H}-1,140-150$ & 25.90 & 7.46 & 5.49 & 568 & 0.471 & 67.2 & 36.6 & 2.08 & 192 & 152 & 10.1 & 46.6 & 5.08 & 19.1 & 577 & 579 & 651 \\
\hline $4 \mathrm{H}-3,190-200$ & 29.40 & 7.61 & 5.92 & 573 & 0.582 & 20.5 & 39.1 & 2.31 & 230 & 172 & 11.6 & 48.6 & 5.23 & 19.4 & 587 & 574 & 596 \\
\hline $5 \mathrm{H}-1,140-150$ & 35.40 & 7.47 & 6.53 & 631 & 0.651 & 13.8 & 49.1 & 2.67 & 321 & 203 & 8.94 & 48.1 & 5.83 & 18.8 & 575 & 578 & 605 \\
\hline $5 \mathrm{H}-3,190-200$ & 38.90 & 7.44 & 6.51 & 614 & 0.582 & 45.9 & 48.6 & 2.44 & 268 & 224 & 8.48 & 45.9 & 6.10 & 18.1 & 573 & 575 & 767 \\
\hline $6 \mathrm{H}-1,140-150$ & 44.90 & 7.49 & 6.44 & 617 & 0.540 & 26.0 & 57.6 & 1.23 & 190 & 259 & 10.7 & 45.0 & 6.24 & 17.2 & 584 & 576 & ND \\
\hline $6 \mathrm{H}-3,190-200$ & 48.40 & 7.69 & 6.86 & 706 & 0.626 & 75.8 & 65.8 & 1.36 & 297 & 290 & 8.85 & 45.4 & 5.64 & 16.8 & 569 & ND & 782 \\
\hline \multicolumn{18}{|l|}{ 307-U1316C- } \\
\hline $4 \mathrm{R}-4,135-150$ & 74.25 & 7.64 & 9.80 & 1110 & 0.82 & 0 & 143 & 0.39 & 799 & 536 & 10.0 & 41.9 & 10.3 & 11.9 & 578 & 578 & 1145 \\
\hline $5 R-3,135-150$ & 82.35 & 7.42 & 11.6 & 1320 & 1.08 & 0 & 165 & 0 & 819 & 622 & 10.2 & 41.5 & 11.8 & 9.93 & 577 & 577 & 1238 \\
\hline $6 \mathrm{R}-3,74-94$ & 90.90 & 7.39 & 12.4 & 1490 & 0.85 & 0 & 189 & 0 & 818 & 707 & 10.1 & 39.3 & ND & 7.63 & 578 & 578 & 1504 \\
\hline $7 \mathrm{R}-2,130-150$ & 100.00 & 7.41 & 12.7 & 1650 & 1.13 & 2.45 & 216 & 0 & 801 & 801 & 9.94 & 38.4 & 12.5 & ND & 587 & 587 & 1566 \\
\hline $8 \mathrm{R}-2,130-150$ & 109.70 & 7.26 & 11.4 & 1820 & 7.67 & 0 & 240 & 0.86 & 852 & 891 & 10.8 & 38.5 & 12.1 & 6.46 & 581 & 581 & 1634 \\
\hline $9 R-4,130-150$ & 122.40 & ND & ND & ND & ND & ND & ND & ND & ND & ND & ND & ND & ND & 7.06 & 581 & 581 & 1712 \\
\hline $11 \mathrm{R}-3,140-150$ & 137.80 & ND & ND & 1930 & 1.45 & 0 & 331 & 0 & 655 & 1090 & 12.2 & 34.7 & ND & 7.06 & 571 & 571 & 1915 \\
\hline
\end{tabular}

Notes: DIC = dissolved inorganic carbon, IC = ion chromatography, titr. = titration. ND = not determined. 
Table T6. Headspace gas, Holes U1316A and U1316B.

\begin{tabular}{|c|c|c|c|c|c|c|c|c|}
\hline Core, section & $\begin{array}{l}\text { Depth } \\
\text { (mbsf) }\end{array}$ & $\begin{array}{l}\text { Safety } \mathrm{CH}_{4} \\
\quad(\mathrm{ppm})\end{array}$ & $\begin{array}{l}\text { Safety } \mathrm{C}_{2} \mathrm{H}_{6} \\
\quad(\mathrm{ppm})\end{array}$ & $\begin{array}{c}\text { Dissolved } \mathrm{CH}_{4} \\
\quad(\mu \mathrm{M})\end{array}$ & $\begin{array}{c}\text { Adsorbed } \mathrm{CH}_{4} \\
(\mu \mathrm{mol} / \mathrm{g})\end{array}$ & $\begin{array}{c}\text { Dissolved } \mathrm{C}_{2} \mathrm{H}_{6} \\
(\mu \mathrm{M})\end{array}$ & $\begin{array}{l}\text { Adsorbed } \mathrm{C}_{2} \mathrm{H}_{6} \\
(\mu \mathrm{mol} / \mathrm{g})\end{array}$ & $\begin{array}{l}\text { Adsorbed propane } \\
(\mu \mathrm{mol} / \mathrm{g})\end{array}$ \\
\hline \multicolumn{9}{|l|}{ 307-U1316A- } \\
\hline $1 \mathrm{H}-3$ & 4.4 & 1.7 & BDL & BDL & $4.1 \mathrm{E}-04$ & BDL & BDL & BDL \\
\hline $2 \mathrm{H}-4$ & 11.8 & 1.8 & BDL & BDL & $4.2 \mathrm{E}-04$ & BDL & BDL & BDL \\
\hline $3 \mathrm{H}-4$ & 21.3 & 1.7 & BDL & BDL & $7.3 \mathrm{E}-04$ & $\mathrm{BDL}$ & BDL & BDL \\
\hline $4 \mathrm{H}-4$ & 30.8 & 2.0 & BDL & BDL & $3.0 \mathrm{E}-04$ & $\mathrm{BDL}$ & BDL & BDL \\
\hline $5 \mathrm{H}-4$ & 40.3 & 1.8 & BDL & BDL & $3.3 \mathrm{E}-04$ & BDL & BDL & BDL \\
\hline $6 \mathrm{H}-4$ & 49.8 & 1.9 & BDL & BDL & $2.5 \mathrm{E}-04$ & BDL & BDL & BDL \\
\hline 7H-2 & 56.3 & 3.8 & BDL & 0.063 & $8.0 \mathrm{E}-03$ & BDL & $1.8 \mathrm{E}-04$ & BDL \\
\hline $8 \mathrm{H}-3$ & 66.39 & 5.8 & BDL & 0.081 & $2.9 \mathrm{E}-03$ & BDL & $1.1 \mathrm{E}-04$ & BDL \\
\hline $9 X-3$ & 78.8 & 69 & 2.6 & ND & ND & ND & ND & ND \\
\hline $10 X-3$ & 79.73 & 157 & 6.0 & 51.5 & $1.22 \mathrm{E}-02$ & 2.0 & $1.9 \mathrm{E}-04$ & BDL \\
\hline $11 X-3$ & 81.3 & 188 & 6.2 & 45.6 & $2.81 \mathrm{E}-02$ & 1.5 & $9.9 \mathrm{E}-04$ & BDL \\
\hline $11 X-4$ & 83.61 & 269 & 9.5 & 62.9 & ND & 2.2 & ND & ND \\
\hline $12 X-2$ & 84.8 & 143 & 4.9 & 52.8 & $1.34 \mathrm{E}-02$ & 1.8 & $3.4 \mathrm{E}-04$ & BDL \\
\hline $12 \mathrm{X}-\mathrm{CC}$ & 85.68 & 60.0 & 18.2 & 16.7 & ND & 5.2 & ND & ND \\
\hline $13 X-3$ & 90.8 & 222 & 7.8 & 97.7 & 1.37E-02 & 3.5 & $3.6 \mathrm{E}-04$ & BDL \\
\hline $15 X-1$ & 94.54 & 335 & 14.4 & 67.2 & $3.02 \mathrm{E}-02$ & 2.9 & $3.3 \mathrm{E}-04$ & $\mathrm{BDL}$ \\
\hline $16 X-4$ & 103.5 & 637 & 10.0 & 230 & $9.89 \mathrm{E}-02$ & 3.6 & $1.8 \mathrm{E}-03$ & $4.0 \mathrm{E}-04$ \\
\hline $17 X-1$ & 108.77 & 1180 & 11.1 & 574 & $4.55 \mathrm{E}-03$ & 5.4 & $4.5 \mathrm{E}-04$ & BDL \\
\hline $18 X-4$ & 116.8 & 2230 & 14.1 & 718 & $9.25 \mathrm{E}-02$ & 4.6 & $9.1 \mathrm{E}-04$ & $1.7 \mathrm{E}-04$ \\
\hline 19X-1 & 118.68 & 6020 & 31.8 & 1730 & ND & 9.1 & ND & ND \\
\hline $20 X-2$ & 119.65 & 4100 & 20.4 & 907 & $1.88 \mathrm{E}-01$ & 4.5 & $1.5 \mathrm{E}-03$ & $3.4 \mathrm{E}-04$ \\
\hline $20 X-2$ & 120.83 & 2050 & 18.8 & 808 & ND & 7.4 & ND & ND \\
\hline $21 X-4$ & 129.8 & 5950 & 28.7 & 2010 & ND & 9.7 & ND & $\mathrm{BDL}$ \\
\hline \multicolumn{9}{|l|}{ 307-U1316B- } \\
\hline $1 \mathrm{H}-4$ & 5 & ND & ND & ND & $4.81 \mathrm{E}-03$ & ND & BDL & BDL \\
\hline $2 \mathrm{H}-4$ & 10.5 & ND & ND & ND & $1.66 \mathrm{E}-03$ & ND & BDL & BDL \\
\hline $3 \mathrm{H}-4$ & 20 & ND & ND & ND & $1.59 \mathrm{E}-03$ & ND & BDL & $\mathrm{BDL}$ \\
\hline $4 \mathrm{H}-4$ & 29.5 & ND & ND & ND & $8.24 \mathrm{E}-04$ & ND & BDL & BDL \\
\hline $5 \mathrm{H}-4$ & 39 & ND & ND & ND & $3.85 \mathrm{E}-04$ & ND & BDL & $\mathrm{BDL}$ \\
\hline $6 \mathrm{H}-4$ & 48.5 & ND & ND & ND & 2.37E-04 & ND & $\mathrm{BDL}$ & BDL \\
\hline
\end{tabular}

Note: $\mathrm{BDL}=$ below detection limit, $\mathrm{ND}=$ not determined. 
Table T7. Carbon, Hole U1316A.

\begin{tabular}{|c|c|c|c|c|}
\hline \multirow{2}{*}{$\begin{array}{l}\text { Core, section, } \\
\text { interval }(\mathrm{cm})\end{array}$} & \multirow{2}{*}{$\begin{array}{l}\text { Depth } \\
\text { (mbsf) }\end{array}$} & \multirow{2}{*}{$\begin{array}{l}\text { Mass } \\
(\mathrm{mg})\end{array}$} & \multicolumn{2}{|c|}{ Carbon (wt\%) } \\
\hline & & & Inorganic & $\mathrm{CaCO}_{3}$ \\
\hline \multicolumn{5}{|l|}{ 307-U1316A- } \\
\hline $1 \mathrm{H}-2,26-27$ & 1.76 & 12.2 & 2.3 & 18.9 \\
\hline $1 \mathrm{H}-4,26-27$ & 4.76 & 13.5 & 2.5 & 20.9 \\
\hline $2 \mathrm{H}-2,26-27$ & 9.06 & 11.0 & 2.0 & 16.5 \\
\hline $2 \mathrm{H}-4,26-27$ & 12.06 & 11.6 & 1.7 & 14.3 \\
\hline $3 \mathrm{H}-2,26-27$ & 18.56 & 17.5 & 1.9 & 16.2 \\
\hline $3 \mathrm{H}-5,26-27$ & 23.06 & 9.5 & 2.1 & 17.8 \\
\hline $3 \mathrm{H}-\mathrm{CC}, 8-9$ & 26.34 & 11.8 & 1.9 & 15.5 \\
\hline $4 \mathrm{H}-2,25-26$ & 28.05 & 22.5 & 2.2 & 17.9 \\
\hline $4 \mathrm{H}-5,25-26$ & 32.55 & 9.5 & 1.9 & 16.2 \\
\hline $5 \mathrm{H}-2,25-26$ & 37.55 & 13.0 & 1.7 & 14.5 \\
\hline $5 \mathrm{H}-5,25-26$ & 42.05 & 12.3 & 1.7 & 14.2 \\
\hline $5 \mathrm{H}-6,127-128$ & 44.57 & 9.1 & 3.1 & 25.6 \\
\hline $6 \mathrm{H}-2,27-28$ & 47.07 & 8.9 & 1.9 & 16.1 \\
\hline $6 \mathrm{H}-4,106-107$ & 50.86 & 17.5 & 7.3 & 60.6 \\
\hline $6 \mathrm{H}-5,35-36$ & 51.65 & 10.7 & 3.1 & 25.6 \\
\hline $6 \mathrm{H}-7,33-34$ & 54.63 & 13.8 & 7.0 & 58.0 \\
\hline 7H-1, 22-23 & 55.02 & 15.8 & 5.0 & 41.9 \\
\hline $8 \mathrm{H}-2,27-28$ & 65.16 & 13.1 & 3.4 & 28.0 \\
\hline $10 X-2,26-27$ & 77.56 & 14.3 & 2.7 & 22.3 \\
\hline $11 X-2,30-31$ & 80.10 & 12.1 & 3.0 & 25.2 \\
\hline $11 X-4,25-26$ & 83.05 & 10.5 & 3.2 & 26.4 \\
\hline $12 X-1,30-31$ & 83.60 & 14.2 & 3.3 & 27.1 \\
\hline $12 X-2,79-80$ & 85.59 & 19.0 & 2.8 & 23.6 \\
\hline $13 X-2,20-21$ & 89.50 & 16.2 & 2.8 & 23.0 \\
\hline $13 X-4,25-26$ & 92.55 & 16.8 & 2.5 & 20.9 \\
\hline $15 X-1,22-24$ & 94.52 & 11.1 & 6.0 & 49.9 \\
\hline $15 X-1,75-77$ & 95.05 & 13.3 & 3.0 & 24.8 \\
\hline $16 X-2,27-29$ & 100.77 & 11.7 & 3.1 & 25.4 \\
\hline $16 X-5,22-24$ & 105.22 & 12.1 & 2.1 & 17.6 \\
\hline $17 X-1,28-29$ & 108.88 & 15.7 & 4.0 & 33.0 \\
\hline $18 X-2,23-24$ & 114.03 & 19.3 & 4.0 & 33.6 \\
\hline $18 X-5,30-31$ & 118.60 & 13.0 & 3.6 & 29.8 \\
\hline $19 X-1,95-96$ & 119.25 & 10.6 & 4.8 & 39.9 \\
\hline $20 \times-2,48-49$ & 120.13 & 13.0 & 5.9 & 48.7 \\
\hline $21 X-2,23-24$ & 127.03 & 11.5 & 7.1 & 58.7 \\
\hline $21 X-4,23-24$ & 130.03 & 16.5 & 7.7 & 64.2 \\
\hline
\end{tabular}

Table T8. Contamination test results from the use of perfluorcarbon tracer and fluorescent microspheres, Holes U1316B and U1316C.

\begin{tabular}{lcccccc}
\hline Core, section & Depth (mbsf) & PFT-out & PFT-in & Catwalk & Drill fluid $\begin{array}{c}\text { Fluorescent } \\
\text { microspheres/cm }\end{array}$ \\
\hline 307-U1316B- & & & & & & \\
1H-3 & $4.85-4.90$ & - & ND & - & - & 0 \\
$2 \mathrm{H}-3$ & $10.35-10.40$ & - & ND & - & - & 0 \\
3H-3 & $19.85-19.90$ & - & ND & - & - & 0 \\
4 H-3 & $29.35-29.40$ & - & ND & - & - & 0 \\
5H-3 & $38.85-38.90$ & - & ND & - & - & 0 \\
6H-3 & $48.35-48.40$ & - & ND & - & - & 42 \\
307-U1316C- & & & & & & \\
4R-4 & $74.20-74.25$ & Positive & ND & ND & Positive & 0 \\
5R-3 & $82.30-82.35$ & Positive & ND & - & - & 0 \\
6R-3 & $90.85-90.90$ & - & ND & - & - & 0 \\
7R-2 & $99.95-100.00$ & ND & ND & - & - & 0 \\
8R-2 & $109.65-109.70$ & Positive & ND & - & - & 21 \\
9R-4 & $122.35-122.40$ & Positive & ND & & & 17 \\
11R-3 & $137.75-137.80$ & Positive & ND & - & - & 0 \\
\hline
\end{tabular}

Notes: PFT-out $=$ sample from the core periphery (interface between liner and core), PFT-in = sample from the inner core section between center and periphery. $-=$ no sample taken, ND $=$ not detected. ${ }^{*}=50 \%$ porosity assumed for all samples. 
Table T9. Composite depth offsets, Holes, U1316A, U1316B, and U1316C.

\begin{tabular}{|c|c|c|c|c|}
\hline Core & $\begin{array}{l}\text { Length } \\
(\mathrm{m})\end{array}$ & $\begin{array}{l}\text { Depth } \\
\text { (mbsf) }\end{array}$ & $\begin{array}{l}\text { Offset } \\
(\mathrm{m})\end{array}$ & $\begin{array}{l}\text { Depth } \\
\text { (mbsf) }\end{array}$ \\
\hline \multicolumn{5}{|c|}{ 307-U1316A- } \\
\hline $1 \mathrm{H}$ & 7.3 & 0.0 & 0.00 & 0.00 \\
\hline $2 \mathrm{H}$ & 9.5 & 7.3 & 1.20 & 8.50 \\
\hline $3 \mathrm{H}$ & 9.5 & 16.8 & 1.27 & 18.07 \\
\hline $4 \mathrm{H}$ & 9.5 & 26.3 & 2.07 & 28.37 \\
\hline $5 \mathrm{H}$ & 9.5 & 35.8 & 1.95 & 37.75 \\
\hline $6 \mathrm{H}$ & 9.5 & 45.3 & 2.75 & 48.05 \\
\hline $7 \mathrm{H}$ & 9.5 & 54.8 & 4.32 & 59.12 \\
\hline $8 \mathrm{H}$ & 2.0 & 64.3 & 4.32 & 68.62 \\
\hline $9 X$ & 9.5 & 66.3 & 4.32 & 70.62 \\
\hline $10 x$ & 2.5 & 75.8 & 5.36 & 81.16 \\
\hline $11 x$ & 5.0 & 78.3 & 5.36 & 83.66 \\
\hline $12 \mathrm{X}$ & 4.5 & 83.3 & 6.75 & 90.05 \\
\hline $13 x$ & 6.0 & 87.8 & 6.75 & 94.55 \\
\hline $14 X$ & 0.5 & 93.8 & 6.75 & 100.55 \\
\hline $15 \mathrm{X}$ & 4.7 & 94.3 & 8.04 & 102.34 \\
\hline $16 X$ & 9.6 & 99.0 & 8.04 & 107.04 \\
\hline $17 X$ & 3.7 & 108.6 & 9.29 & 117.89 \\
\hline $18 \mathrm{X}$ & 6.0 & 112.3 & 11.57 & 123.87 \\
\hline $19 x$ & 0.5 & 118.3 & 11.57 & 129.87 \\
\hline $20 x$ & 6.5 & 118.8 & 11.30 & 130.10 \\
\hline $21 X$ & 8.7 & 125.3 & 10.55 & 135.85 \\
\hline \multicolumn{5}{|c|}{ 307-U1316B- } \\
\hline $1 \mathrm{H}$ & 5.5 & 0.0 & 0.25 & 0.25 \\
\hline $2 \mathrm{H}$ & 9.5 & 5.5 & 0.80 & 6.30 \\
\hline $3 \mathrm{H}$ & 9.5 & 15.0 & 0.60 & 15.60 \\
\hline $4 \mathrm{H}$ & 9.5 & 24.5 & 0.26 & 24.76 \\
\hline $5 \mathrm{H}$ & 9.5 & 34.0 & 0.50 & 34.50 \\
\hline $6 \mathrm{H}$ & 9.5 & 43.5 & 0.56 & 44.06 \\
\hline $7 \mathrm{H}$ & 6.3 & 53.0 & 0.14 & 53.14 \\
\hline $8 \mathrm{H}$ & 0.2 & 59.3 & 0.14 & 59.44 \\
\hline \multicolumn{5}{|c|}{ 307-U1316C- } \\
\hline $1 \mathrm{R}$ & 9.2 & 40.0 & 0.00 & 40.00 \\
\hline $2 \mathrm{R}$ & 9.6 & 49.2 & 6.99 & 56.33 \\
\hline $3 \mathrm{R}$ & 9.6 & 58.8 & 7.18 & 66.12 \\
\hline $4 \mathrm{R}$ & 9.6 & 68.4 & 7.18 & 75.72 \\
\hline $5 \mathrm{R}$ & 9.6 & 78.0 & 7.66 & 85.80 \\
\hline $6 \mathrm{R}$ & 9.6 & 87.6 & 7.86 & 95.60 \\
\hline $7 \mathrm{R}$ & 9.7 & 97.2 & 9.35 & 106.69 \\
\hline $8 \mathrm{R}$ & 9.7 & 106.9 & 9.35 & 116.39 \\
\hline $9 \mathrm{R}$ & 9.6 & 116.6 & 10.26 & 127.00 \\
\hline $10 \mathrm{R}$ & 7.2 & 126.2 & 0.00 & - \\
\hline $11 \mathrm{R}$ & 9.7 & 133.4 & 0.00 & 143.80 \\
\hline
\end{tabular}

Note: $-=$ no data available. 
Table T10. Splice tie points, Site U1316.

\begin{tabular}{|c|c|c|c|c|c|c|}
\hline \multirow{2}{*}{$\begin{array}{l}\text { Hole, core, section, } \\
\text { interval }(\mathrm{cm})\end{array}$} & \multicolumn{2}{|c|}{ Depth } & & \multirow{2}{*}{$\begin{array}{l}\text { Hole, core, section, } \\
\text { interval }(\mathrm{cm})\end{array}$} & \multicolumn{2}{|c|}{ Depth } \\
\hline & (mbsf) & (mcd) & & & (mbsf) & (mcd) \\
\hline $307-$ & & & & $307-$ & & \\
\hline U1316A-1H-5, 70 & 6.67 & 6.67 & Tie to & U1316B-2H-1, 35.5 & 5.87 & 6.67 \\
\hline U1316B-2H-2, 140 & 8.40 & 9.20 & Tie to & U1316A-2H-1, 73.5 & 8.00 & 9.20 \\
\hline U1316A-2H-6, 50 & 14.87 & 16.07 & Tie to & U1316B-3H-1, 45.5 & 15.47 & 16.07 \\
\hline U1316B-3H-2, 124.5 & 17.74 & 18.34 & Tie to & U1316A-3H-1, 28.5 & 17.07 & 18.34 \\
\hline U1316A-3H-6, 120 & 24.96 & 26.23 & Tie to & U1316B-4H-1, 147 & 25.97 & 26.23 \\
\hline U1316B-4H-3, 90 & 28.40 & 28.66 & Tie to & U1316A-4H-1, 30 & 26.59 & 28.66 \\
\hline U1316A-4H-5, 105 & 33.02 & 35.09 & Tie to & U1316B-5H-1, 58.5 & 34.59 & 35.09 \\
\hline U1316B-5H-3, 40 & 37.40 & 37.90 & Tie to & U1316A-5H-1, 15 & 35.95 & 37.90 \\
\hline U1316A-5H-6, 110 & 44.40 & 46.35 & Tie to & U1316B-6H-2, 78.5 & 45.79 & 46.35 \\
\hline U1316B-6H-5, 10 & 50.10 & 50.66 & Tie to & U1316A-6H-2, 125 & 47.91 & 50.66 \\
\hline U1316A-6H-6, 115 & 53.50 & 56.25 & Tie to & U1316B-7H-3, 68.3 & 56.11 & 56.25 \\
\hline U1316B-7H-5, 7 & 57.96 & 58.10 & Tie to & U1316C-2R-2, 25.4 & 50.97 & 58.10 \\
\hline U1316C-2R-3, 95 & 53.12 & 60.25 & Tie to & U1316A-7H-1, 112 & 55.93 & 60.25 \\
\hline U1316A-7H-2, 145 & 57.75 & 62.07 & Append to & U1316C-3R-1, 0 & 58.80 & 66.12 \\
\hline U1316C-3R-4, 84.3 & 63.64 & 70.96 & Append to & U1316C-4R-1, 0 & 68.40 & 75.72 \\
\hline U1316C-4R-6, 52.2 & 76.42 & 83.74 & Append to & U1316A-11X-1, 0 & 78.29 & 83.65 \\
\hline U1316A-11X-3, 30 & 81.06 & 86.42 & Tie to & U1316C-5R-1, 60.5 & 78.62 & 86.42 \\
\hline U1316C-5R-5, 25 & 83.75 & 91.55 & Tie to & U1316A-12X-1, 150 & 84.80 & 91.55 \\
\hline U1316A-12X-2, 80 & 85.60 & 92.35 & Append to & U1316A-13X-1, 0 & 87.80 & 94.55 \\
\hline U1316A-13X-4, 45 & 92.75 & 99.50 & Tie to & U1316C-6R-4, 40 & 91.50 & 99.50 \\
\hline U1316C-6R-6, 119.6 & 95.32 & 103.32 & Append to & U1316A-16X-1, 0 & 99.00 & 107.04 \\
\hline U1316A-16X-6, 60 & 106.84 & 114.88 & Tie to & U1316C-7R-6, 68.5 & 105.39 & 114.88 \\
\hline U1316C-7R-7, 70 & 106.90 & 116.39 & Append to & U1316C-8R-1, 0 & 106.90 & 116.39 \\
\hline U1316C-8R-6, 55 & 114.95 & 124.44 & Tie to & U1316A-18X-1, 95 & 112.87 & 124.44 \\
\hline U1316A-18X-6, 145 & 117.71 & 129.28 & Tie to & U1316C-9R-2, 77 & 118.88 & 129.28 \\
\hline U1316C-9R-7, 25 & 125.85 & 136.25 & Tie to & U1316A-21X-1, 40 & 125.70 & 136.25 \\
\hline U1316A-21X-5, 80 & 132.10 & 142.65 & Append to & U1316C-11R-1, 0 & 133.40 & 143.80 \\
\hline U1316C-11R-6, 145 & 142.35 & 152.75 & & & & \\
\hline
\end{tabular}

Table T11. Logging operations, Hole U1316A.

\begin{tabular}{ccl}
\hline $\begin{array}{c}\text { Date } \\
\text { (May 2005) }\end{array}$ & $\begin{array}{c}\text { Local time } \\
(\mathrm{h})\end{array}$ & \\
\hline 1 & 2300 & \multicolumn{1}{c}{ Comments } \\
2 & 0100 & $\begin{array}{l}\text { Hole preparation complete, rig up short version of triple combo (HNGS-APS-HLDS) } \\
\text { Runte with short version of triple combo }\end{array}$ \\
2 & 0230 & $\begin{array}{l}\text { Encountered obstruction 15 m below pipe } \\
2\end{array}$ \\
2 & & $\begin{array}{l}\text { Start pumping and pulling up and down (10 m) the pipe without success } \\
\text { Abort logging operation in Hole U1316A }\end{array}$ \\
2 & 0430 & $\begin{array}{l}\text { Pull tools out of hole and rig down } \\
\text { End of logging operation }\end{array}$ \\
\hline
\end{tabular}

Notes: Drillers total depth $=1093 \mathrm{mbrf}$, water depth $=948 \mathrm{~m}$, end of pipe $=30 \mathrm{mbsf}$, total depth $=134 \mathrm{mbsf}$. Triple combo $=$ triple combination, HNGS = Hostile Environment Natural Gamma Ray Sonde, APS = Accelerator Porosity Sonde, HLDS = Hostile Environment Litho-Density Sonde. 
Table T12. Logging operations, Hole U1316C.

\begin{tabular}{ccl}
\hline $\begin{array}{c}\text { Date } \\
\text { (May 2005) }\end{array}$ & $\begin{array}{c}\text { Local } \\
\text { time }(\mathrm{h})\end{array}$ & \multicolumn{1}{c}{ Comments } \\
\hline 8 & 0300 & Hole preparation complete, rig up triple combo (HNGS-APS-HLDS-DIT) \\
8 & 0515 & Run into hole with triple combo \\
8 & 0635 & Uplog with triple combo at $900 \mathrm{ft} / \mathrm{h}$ from total depth \\
8 & 0715 & Pull tools out of hole and rig down \\
8 & 0815 & Rig up FMS-sonic (SGT-DSI-GPIT-FMS) \\
8 & 0900 & Run into hole with FMS-sonic \\
8 & 1030 & First pass with FMS-sonic at $900 \mathrm{ft} / \mathrm{h}$ from total depth \\
8 & 1050 & Going down for main pass \\
8 & 1105 & Uplog with FMS-sonic at $900 \mathrm{ft} / \mathrm{h}$ from total depth \\
8 & 1135 & Pull tools out of hole and rig down \\
8 & 1215 & Clear rig floor of logging tools, sheaves, and wireline \\
8 & 1330 & End of logging operation \\
\hline
\end{tabular}

Notes: Drillers total depth $=1098 \mathrm{mbrf}$, water depth $=943 \mathrm{~m}$, end of pipe $=57 \mathrm{mbsf}$, total depth $=143 \mathrm{mbsf}$. Triple combo $=$ triple combination, HNGS = Hostile Environment Natural Gamma Ray Sonde, APS = Accelerator Porosity Sonde; HLDS = Hostile Environment Litho-Density Sonde, DIT = Dual Induction Tool, SGT = Scintillation Gamma Ray Tool, DSI = Dipole Sonic Imager, GPIT = General Purpose Inclinometry Tool, FMS = Formation MicroScanner. 